\title{
REBAIXAMENTO DINÂMICO EM RESERVATÓRIOS DE USINAS HIDRELÉTRICAS: ESTUDO DE CASO APLICADO À BACIA DO RIO IGUAÇU
}

Carla Ramos Rodrigues Mori

DISSERTAÇÃO DE MESTRADO EM ENGENHARIA ELÉTRICA DEPARTAMENTO DE ENGENHARIA ELÉTRICA

FACULDADE DE TECNOLOGIA 
UNIVERSIDADE DE BRASÍLIA

FACULDADE DE TECNOLOGIA

DEPARTAMENTO DE ENGENHARIA ELÉTRICA

\section{REBAIXAMENTO DINÂMICO EM RESERVATÓRIOS DE USINAS HIDRELÉTRICAS: ESTUDO DE CASO APLICADO À BACIA DO RIO IGUAÇU}

CARLA RAMOS RODRIGUES MORI

ORIENTADOR: FRANCISCO DAMASCENO FREITAS

DISSERTAÇÃO DE MESTRADO EM ENGENHARIA ELÉTRICA

PUBLICAÇÃO: PPGEE.DM - 633/2016

BRASÍLIA/DF: JUNHO - 2016 


\title{
UNIVERSIDADE DE BRASÍLIA \\ FACULDADE DE TECNOLOGIA \\ DEPARTAMENTO DE ENGENHARIA ELÉTRICA
}

\begin{abstract}
REBAIXAMENTO DINÂMICO EM RESERVATÓRIOS DE USINAS HIDRELÉTRICAS: ESTUDO DE CASO APLICADO À BACIA DO RIO IGUAÇU
\end{abstract}

\section{CARLA RAMOS RODRIGUES MORI}

DISSERTAÇÃO DE MESTRADO SUBMETIDA AO PROGRAMA DE PÓS-GRADUAÇÃo EM ENGENHARIA ELÉTRICA DA UNIVERSIDADE DE BRASÍLIA, COMO PARTE DOS REQUISITOS NECESSÁRIOS PARA OBTENÇÃO DO GRAU DE MESTRE.

APROVADA POR:

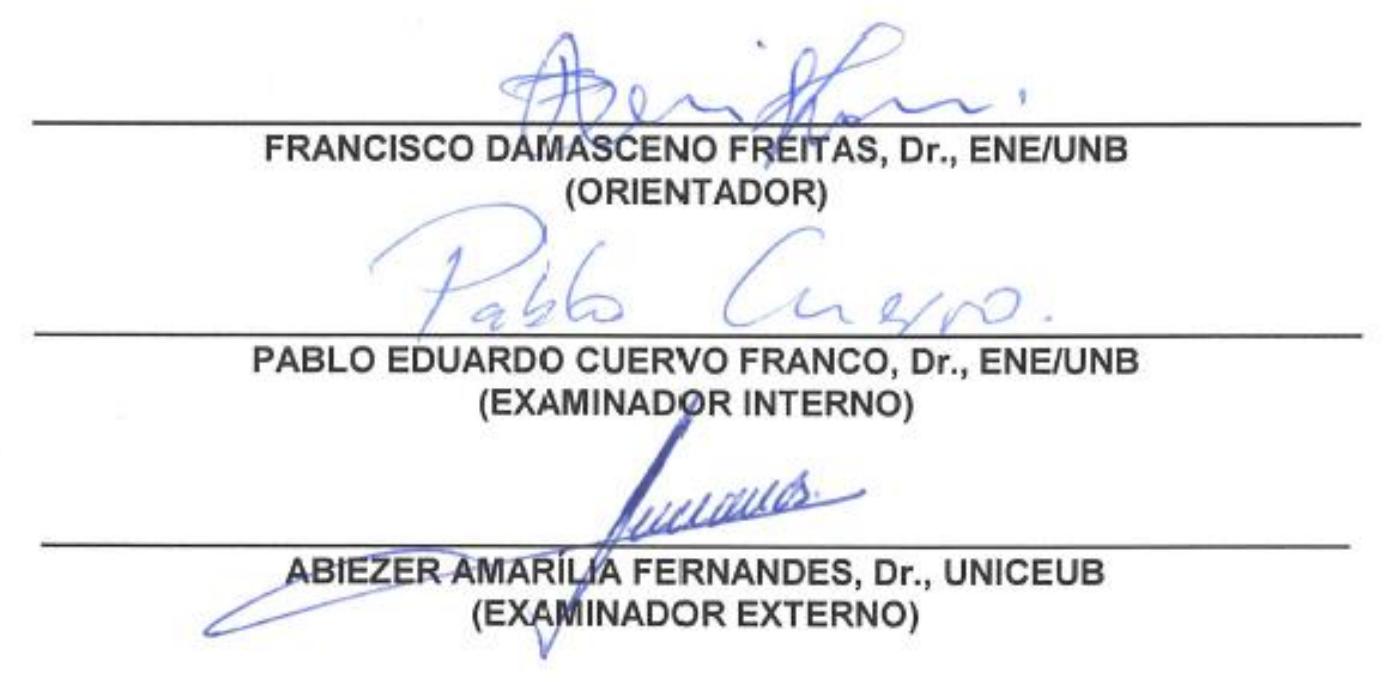

Brasília, 30 de junho de 2016. 


\section{FICHA CATALOGRÁFICA}

\section{MORI, CARLA RAMOS RODRIGUES}

Rebaixamento Dinâmico em Reservatórios de Usina Hidrelétrica: Estudo de Caso Aplicado à Bacia do Rio Iguaçu [Distrito Federal] 2016.

xx,70p., 210 x 297 mm (ENE/FT/UnB, Mestre, Dissertação de Mestrado, 2016)

Universidade de Brasília. Faculdade de Tecnologia. Departamento de Engenharia Elétrica.

1.Rebaixamento Dinâmico

2.Vazão defluente

3. HidroExpert

4.Bacia do Rio Iguaçu

I. ENE/FT/UnB

II. Título (série)

\section{REFERÊNCIA BIBLIOGRÁFICA}

MORI, C. R. R. (2016). Rebaixamento Dinâmico em Reservatórios de Usina Hidrelétrica:

Estudo de Caso Aplicado à Bacia do Rio Iguaçu. Dissertação de Mestrado em Engenharia Elétrica, Publicação PPGEE.DM-633/2016, Departamento de Engenharia Elétrica, Universidade de Brasília, Brasília, DF, 70p.

\section{CESSÃO DE DIREITOS}

AUTOR: Carla Ramos Rodrigues Mori.

TÍTULO: Rebaixamento Dinâmico em Reservatórios de Usina Hidrelétrica: Estudo de Caso Aplicado à Bacia do Rio Iguaçu.

GRAU: Mestre

ANO: 2016

É concedida à Universidade de Brasília permissão para reproduzir cópias desta dissertação de mestrado e para emprestar ou vender tais cópias somente para propósitos acadêmicos e científicos. O autor reserva outros direitos de publicação e nenhuma parte dessa dissertação de mestrado pode ser reproduzida sem autorização por escrito do autor.

Carla Ramos Rodrigues Mori

Universidade de Brasília-UnB

Campus Darcy Ribeiro

Faculdade de Tecnologia - FT

Departamento de Engenharia Elétrica

Brasília - DF

CEP: 70910-900 
Ao meu esposo Leonardo Mitsuhiro e meu filho Victor Hugo

Hideharu e aos meus pais, Orlindo e Maria do Carmo, DEDICO. iv 


\section{AGRADECIMENTOS}

Ao meu esposo, que me incentivou, apoiou e compreendeu todos os esforços que tiveram de ser realizados, para que este objetivo fosse concluído.

Ao meu orientador, Professor Dr. Francisco Damasceno Freitas, pela confiança em mim depositada, pela amizade e pela orientação.

Ao meu amigo e gerente João Odilon, pelo incentivo e apoio incondicional para que este objetivo fosse concluído.

Ao professor, Dr. Marcelo Cicogna, que me apoiou com o uso da ferramenta HydroExpert onde sou eternamente grata.

Ao meu amigo Guilherme Guilhon, pelos incentivos e apoio para o uso da ferramenta HydroExpert.

Aos colegas de trabalho do ONS, pelo incentivo e apoio para a conclusão deste trabalho.

Aos familiares e amigos, pela compreensão e pelo apoio. 


\section{RESUMO}

A utilização de diversos modelos de previsão de estimativas futuras torna-se necessária para realização de antecipação do conhecimento de vazões e níveis d'água em um reservatório. Estas grandezas operativas estão diretamente associadas ao atendimento da programação de geração e de diversas restrições operativas hidráulicas como, por exemplo, os níveis máximos operativos dos reservatórios, as vazões defluentes máximas e mínimas, restrições à segurança de barragem (volume de espera, nível máximo operativo, nível máximo maximorum, defluência máxima) e os limites existentes para vazões defluentes, níveis de montante e de jusante.

Esta dissertação tem como objetivo o estudo de caso relacionado com a regularização dinâmica dos reservatórios de hidrelétricas. O principal alvo é a antecipação do rebaixamento de um reservatório e obter um espaço vazio no reservatório, a fim de alocar um volume elevado de água. O software HydroExpert é utilizado para realizar todas a simulações necessárias para o estudo. $\mathrm{O}$ problema é modelado de acordo com as características de um sistema prático e simuladas para algumas condições operacionais. As experiências com o estudo são avaliadas por meio de simulações considerando usinas da bacia do rio Iguaçu. Os resultados dos estudos indicam a eficácia da metodologia para melhorar as ações de períodos hidrológicos críticos que possam ocorrer em condições operacionais.

Através das simulações, ficam demonstradas as diversas aplicações de um modelo de simulação da operação hidráulica de reservatórios, baseadas no aplicativo HydroExpert. Verifica-se a eficácia deste aplicativo para realização de rebaixamento dinâmico e, portanto, como importante suporte, principalmente, para ações que envolvam operação em tempo real.

PALAVRAS-CHAVE: rebaixamento dinâmico de reservatórios, defluências, cheias, Sistema Interligado Nacional, Bacia do rio Iguaçu. 


\section{ABSTRACT}

Several prediction models for future estimates are usually used as a tool to anticipate adequate flow and water levels in reservoirs. This operational quantities are directly associated with customer service of the generation schedule and to various hydraulic operating restriction. We can cite for instance, the maximum operating level of the reservoirs, maximum and minimum flowing downs rates, maximum and minimum restrictions on the safety of dam (say expected volume, maximum operative level, maximum maximorum level, maximum flowing down rate) and existing limits for flowing down rates, levels of upstream and downstream.

This dissertation presents a case study related to the dynamic regularization of hydropower reservoirs. The main purpose is to anticipate the drawdown of a reservoir and obtain an empty space in the reservoir in order to allocate a high water volume. The software HydroExpert is used to perform all simulations required for the study. The problem is modeled according to the characteristics of a practical system and simulated for some operational conditions. The experiments on the study are assessed for two Iguaçu river basin hydropowers. The study results indicate the efficacy of the methodology to improve actions for critical hydrological periods which are feasible of occurring under operational conditions.

Finally, thereby demonstrating, applications of a simulation model of the hydraulic operation of the reservoirs, which is used by the system HydroExpert to support generation agents and ONS (Brazilian System Operator), giving support mainly for real-time operation actions.

INDEX TERMS: regularization dynamic of hyropower reservoirs, Iguaçu river basin hydropowers, Brazilian System Operator. 


\section{SUMÁRIO}

$\begin{array}{ll}\text { INTRODUÇÃO } & 1\end{array}$

1.1. CONTEXTUALIZAÇÃO DO TEMA

1.2. MOTIVAÇÃO 2

1.3. OBJETIVO 3

1.4. ORGANIZAÇÃO DO TEXTO 3

REVISÃO BIBLIOGRÁFICA 5

FUNDAMENTOS SOBRE REBAIXAMENTO DE RESERVATÓRIOS

3.3 REBAIXAMENTO DINÂMICO DE RESERVATÓRIOS 10

3.4 CÁLCULO DO VOLUME EXCEDENTE

3.5 CÁLCULO DO VOLUME VAZIO

3.6 VAZÃO DEFLUENTE PARA REBAIXAMENTO E RECUPERAÇÃO 14

3.7 VAZÃO DEFLUENTE PARA ATENDIMENTO DA MÁXIMA NATURAL 15

3.8 CARACTERIZAÇÃO DA BACIA DO RIO IGUAÇU 16

3.9 RESTRIÇÕES HIDRÁULICAS EXISTENTES NA BACIA DO RIO IGUAÇU 18

3.9.1 UHE Foz do Areia 19

3.9.2 UHE Segredo 19

3.9.3 UHE Salto Santiago 20

3.9.4 UHE Salto Osório 20

3.9.5 UHE Salto Caxias 20

3.10 Volume excedente e NA máximo maximorum 21

3.11 Volume útil e NA máximo operacional 22

3.12 Volume morto e NA mínimo operacional 22

SIMULADOR HIDRÁULICO HYDROEXPERT

4.1. INTRODUÇÃO

4.2. O APROVEITAMENTO HIDROELÉTRICO SIMULADO. 24

4.3. SOLUÇÃO INICIAL PARA A PROGRAMAÇÃO DE DEFLUENCIAS. 25

APRESENTAÇÃO E ANÁLISE DE RESULTADOS

5.1. A BACIA SIMULADA 27

5.1. ANÁLISE DA SEMANA OPERATIVA DE 01/02 A 05/02/2015 COM VOLUME EXCEDENTE MAIOR QUE O VOLUME VAZIO.

5.1. ANÁLISE DA SEMANA OPERATIVA DE 08/02 A 13/02/2015 COM TODA BACIA DO IGUAÇU ACIMA DE

$80 \%$ VU 32

5.2. ANÁLISE DA SEMANA OPERATIVA DE 13/07 A 17/07/15 COM PREVISÃO DE ALTAS PRECIPITAÇÕES 37

5.3. ANÁLISE DA SEMANA OPERATIVA DE 07/12 A 12/12/2015 COM INDISPONIBILIDADE DE UMA UNIDADE GERADORA NA UHE FOZ DO AREIA.

CONCLUSÕES E PROPOSTAS DE TRABALHOS FUTUROS

REFERÊNCIAS BIBLIOGRÁFICAS

ENTRADA DA ROTINA DO HYDROEXPERT 


\section{LISTA DE FIGURAS}

Figura 3.1 - Representação esquemático hidráulico para rebaixamento hidráulico

10

Figura 3.2 - Ilustração das trajetórias de vazões no cálculo do rebaixamento e recuperação dinâmicos os reservatórios num cenário ainda sem vertimento. 10

Figura 3.3 - Representação esquemática de dois reservatórios incluindo as variáveis.

Figura 3.4 - Localização dos principais aproveitamentos hidráulicos existentes na bacia do rio Iguaçu

Figura 3.5 - Diagrama esquemático do sistema de aproveitamento hidrelétrico da bacia do rio Iguaçu.

Figura 3.6 - Restrições operativas de um aproveitamento.

Figura 3.7 - Esquema NA máximo maximorum.

Figura 3.8 - Esquema NA máximo operacional. .22

Figura 3.9 - Esquema NA mínimo operacional.

Figura 5.1 - Diagrama esquemático da bacia do rio Iguaçu.

Figura 5.2 - Indicação do volume excedente previsto no horizonte de previsão de afluências. .28

Figura 5.3 - Indicações da vazão na abertura do vertedouro da UHE Foz do Areia .29

Figura 5.4 - Indicações da vazão na abertura do vertedouro da UHE Segredo. . .29

Figura 5.5 -Indicações da vazão na abertura do vertedouro da UHE Salto Santiago .30

Figura 5.6 - Indicações da vazão na abertura do vertedouro da UHE Salto Osório. .30

Figura 5.7 - Indicações da vazão na abertura do vertedouro da UHE Salto Caxias.

Figura 5.8 - Armazenamento dos reservatórios .32

Figura 5.9 - Vazão do vertimento da UHE Foz do Areia .32

Figura 5.10 - Vazão do vertimento da UHE Segredo. .33

Figura 5.11 - Vazão do vertimento da UHE Salto Santiago. .33 
Figura 5.13 - Vazão do vertimento da UHE Salto Caxias

Figura 5.14- Indicação do volume excedente previsto no horizonte de previsão de afluências. .34

Figura 5.15- Indicação do rebaixamento dinâmico de 48 horas .35

Figura 5.16- Indicações da vazão do aumento do vertimento da UHE Foz do Areia .36

Figura 5.17- Indicações da vazão do aumento do vertimento da UHE Segredo. .36

Figura 5.18- Armazenamento dos reservatórios. .37

Figura 5.19- Indicações da vazão na abertura do vertedouro da UHE Foz do Areia .38

Figura 5.20 - Indicações de vazão na abertura do vertedouro da UHE Salto Santiago. .38

Figura 5.21- Armazenamento dos reservatórios. .39

Figura 5.22 - Programação de geração da UHE Foz do Areia.. 39

Figura 5.23- Programação de defluência/vertimento da UHE Foz do Areia 40

Figura 5.24- Programação de geração da UHE Segredo.

Figura 5.25- Programação de defluência/vertimento da UHE Segredo. .40

Figura 5.26- Programação de geração da UHE Salto Santiago. . .41

Figura 5.27- Programação de defluência/vertimento da UHE Salto Santiago... 41

Figura 5.28- Programação de geração da UHE Salto Osório. 41

Figura 5.29- Programação de defluência/vertimento da UHE Salto Osório. .42

Figura 5.30- Programação de geração da UHE Salto Caxias. 42

Figura 5.31- Programação de defluência/vertimento da UHE Salto Caxias.

Figura 5.32- Indicação do rebaixamento dinâmico das 100 horas

Figura 5.33- Programação de geração da UHE Foz do Areia .44

Figura 5.34- Programação de defluência da UHE Foz do Areia.. . .44

Figura 5.35- Programação de vertimento da UHE Foz do Areia. .45

Figura 5.36- Programação de geração da UHE Segredo. . .45 
Figura 5.37- Programação de defluência da UHE Segredo. .45

Figura 5.38- Programação de vertimento da UHE Segredo.. . .46 


\section{LISTA DE TABELAS}

Tabela 3.1 - Principais características dos aproveitamentos da bacia do rio Iguaçu..................................17

Tabela 5.2 - Tabela comparativa com indisponibilidade de unidades geradoras...................................44 


\section{LISTA DE QUADROS}

Quadro A.1 - Caixa de entrada do aplicativo HydroExpert.

Quadro A.2 - Caixa de entrada do aplicativo HydroExpert do Assistente Rebaixamento/Recuperação

Dinâmicos.....

. .53 


\section{LISTA DE SÍMBOLOS}

$t_{\text {ini }}^{e x} \quad$ Índice do intervalo inicial de tempo do horizonte do estudo associado ao cenário de vazões para o qual se quer determinar o volume em excesso.

$T^{e x} \quad$ Número de intervalos de tempos do cenário de vazões para o qual se quer determinar o volume em excesso.

$t_{i n i}^{r r} \quad$ Índice do intervalo inicial de tempo do horizonte do estudo associado ao cenário de rebaixamento e recuperação dinâmicos.

$T^{r r} \quad$ Número de intervalos do horizonte de rebaixamento.

$\hat{y}_{i, t} \quad$ Previsão de vazão incremental afluente horária.

$\hat{y}_{j, t} \quad$ Previsão de vazão incremental afluente horária para a área incremental entre os aproveitamentos.

$\hat{d}_{j, t} \quad$ Previsão da vazão de desvio entre os aproveitamentos.

$t v_{i} \quad$ Tempo de viagem entre os aproveitamentos.

$\Delta t \quad$ Duração do intervalo de discretização do horizonte de estudo.

$\hat{q}_{i, t} \quad$ Estimativa da vazão turbinada no reservatório $i$, durante o intervalo $t$.

$\hat{d}_{i, t} \quad$ Estimativa da vazão de desvio, associada ao reservatório $i$, durante o intervalo $t$.

$\hat{u}_{m, t} \quad$ Vazão defluente do aproveitamento do índice $m$, durante o intervalo $t\left[\mathrm{~m}^{3} / \mathrm{s}\right]$.

$f_{c n} \quad$ Fator utilizado para a conversão da unidade de vazão $\left[\mathrm{m}^{3} / \mathrm{s}\right]$ para a unidade de volume $\left[\mathrm{hm}^{3}\right]$.

$t v_{m} \quad$ Tempo de viagem da vazão defluente entre $m$ e $i[\mathrm{~h}]$.

$\hat{a}_{i, t}$ Estimativa da vazão afluente do aproveitamento $i$, durante o intervalo $t$, considerando tempo de viagem.

$\Omega_{i} \quad$ Conjunto de índice dos aproveitamentos diretamente a montante de $i$. 


\section{GLOSSÁRIO}

$\begin{array}{ll}\text { BDT } & \text { Base de Dados Técnicos } \\ \text { CMO } & \text { Custo Marginal da Operação } \\ \text { COPEL } & \text { Companhia Paranaense de Energia } \\ \text { ENSO } & \text { El-nino }- \text { Oscilação Sul } \\ \text { GBM } & \text { Governador Bento Munhoz } \\ \text { GJR } & \text { Governador José Richa } \\ \text { GNB } & \text { Governador Ney Braga } \\ \text { NA } & \text { Nível de armazenamento } \\ \text { ONS } & \text { Operador Nacional do Sistema Elétrico } \\ \text { SEP } & \text { Sistema Elétrico de Potência } \\ \text { SIN } & \text { Sistema Interligado Nacional } \\ \text { SPEC } & \text { Sistema para Estudos de Prevenção de Cheias } \\ \text { TR } & \text { Tempo de recorrência } \\ \text { UHE } & \text { Usina Hidrelétrica } \\ \text { UnB } & \text { Universidade de Brasília } \\ \text { VU } & \text { Volume útil }\end{array}$




\section{CAPÍTULO 1}

\section{INTRODUÇÃO}

\subsection{CONTEXTUALIZAÇÃO DO TEMA}

Diante do cenário energético Brasileiro atual (ONS, 2014) têm-se observado uma grande preocupação com relação ao armazenamento das usinas hidráulicas e a crescente utilização de outras fontes alternativas de geração de energia elétrica

A deficiência de chuva em algumas regiões do Brasil leva a restrições operativas de usinas hidrelétricas, em razão do baixo volume dos reservatórios. Este fato causa impactos energéticos negativos à operação do Sistema Interligado Nacional (SIN). Por consequência, causa aumento do custo marginal de operação (CMO) do sistema, aumento no despacho de usinas termelétricas e, em alguns casos, chega a comprometer a segurança elétrica do sistema. Tais situações, evidentemente, são indesejáveis.

Outra preocupação com relação às bacias hidrográficas brasileiras está relacionada ao controle de cheias. Este fato leva a estudos sobre os períodos hidrológicos. Pois, havendo uma grande quantidade de chuvas (vazão natural), torna-se necessário realizar possível rebaixamento do reservatório afetado para amenizar uma cheia e até mesmo grandes catástrofes.

Contudo, além de garantir a integridade da própria barragem, existe a questão da inundação de áreas à jusante desta. Este problema pode ocorrer sempre que a vazão defluente ultrapassar um determinado limite crítico (denominado vazão de restrição), em geral, muito inferior à vazão máxima para a qual o vertedor foi projetado. Esta restrição à vazão defluente, às vezes, sequer existe quando a barragem está em fase de projeto.

Ocorrendo o desenvolvimento de vale à jusante da barragem, cria-se uma dramaticidade com relação a eventuais extravasamentos fluviais. Considerando o objetivo de geração de energia, este é um processo que força o órgão responsável pela operação do aproveitamento a considerar o duplo propósito de gerar energia e controlar cheias ao mesmo tempo. Mas, infelizmente trata-se de objetivos conflitantes. Ou seja, para gerar energia mantém-se o reservatório o mais cheio possível de forma a prover água e queda durante futuras estiagens. No entanto, para controlar cheias é necessário manter o reservatório vazio para garantir espaço capaz de laminar os grandes picos de descarga (Kelman, 1987). 
Atualmente, apesar do seu principal objetivo ser gerar energia elétrica, os empreendimentos hidrelétricos podem e devem, quando necessário, exercer o controle de cheias. Sendo que, além de objetivar a manutenção da integridade da própria barragem no caso de uma cheia, outro papel primordial da operação de hidrelétricas é prevenir as cheias em pontos à jusante da barragem. A prevenção pode ser efetuada a partir da fixação de limites de descargas. Neste caso, impõem-se restrições de vazão máxima, preservando assim cidades, rodovias, ferrovias e quaisquer locais de interesse socioeconômico (Diniz, 2002).

O setor elétrico tem adotado o termo vazão natural para identificar a vazão que ocorreria em uma seção do rio, caso não houvesse as ações antrópicas na sua bacia contribuinte. Outro termo utilizado é o de vazão afluente. Mas, este serve para caracterizar a vazão que chega a um aproveitamento hidroelétrico ou estrutura hidráulica, que é influenciada pelas obras de regularização e demais ações antrópicas porventura existentes na bacia hidrográfica (ONS, 2014).

A vazão afluente a um aproveitamento é normalmente calculada pelo balanço hídrico do seu reservatório, correspondendo ao balanço das entradas e saídas de água no seu interior, consideradas as variações efetivas de acumulação.

A vazão natural em uma seção de um rio cuja bacia contribuinte está sujeita ao efeito das ações antrópicas é obtida por meio de um processo de reconstituição. Este processo considera as vazões afluentes e defluentes observadas nos reservatórios, tempos de viagem da água em condições naturais e estimativas de evaporação e de usos consuntivos da água na bacia, como abastecimento humano e industrial e irrigação (ONS, 2014).

\subsection{MOTIVAÇÃO}

O Brasil depende bastante de recursos hidráulicos para geração de energia elétrica. Estes recursos hidráulicos precisam ser gerenciados de forma a haver integração com o uso de outros recursos não diretamente relacionados à geração de energia elétrica. $\mathrm{O}$ emprego de ferramentas computacionais que permitam a utilização otimizada de tais recursos é fundamental para o adequado aproveitamento dos recursos hídricos. De particular interesse, está o tratamento dado ao controle dos recursos hídricos com relação a cheias nas bacias hidrográficas.

Para citar um caso específico, chuvas em junho de 2014 na bacia do rio Iguaçu provocaram cheias, ocasionando recordes em diversos postos pluviométricos naquela bacia, com registros superiores a $200 \mathrm{~mm}$ por dia. Como consequência desta cheia e da operação hidráulica realizada para o seu controle, identificou-se a necessidade de implementação de medidas de aprimoramentos, sob as 
óticas metodológicas e de processos, em relação aos aspectos da operação hidráulica de controle de cheias nesta bacia hidrográfica. Classificada como uma das mais severas cheias da série histórica, identificou-se a não adequação da aplicação da classificação hidrológica até então empregada para o seu controle. Consolidou-se, então, a necessidade de uma operação hidráulica integrada não somente entre os reservatórios das usinas Foz do Areia e Segredo, mas também para todos os aproveitamentos hidroelétricos desta bacia. A operação integrada deveria compatibilizar a metodologia de rebaixamento dinâmico e integrado dos reservatórios de Foz do Areia e Segredo, a operação dos reservatórios à fio d'água de Salto Osório e Salto Caxias e avaliar uma nova metodologia de controle de cheias para o reservatório de Salto Santiago.

\subsection{OBJETIVO}

Esta dissertação tem como objetivo apresentar estudo da operação integrada dos reservatórios da cascata do rio Iguaçu e realizar simulações com base de dados utilizada em simulador para fins de avaliar a aplicação de rebaixamento dinâmico em reservatórios. Para viabilizar a operação hidráulica integrada dos aproveitamentos da bacia do rio Iguaçu, propõe-se a avaliação de critérios para a implantação de uma estratégia de testes. Estes critérios deverão conciliar as operações de alocação dinâmica de volume de espera, diagrama de operação normal, taxas de variação de defluência, as restrições associadas a cada reservatório bem como a operação hidráulica dos outros aproveitamentos hidroelétricos à jusante.

\subsection{ORGANIZAÇÃO DO TEXTO}

A dissertação está organizada em seis capítulos, conforme é descrito a seguir.

Além do capítulo introdutório, no Capítulo 2, realiza-se o levantamento de publicações apresentando metodologias e procedimentos de otimização aplicados à solução do problema de planejamento de curto, médio e longo prazo de sistemas hidrelétricos. Por sua vez, dedica-se o Capítulo 3 para apresentar fundamentos sobre rebaixamento.

No Capítulo 4, são apresentadas propostas de testes visando a realização de cálculos utilizando a técnica de rebaixamento do simulador hidráulico HydroExpert. Com este fim são propostas diversas simulações com realização de vários estudos de caso visando avaliar a regularização dinâmica da bacia hidrográfica do rio Iguaçu.

No Capítulo 5, descrevem-se os resultados da aplicação da técnica de rebaixamento dinâmico empregada para a bacia hidrográfica do rio Iguaçu. 
Por fim, no Capítulo 6, são apresentadas as conclusões e sugestões de trabalhos futuros que possam dar continuidade a esta pesquisa. 


\section{CAPÍTULO 2}

\section{REVISÃO BIBLIOGRÁFICA}

$\mathrm{Na}$ literatura, existem diversas publicações apresentando metodologias e técnicas de otimização aplicados à solução do problema de planejamento de curto, de médio e de longo prazo relacionado a sistemas hidrelétricos. Países como o Brasil, a Noruega, a Suécia e o Canadá são grandes produtores de hidroeletricidade, porém cada um adota uma metodologia de planejamento específica, de acordo com as características do seu sistema.

Na bibliografia sobre esse assunto, é grande a quantidade de modelos e metodologias propostas para a solução do problema de planejamento. Destacam-se as publicações de (Pereira ,1985) pela revisão e análise de estado da arte dessas metodologias e de (Pereira e Pinto, 1985) por descrever o modelo no qual se baseia a metodologia em vigor no setor elétrico. Rosenthal (1981), Dembo e Steihaug (1983), Beck et al. (1983), Carvalho e Soares (1987) e Oliveira e Soares (1985) desenvolveram técnicas de solução mais eficientes que não impõem limitações numéricas e computacionais ao se representar individualmente as usinas e o grande conjunto de restrições operacionais do sistema gerador.

Kelman et al. (1983) desenvolveram o modelo DIANA. É um modelo estocástico multivariado de geração de séries sintéticas de afluências diárias. O modelo foi desenvolvido de forma a reproduzir características marcantes e difíceis de serem modeladas das séries de afluências diárias, tais como, exageradas assimetrias, forte sazonalidade e a diversidade dos ramos de ascensão e recessão das hidrógrafas.

Soares e Salmazo (1987) demonstraram a importância do gerenciamento dos reservatórios das usinas de forma a otimizar a produção de energia elétrica, considerando restrições relativas ao volume dos reservatórios e a quantidade de água que pode ser defluída dos mesmos. Uma característica presente é o vertimento, indicando que, quando a capacidade da usina hidrelétrica é mais que suficiente para atender a demanda, pode ocorrer mais de um ponto de mínimo. O mínimo local, neste caso, é uma solução sem sentido físico porque exige que a produção exceda a demanda de energia.

Soares e Ohish (1989) desenvolveram uma metodologia para o problema de pré-despacho, a qual consiste na determinação de um programa de operação das unidades geradoras de um sistema de 
energia elétrica para um horizonte de curto prazo. A metodologia foi aplicada a um sistema hidrelétrico e utilizou iterativamente um modelo de despacho de máquinas, solucionado através de algoritmos genéticos, e um modelo de despacho de geração, resolvido com a técnica denominada relaxação lagrangeana. $\mathrm{O}$ despacho de máquinas permite a definição dos grupos geradores que estarão em operação em cada intervalo de tempo, tratando-se assim de um problema combinatório, o que justifica o uso de técnica como algoritmo genético. Em seguida, depois de definida a configuração de máquinas em operação, o despacho de geração é usado para solucionar um problema formulado somente com variáveis reais. A função aptidão (fitness function) do modelo de algoritmo genético leva em conta os custos iniciais e as perdas nas usinas hidrelétricas. A metodologia foi aplicada a um caso real do sistema de usinas hidrelétricas do rio Paranapanema. Para tornar a aplicação acessível ao usuário, foi desenvolvido um programa computacional, o qual integra a metodologia de pré-despacho com uma interface em ambiente do sistema operacional windows. Esta interface possibilita a definição da quantidade de usinas que devem operar, a configuração do algoritmo de despacho de máquinas, além da visualização de gráficos e tabelas.

CHESF (1989) desenvolveu o modelo SIMONE (Simulação Energética do Norte / Nordeste). É um simulador a usinas individualizadas, idealizado para atender às necessidades dos sistemas interligados específicos do Norte e Nordeste. O aplicativo permite a elaboração de estudos de planejamento e programação energética, para diferentes cenários de mercado e previsões de afluências, atendendo restrições operacionais definidas e premissas de operação. Este modelo não utiliza um algoritmo matemático de otimização, mas incorpora técnicas heurísticas de simulação, permitindo obter soluções próximas do ponto ótimo, considerando-se a experiência do simulador e as restrições atendidas.

Cicogna (1999) desenvolveu um modelo de planejamento da operação o HidroMax. A metodologia é baseada em algoritmos de fluxo em rede não linear. O sistema gerador representa de forma individualizada as usinas hidráulicas e termelétricas. Na formulação contida no modelo, considera-se detalhadamente a operação das usinas. No caso das hidrelétricas, a capacidade máxima da vazão turbinada é representada como uma função do armazenamento, o rendimento das turbinas e a variação do canal de fuga.

Cicogna (1999) também desenvolveu o modelo HydroPrev, um modelo de previsão de vazões baseado em redes neurais com lógica fuzzi. Neste modelo, a previsão de cada posto de vazões pode ser realizada em base mensal ou semanal. A metodologia de redes neurais combinada à lógica nebulosa possui desempenho superior ao modelos períodos auto-regressivos (PAR) de ordem $\rho$ (Ballini, 2000). 
Cicogna (1999) desenvolveu outro modelo de simulação de sistemas hidrotérmicos. Na metodologia são representadas de forma individualizada as usinas a serem simuladas, bem como uma grande coleção de restrições reais das condições operativas das usinas hidrelétricas e termelétricas.

Cicogna (1999) desenvolveu o modelo HydroSim de simulação de sistemas hidrelétricos. Neste modelo, são representados, de forma individualizada, os conjuntos de turbinas/geradores a serem simulados, bem como uma grande coleção de restrições relacionadas às condições operativas das usinas hidrelétricas em horizonte de curto prazo (por exemplo: tempo de viagem, operação de comportas e controle de cheias). O aplicativo sugere que a política a ser implementada deverá ser aquela que possui uma meta de geração e/ou defluência hidrelétrica pré-definida para cada usina. Essa política pode ser considerada uma regra aberta de simulação da operação de sistemas hidrelétricos, uma vez que o usuário tem a liberdade de determinar um programa de geração para as usinas, ou até um programa de vazões defluentes.

Costa et al. (1999) propuseram o sistema SPEC (Sistema para Estudos de Prevenção de Cheias) desenvolvido pelo CEPEL. Este modelo tem como objetivo apoiar estudos de prevenção de cheias. O modelo tem como foco principal a análise de sistemas multireservatórios/multipontos-decontrole-de-cheias situadas em bacias hidrográficas cujas hidrologias apresentam variações interanuais (sazonalidade). O modelo incorpora também facilidades para investigação e consideração da influência da situação de oscilação plurianual da circulação geral da atmosfera no Pacífico, conhecida como ENSO (El Niño-Oscilação Sul). Chaudhuri (2001) desenvolveu um modelo que agrupa em duas categorias principais: planejamento e programação. Estas duas categorias são suportadas por uma base de dados, denominada HydroData. Para a solução do problema de planejamento, dispõem-se de um modelo de otimização determinística alimentado por um modelo de previsão de vazões.

Cicogna (2003) cita que do ponto de vista da operação de curto prazo, é importante detalhar a operação das unidades geradoras. Para esta finalidade torna-se necessário definir a configuração dessas unidades geradoras ao longo da semana seguinte e seus respectivos pontos de operação, as restrições de operação do sistema hidrelétrico, restrições de uso múltiplo da água, restrições ambientais e restrições de operação do sistema termelétrico. A operação do sistema de transmissão também deve ser representada com detalhe, pois este procedimento constitui um dos aspectos mais críticos para a operação em tempo real do sistema. Em (Oliveira, Napomuceno e Soares, 2003), foi desenvolvido um modelo baseado em fluxo de potência ótimo. Neste modelo, uma função objetivo foi proposta tendo como alvo a minimização de custos de perdas na rede de transmissão e de desvios quadráticos em relação ao despacho de geração determinada onde a solução foi verificada hidraulicamente pelo simulador da operação hidrelétrica.

No capítulo seguinte são apresentados os fundamentos básicos para o desenvolvimento deste trabalho. 


\section{CAPÍTULO 3}

\section{FUNDAMENTOS SOBRE REBAIXAMENTO DE RESERVATÓRIOS}

\subsection{INTRODUÇÃO}

O rebaixamento em reservatórios ocorre quando o volume excedente que chega ao reservatório é superior ao volume vazio até o máximo volume operativo. Para se calcular o volume d'água excedente do reservatório, calcula-se o resultado da diferença entre a previsão de vazões afluentes e a programação de vazões turbinadas. Ou seja, esse volume excedente é então convertido em uma trajetória de vazão defluente considerando um espaço vazio no reservatório.

Neste capítulo, descrevem-se os fundamentos teóricos que norteiam o princípio de rebaixamento de reservatório de usinas hidrelétricas, com a apresentação somente do equacionamento básico e as caraterísticas da bacia do rio Iguaçu, a bacia estudada nesta dissertação.

Primeiramente, são apresentadas as funcionalidades para um horizonte de previsão, com ênfase no cálculo do volume vazio no reservatório, cálculo do volume em excesso comparando a afluência com a turbinagem. O principal objetivo é obter o cálculo do vertimento necessário para que o reservatório atinja o limite máximo no final do intervalo de previsão, respeitando a restrição de volume de espera a jusante.

\subsection{DEFINIÇÕES GERAIS}

Para melhor compreensão dos termos técnicos utilizados no tema tratado nesta dissertação, deve-se considerar a distinção entre os termos vazão natural e vazão afluente. No setor elétrico, tem sido adotado o termo vazão natural para identificar a vazão que ocorre em uma seção do rio, caso não houvesse as ações antrópicas na sua bacia contribuinte. Já o termo vazão afluente é utilizado para caracterizar a vazão que chega a um aproveitamento hidroelétrico ou estrutura hidráulica, que é influenciada por obras de regularização e demais ações antrópicas porventura existentes na bacia hidrográfica (ONS, 2014). 
A vazão natural em uma seção de um rio cuja bacia contribuinte está sujeita ao efeito das ações antrópicas é obtida por meio de um processo de reconstituição. Este processo considera as vazões afluentes e defluentes observadas nos reservatórios, tempos de viagem da água em condições naturais e estimativas de evaporação e de uso consuntivo da água na bacia, como abastecimento humano e industrial e irrigação (ONS, 2014).

A vazão afluente a um aproveitamento é, normalmente, calculada pelo balanço hídrico do seu reservatório, que corresponde ao balanço das entradas e saídas de água no seu interior, consideradas as variações efetivas de acumulação.

A vazão defluente é a vazão que sai de um reservatório, correspondente à soma da vazão turbinada, da vazão vertida e da vazão utilizada para outros fins. A vazão defluente turbinada é a vazão programada para ser liberada pelas turbinas de uma usina em um determinado período e a vazão defluente vertida é a vazão programada para ser liberada pelas estruturas extravasoras de uma usina (vertedouro) em um determinado período.

Já a regularização das vazões é o amortecimento das variações do escoamento de um curso d'água resultante de um armazenamento natural em um trecho de seu curso. É o efeito produzido pelos reservatórios no sentindo de reter o excesso d'água dos períodos de grandes vazões para ser utilizado nas épocas de seca. Qualquer que seja o tamanho do reservatório ou a finalidade das águas acumuladas, uma de suas principais funções é a de fornecer uma vazão constante (ou não muito variável), tendo recebido do rio vazões muito variáveis no tempo, ou seja, sua função é de regularização da vazão do curso d'água.

Um problema que se verifica nas bacias hidrográficas brasileiras é com relação ao controle de cheias. O controle de cheias por meio da alocação de volumes de espera é sujeito a risco, em função do caráter aleatório das cheias. Portanto, para determinar volumes de espera, estabelece-se o grau de proteção a ser adotado, em cada local de restrição denominado ponto de controle, expresso pelo tempo de recorrência.

O tempo de recorrência, $T_{R}$ é o intervalo de tempo médio necessário para que um determinado evento seja igualado ou excedido. Esse intervalo é estimado pelo inverso da sua probabilidade, $R I S C O$.

$$
T_{R}=\frac{1}{R I S C O} \quad \text { e } R I S C O=\frac{1}{T_{R}}
$$


O regime de cheias nas bacias hidrográficas nas quais os sistemas de reservatórios estão inseridos podem ser influenciados por fenômenos climáticos. Por esta razão, nos estudos são considerados cenários hidrológicos relacionados a esses fenômenos.

Durante o período de cheias, como resultado da vazão natural, é necessário realizar um rebaixamento de reservatórios existentes na bacia afetada para amenizar uma cheia, bem como sua recuperação na situação de estiagem. Conforme será estudado para a bacia do rio Iguaçu, destacam-se estudos realizados na usina do Foz do Areia. Em razão das condições hidro-meteorológicas indicando previsões elevadas de vazões afluentes à Foz do Areia, promove-se um rebaixamento hidráulico na usina com o objetivo de amortecer a cheia que deverá chegar. Com isto, procura-se evitar inundações em União da Vitória, cidade que fica à montante, conforme esquema ilustrativo da Figura 3.1.

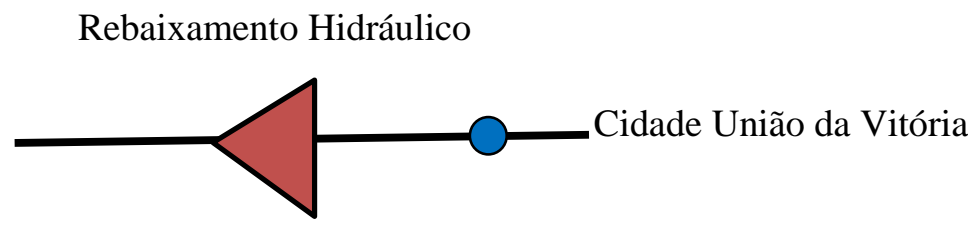

Usina Foz do Areia

Figura 3.1 - Representação esquemático para rebaixamento hidráulico.

\subsection{REBAIXAMENTO DINÂMICO DE RESERVATÓRIOS}

A técnica de rebaixamento dinâmico de reservatórios é baseada no cálculo de um volume de água excedente resultante da diferença entre a previsão de vazões afluentes e a programação de vazões turbinadas. $\mathrm{O}$ volume excedente é, então, convertido em um modelo que consiste em determinado quantificador denominado trajetória de vazão defluente.

Na Figura 3.2, é representado o volume excedente, que pode ser positivo (cinza homogêneo) ou negativo (representado pela região hachurada com linhas diagonais). 


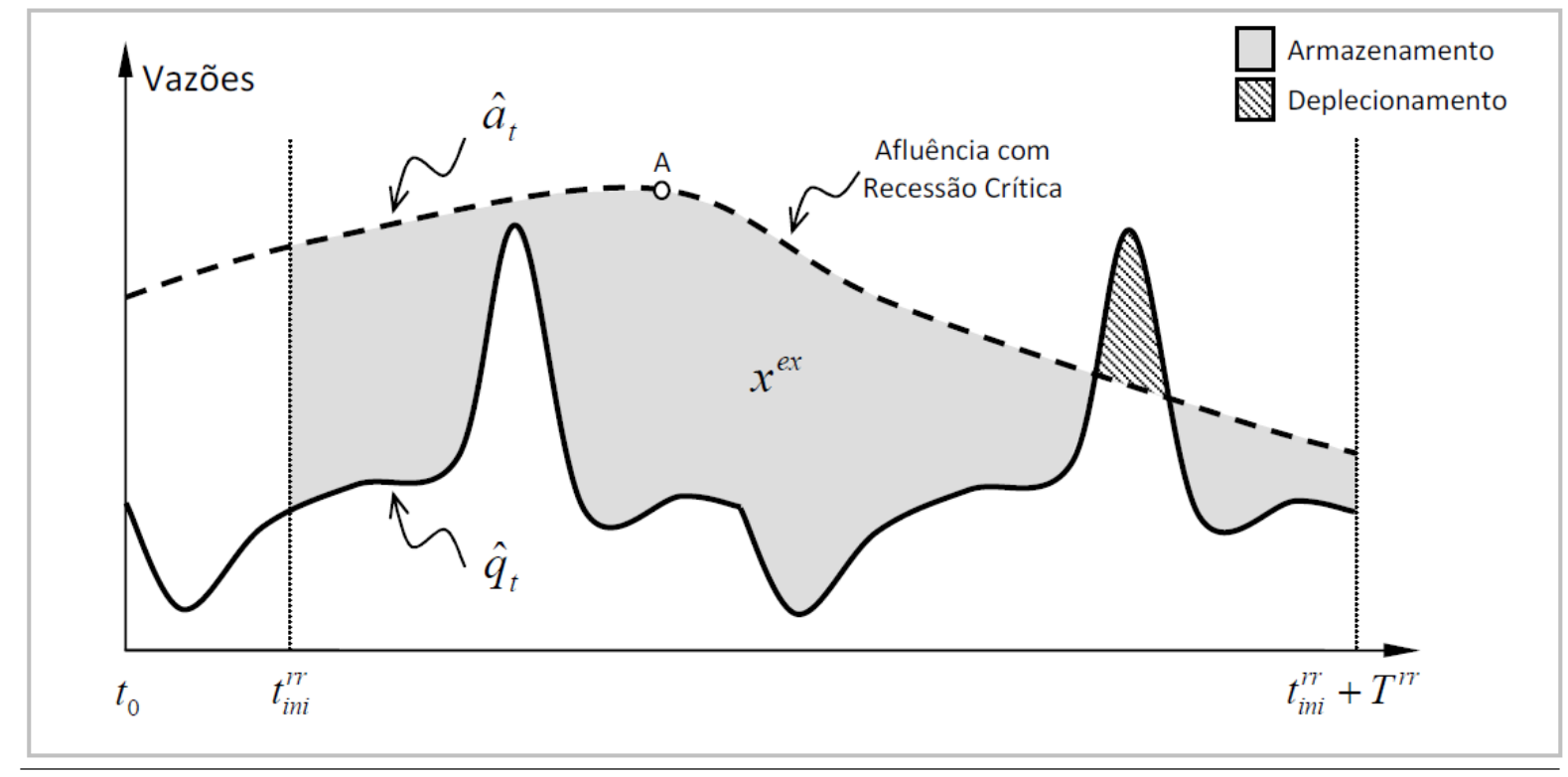

Figura 3.2 - Ilustração das trajetórias de vazões consideradas no cálculo do rebaixamento e recuperação dinâmicos do reservatório em um cenário ainda sem vertimento.

Na Figura 3.2, marca-se o ponto A como início da trajetória de vazões afluentes para um período de recessão crítica, normalmente, fornecida como trajetória de vazões incrementais. A recessão crítica tem relação direta com a característica de recuperação do reservatório, após rebaixamento do armazenamento por motivos de volume afluente em excesso (Cicogna, 2015).

O método demonstra a capacidade de rebaixamento e recuperação do reservatório, diferentemente do volume de espera estático para controle de cheias. Ou seja, a metodologia de rebaixamento dinâmico visa permitir aos reservatórios operar em sua plenitude. Entretanto, na iminência de uma cheia, aloca-se temporariamente um volume de espera e tão logo as vazões apresentem recessão consistentemente, de modo seguro, recupera-se o armazenamento de seu reservatório.

Ilustra-se a seguir a situação para o caso de dois reservatórios.

Seja um reservatório qualquer $i$ e um outro $j$, localizado à jusante. O problema consiste em se determinar a sua vazão defluente para um determinado cenário. Essencialmente, este problema é formulado considerando-se a diferença entre o aumento da vazão afluente, em comparação à previsão de vazões defluentes já programadas. O cenário descreve a situação de iminência de ocupação do volume vazio do reservatório, motivado pelo aumento de vazões afluentes.

Para que o reservatório à jusante identificado com o índice $j$ não seja imediatamente atingido pelas vazões à montante, são inseridas restrições de vazões. Assim, é evitada enchente, pois a vazão defluente em $i$ terá uma trajetória inferior à máxima vazão natural ao reservatório de índice $j$. 
O esquema na Figura 3.3 ilustra a situação em que os reservatórios $i$ e $j$ são considerados em que $y_{i, t}$ e $y_{j, t}$ são vazões incrementais associadas aos reservatórios $i$ e $j$, durante o intervalo t, em $\left[\mathrm{m}^{3} / \mathrm{s}\right]$

$u_{i, t}$ e $u_{j, t}$ são vazões defluentes associadas aos reservatórios $i$ e $j$, durante o intervalo t em $\left[\mathrm{m}^{3} / \mathrm{s}\right]$

$a_{i, t}$ e $a_{j, t}$ são vazões afluentes dos aproveitamentos $i$ e $j$, durante o intervalo t ( tempo de viagem). (Cicogna, 2009).

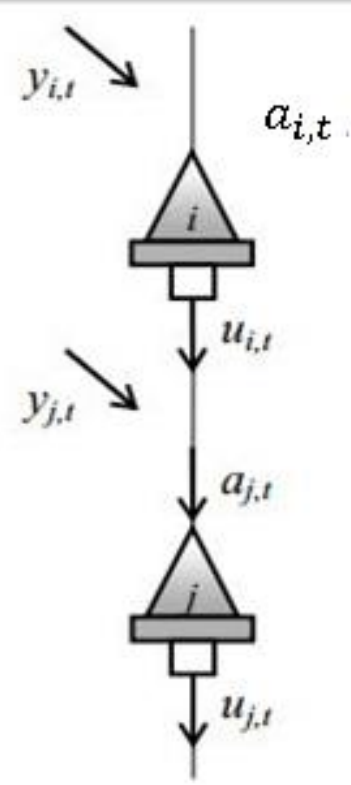

Figura 3.3 - Representação esquemática de dois reservatórios em um aproveitamento hidrelétrico.

\subsection{CÁLCULO DO VOLUME EXCEDENTE}

A partir do cálculo do volume excedente, deve-se determinar a vazão afluente ao reservatório composta pela soma das vazões defluentes dos reservatórios imediatamente à montante de interesse $i$, já considerando o tempo de viagem entre eles, e a previsão da vazão incremental. A equação (3.2) evidencia a estimativa de afluência para um determinado intervalado $t$.

$$
\hat{a}_{i, t}=\sum_{m \in \Omega_{i}} \hat{u}_{m, t-t v_{m}}+\hat{y}_{i, t}
$$


$\widehat{a}_{i, t}$ é a estimativa da vazão afluente do aproveitamento $i$, durante o intervalo $t$, considerando o tempo de viagem $[\mathrm{h}]$;

$\hat{y}_{i, t}$ é a estimativa da vazão incremental associada ao reservatório $i$, durante o intervalo $\mathrm{t}[\mathrm{h}]$;

$\Omega_{i}$ é um conjunto de índices dos aproveitamentos diretamente à montante de $i$;

$\hat{u}_{m, t}$ é a vazão defluente do aproveitamento de índice $m$, durante o intervalo $t[\mathrm{~h}]$;

$t v_{m}$ é o tempo médio de viagem da vazão defluente entre os reservatórios $m$ e $i,[\mathrm{~h}]$.

Considerando o cálculo através das vazões afluentes previstas e da programação de vazões turbinadas, o cálculo do volume excedente é realizado a partir das trajetórias de vazões afluentes previstas, conforme:

$$
x_{i}^{e x}=\sum_{t=t_{i n i}^{e x}}^{t_{i n i}^{e x}+T^{e x}}\left(\hat{a}_{i, t-} \hat{q}_{i, t+} \hat{d}_{i, t}\right) f_{c n}
$$

$\hat{q}_{i, t}$ é uma estimativa da vazão turbinada no reservatório $i$, durante o intervalo $t$;

$\hat{d}_{i, t}$ é uma estimativa da vazão de desvio, caso existam estruturas, associadas ao reservatório $i$, durante o intervalo $t$;

$t_{i n i}^{e x}$ é um índice do intervalo inicial de tempo do horizonte do estudo associado ao cenário de vazões para o qual se quer determinar o volume em excesso;

$T^{e x}$ é o número de intervalos de tempo do cenário de vazões para o qual se quer determinar o volume em excesso;

$f_{c n}$ é o fator utilizado para a conversão da unidade de vazão $\left[\mathrm{m}^{3} / \mathrm{s}\right]$ para a unidade de volume $\left[\mathrm{hm}^{3}\right]$.

\subsection{CÁLCULO DO VOLUME VAZIO}

O cálculo do volume vazio no reservatório está associado a uma cota. Este nível é determinado como a diferença entre o nível máximo operativo, e o volume inicial do reservatório no primeiro intervalo do horizonte de cálculo do rebaixamento, conforme definido a seguir:

$$
x_{i}^{v}=x_{i}^{\max }-x_{i, t_{i n i}^{e x}}
$$


O método de rebaixamento dinâmico determina de forma antecipada uma trajetória de vertimentos extras, caso ocorra um excedente de volume de água maior que o volume vazio no reservatório, considerando todas as restrições de cada aproveitamento (Cicogna, 2009).

\subsection{VAZÃO DEFLUENTE PARA REBAIXAMENTO E RECUPERAÇÃO}

$\mathrm{O}$ volume de água excedente pode assumir um valor positivo ou negativo. Na situação em que esse valor é positivo, determina-se o vertimento antecipado para rebaixamento e recuperação, $\hat{S}_{i, t}$, (Cicogna, 2015). Por outro lado, se o valor for negativo (necessidade de recuperação do reservatório), não é calculado um vertimento extra. Neste caso, a diferença que ocorre entre as trajetórias de afluência e vazões turbinadas fica armazenada no próprio reservatório.

$$
\hat{S}_{i, t}=\frac{x_{i}^{e x}-x_{i}^{v}}{T^{r r \Delta} t}, t=t_{i}^{r r}, \ldots t_{i}^{r r}+T^{r r}
$$

Em (Cicogna, 2015), $t_{i}^{r r}$ é definido como índice do intervalo inicial de tempo do horizonte do estudo relativo ao cenário de rebaixamento e recuperação dinâmicos;

$T^{r r}$, o número de intervalos de tempo para aplicação do rebaixamento e recuperação dinâmicos;

$\Delta_{t}$, a duração do intervalo de discretização do horizonte de estudo [s].

Os parâmetros $t_{i}^{r r}$ e $T^{r r}$ não são necessariamente iguais aos que servem para se determinar o intervalo de cálculo do volume de água em excesso. Em vista disso, é possível se obter um intervalo de rebaixamento e recuperação com duração inferior. Este procedimento dá lugar a um efeito de antecipação de vertimento frente à previsão de excesso no balanço de afluência e vazão turbinada, se comparado ao volume vazio do reservatório.

Considerando o volume excedente, na situação em que esse é superior ao volume vazio no reservatório, determina-se uma nova previsão para a programação de defluências do reservatório $i$, da seguinte forma:

$$
\hat{u}_{i, t}=\hat{q}_{i, t}+\hat{s}_{i, t}, \quad t=t_{i}^{r r}, \cdots, t_{i}^{r r}+T^{r r}
$$


Na situação em que o volume excedente é inferior ao volume vazio no reservatório, deve-se igualar a trajetória de vazão defluente à trajetória de vazão turbinada estimada por simulação. Ou seja,

$$
\hat{u}_{i, t}=\hat{q}_{i, t}, \quad t=t_{i}^{r r}, \cdots, t_{i}^{r r}+T^{r r}
$$

\subsection{VAZÃO DEFLUENTE PARA ATENDIMENTO DA MÁXIMA NATURAL}

A programação de vazões defluentes do reservatório $i$ deve atender a máxima vazão natural afluente no reservatório imediatamente à jusante. Um exemplo disso é o que ocorre na restrição operativa envolvendo os reservatórios das usinas hidrelétricas Foz do Areia e Segredo (Cicogna, 2015). Essa restrição tem origem no fato da vazão defluente do reservatório de jusante $j$ não poder ser superior à máxima vazão natural prevista para o mesmo, conforme equação a seguir.

$$
\widehat{u}_{i, t} \leq Y_{j}^{\max }
$$

A partir desta restrição, calcula-se a máxima vazão natural prevista no reservatório de jusante $j$, demonstrado em (3.8). Para este cálculo, é considerado o horizonte de rebaixamento $T^{r r}$ :

$$
y_{j}^{\max }=\max _{t_{i n i}^{r} \leq t \leq t_{i n i}^{t t}+T^{r r}}\left\{\hat{\gamma}_{i, t}+\hat{y}_{j, t}\right\}
$$

A parte da vazão natural prevista para o reservatório $j$ pode ser armazenada em seu volume vazio, caso exista, determinado pelo valor entre a cota do nível d'água atual e o nível máximo operativo, o qual pode ser calculado conforme equação abaixo (Cicogna, 2015):

$$
x_{j}^{v}=x_{j}^{\max }-x_{j, t_{i n i}^{e t}}
$$

Deve-se, então, limitar a estimativa de vazão defluente do reservatório de montante e de interesse, $\hat{u}_{i, t}$, em função da necessidade de rebaixamento, para que a restrição representada pela equação (3.8) seja atendida. Desta forma, para cada intervalo $t$, a vazão defluente em $i$, somada à vazão incremental do reservatório imediatamente à jusante $j$ e à vazão de desvio, quando presente, e, descontando -se a parcela armazenável no volume vazio no reservatório $j$, impõe-se este agrupamento de vazões que seja inferior à máxima vazão natural afluente prevista em $j$, conforme equação (3.11) (Cicogna, 2015).

$$
u_{i, t-t v_{i}}+\hat{y}_{j, t}+\hat{d}_{j, t}-\frac{x_{j}^{v}}{T^{r r} \Delta t} \leq \gamma_{j}^{\max }
$$


Sendo que $t v_{i}$ representa o atraso correspondente ao tempo de viagem da vazão entre os aproveitamentos $i$ e $j$. Colocando a referência temporal em termos da vazão defluente no reservatório de índice $i$, tem-se uma restrição de defluência para o intervalo $t$ representada pela equação (3.11).

$$
u_{i, t} \leq \gamma_{j}^{\max }-\hat{y}_{j, t+t v_{i}}-\hat{d}_{j, t+t v_{i}}+\frac{x_{j}^{v}}{T^{r r} \Delta t}
$$

\subsection{CARACTERIZAÇÃO DA BACIA DO RIO IGUAÇU}

A bacia do rio Iguaçu localiza-se na região Sul do país em grande parte no estado do Paraná. Esta bacia tem também áreas de contribuição no estado de Santa Catarina e na República Argentina. O rio Iguaçu, afluente do rio Paraná pela sua margem esquerda, drena uma área de $68.000 \mathrm{~km}^{2}$, em seu percurso de aproximadamente $1.100 \mathrm{~km}$. Suas nascentes se localizam na vertente leste da Serra do Mar (ONS, 2014).

A distribuição média de chuvas na bacia do rio Iguaçu não é uniforme, havendo uma tendência de aumento da precipitação na sua parte central, devido às barreiras naturais como a Serra da Boa Esperança. Outra característica importante deste trecho médio da bacia do rio Iguaçu (a partir da cidade de Porto Vitória), que se desenvolve sobre os derrames basálticos do $3^{\circ}$ Planalto Paranaense, é a fina espessura da camada de solo, que reduz a capacidade de infiltração, proporcionando maior escoamento superficial e, consequentemente, menor escoamento de base. Estas características da bacia se refletem nas enchentes, fazendo com que as vazões específicas máximas durante as cheias aumentem de montante para jusante, de forma contrária que a maioria dos rios.

Essa bacia possui características próprias que determinam distintos padrões de enchente ao longo da mesma. Apresenta também características geomorfológicas também distintas, tendo no planalto de Guarapuava, área de contribuição do rio Jordão, uma região de basalto com reduzida capacidade de retenção e regularização da água no seu subsolo. Aliado a este aspecto, a distribuição espacial das chuvas na bacia mostra maiores índices de pluviosidade na parte central, correspondente ao trecho denominado Médio Iguaçu. Baseado nessas considerações e na análise do histórico das vazões disponíveis, onde se observa um comportamento diferenciado das ondas de cheia ao longo da bacia, identificam-se três regiões hidrologicamente distintas e conhecidas por Alto, Médio e Baixo Iguaçu (ONS, 2015).

$\mathrm{Na}$ bacia do rio Iguaçu estão instaladas cinco usinas hidroelétricas de grande porte, dispostas em cascata, a saber: usina hidrelétrica (UHE) Foz do Areia (GBM) e UHE Segredo (GNB) da COPEL, UHE Salto Santiago e UHE Salto Osório, da TRACTEBEL ENERGIA e UHE Salto Caxias (GJR) da 
COPEL. No rio Jordão, afluente do rio Iguaçu pela margem direita, entre Segredo e Salto Santiago, estão instaladas as usinas UHE Santa Clara, UHE Fundão e reservatório de Desvio Jordão, todas operadas pela COPEL conforme ilustração na figuras 3.4.

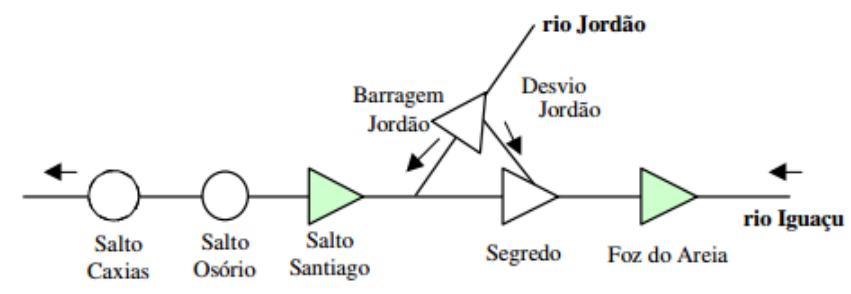

Figura 3.4 - Localização dos principais aproveitamentos hidroelétricos existentes na bacia do rio Iguaçu.

Na Tabela 3.1 apresentam-se as principais características dos aproveitamentos da bacia do rio Iguaçu.

Tabela 3.1 - Principais características dos aproveitamentos da bacia do rio Iguaçu

\begin{tabular}{|c|c|c|c|c|c|c|c|c|c|c|c|c|}
\hline \multirow[b]{2}{*}{ Nome } & \multirow[b]{2}{*}{$\begin{array}{l}\text { Tipo de } \\
\text { Sistema }\end{array}$} & \multicolumn{5}{|c|}{ Nivel (m) } & \multicolumn{2}{|c|}{$\begin{array}{c}\text { Área de Drenagem } \\
\qquad\left(\mathrm{km}^{2}\right)\end{array}$} & \multirow{2}{*}{$\begin{array}{l}\text { Distância } \\
\text { até a Foz } \\
(\mathrm{km})\end{array}$} & \multicolumn{3}{|c|}{$\begin{array}{c}\text { Distân cias e Tempos de } \\
\text { Viagem entre } \\
\text { Aproveitamentos }\end{array}$} \\
\hline & & $\begin{array}{c}\text { Mínimo } \\
\text { Operativo }\end{array}$ & $\begin{array}{l}\text { Máximo } \\
\text { Operativo }\end{array}$ & $\begin{array}{c}\text { Máximo } \\
\text { Maximorum }\end{array}$ & $\begin{array}{l}\text { Coroa: } \\
\text { mento }\end{array}$ & $\begin{array}{c}\text { Canal de } \\
\text { Fuga } \\
\text { (média) }\end{array}$ & $\begin{array}{c}\text { Total até o } \\
\text { Reserva- } \\
\text { tório }\end{array}$ & $\begin{array}{c}\text { Própria do } \\
\text { Reserva- } \\
\text { tório }\end{array}$ & & $\begin{array}{l}\text { Aproveita- } \\
\text { mentos }\end{array}$ & $(\mathrm{km})^{(1)}$ & $(h)^{(2)}$ \\
\hline $\begin{array}{l}\text { Gov. Bento Munhoz da } \\
\text { Rocha Netto }\end{array}$ & Interdependente & 700,00 & 742,00 & 745,00 & 748,00 & 602,00 & 30.127 & 29.900 & 550 & $\mathrm{GBM} / \mathrm{GNB}$ & 95 & 1 \\
\hline $\begin{array}{l}\text { Gov. Ney Aminthas de } \\
\text { Barros Braga }\end{array}$ & Interdependente & 602,00 & 607,00 & 608,00 & 610,00 & 490,00 & 34.346 & 4.219 & 450 & GNB / UHSS & 80 & 1 \\
\hline Santa Clara & - & 787,50 & 805,00 & 810,15 & 811,00 & 706,10 & 3.900 & 3.900 & $32^{(3)}$ & $\mathrm{SCL} / \mathrm{FND}$ & 20 & 2 \\
\hline Fundão & - & $705,00^{(4)}$ & 705,50 & 711,00 & 712,50 & 610,05 & 4.090 & 190 & $23^{(3)}$ & FND / DRJ & 12 & 1,8 \\
\hline Desvio Jordão & - & 602,00 & 610,00 & 614,80 & 615,00 & 538,35 & 4.730 & 640 & $3^{(\beta)}$ & DRJ / UHSS & 80 & 1 \\
\hline Sal to Santiago & Interdependente & 481,00 & 506,00 & 509,00 & 510,00 & 397,00 & 43.852 & 4.776 & 357 & UHSS / UHSO & 70 & 1 \\
\hline Salto Osório & - & 389,00 & 397,00 & 398,00 & 401,00 & 324,00 & 45.769 & 1.917 & 307 & UHSO / GJR & 95 & 1 \\
\hline Gov. José Richa & - & 323,00 & 325,00 & 326,00 & 328,00 & 259,00 & 56.977 & 11.208 & 210 & - & - & - \\
\hline
\end{tabular}

(1) Valor estimado.

(2) Tempo médio em condições de reservatório.

(3) Até a confluência com o rio Iguaçu.

(4)Na UHE Fundão, o nível da soleira vertente é 705,50 m (vertedor de superfície) e o nível operacional mínimo de projeto é 703,50 m, mas devido à impossibilidade prática de se operar esse Reservatório em níveis inferiores a 0,50 m abaixo do nível máximo normal (crista do vertedor), adotou-se o nível de 705,00 m como o novo nível mínimo operativo do reservatório que atende aos requisitos de cobrimento mínimo na tomada d'água, para evitar entrada de ar e formação de vórtices. 


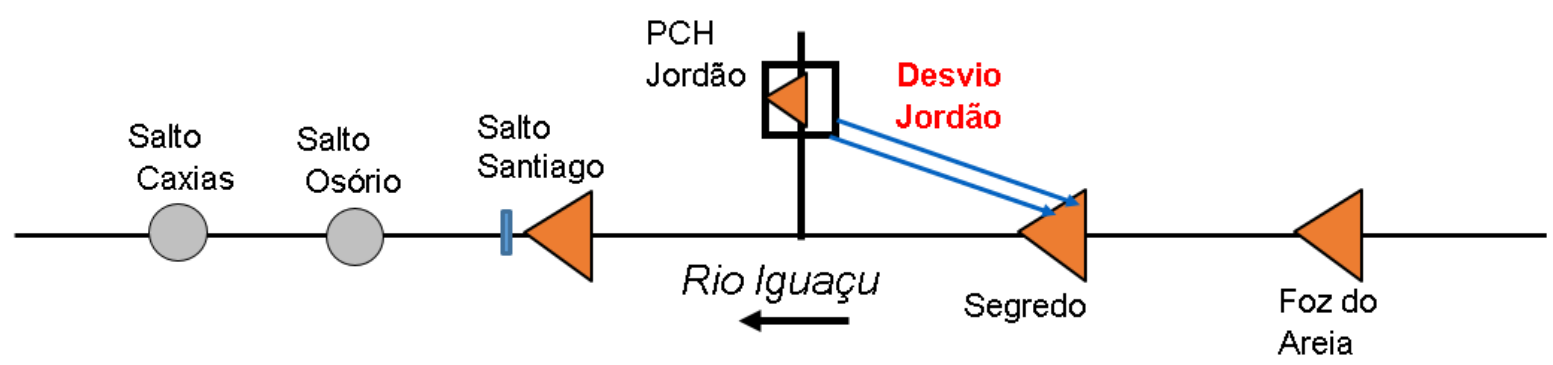

Figura 3.5 - Diagrama do sistema de aproveitamentos hidrelétricos da bacia do rio Iguaçu.

A figura 3.5 apresenta o diagrama unifilar da bacia do rio Iguaçu com as suas respectivas potências nominais.

\subsection{RESTRIÇÕES HIDRÁULICAS EXISTENTES NA BACIA DO RIO IGUAÇU}

As restrições de vazão máxima devem ser atendidas por um ou mais reservatórios situados a montante atendendo as características de cada bacia conforme tabela 3.1.

A figura 3.6 apresenta um exemplo de uma operação hidráulica onde devem ser respeitadas as restrições operativas de cada aproveitamento. A proteção desejada aos locais sujeitos a inundação implica no estabelecimento de restrições como:

Q-RESTR - restrição de vazão máxima

Q-DEFL - restrição de máxima defluência

Q-AFL - restrição de máxima afluência

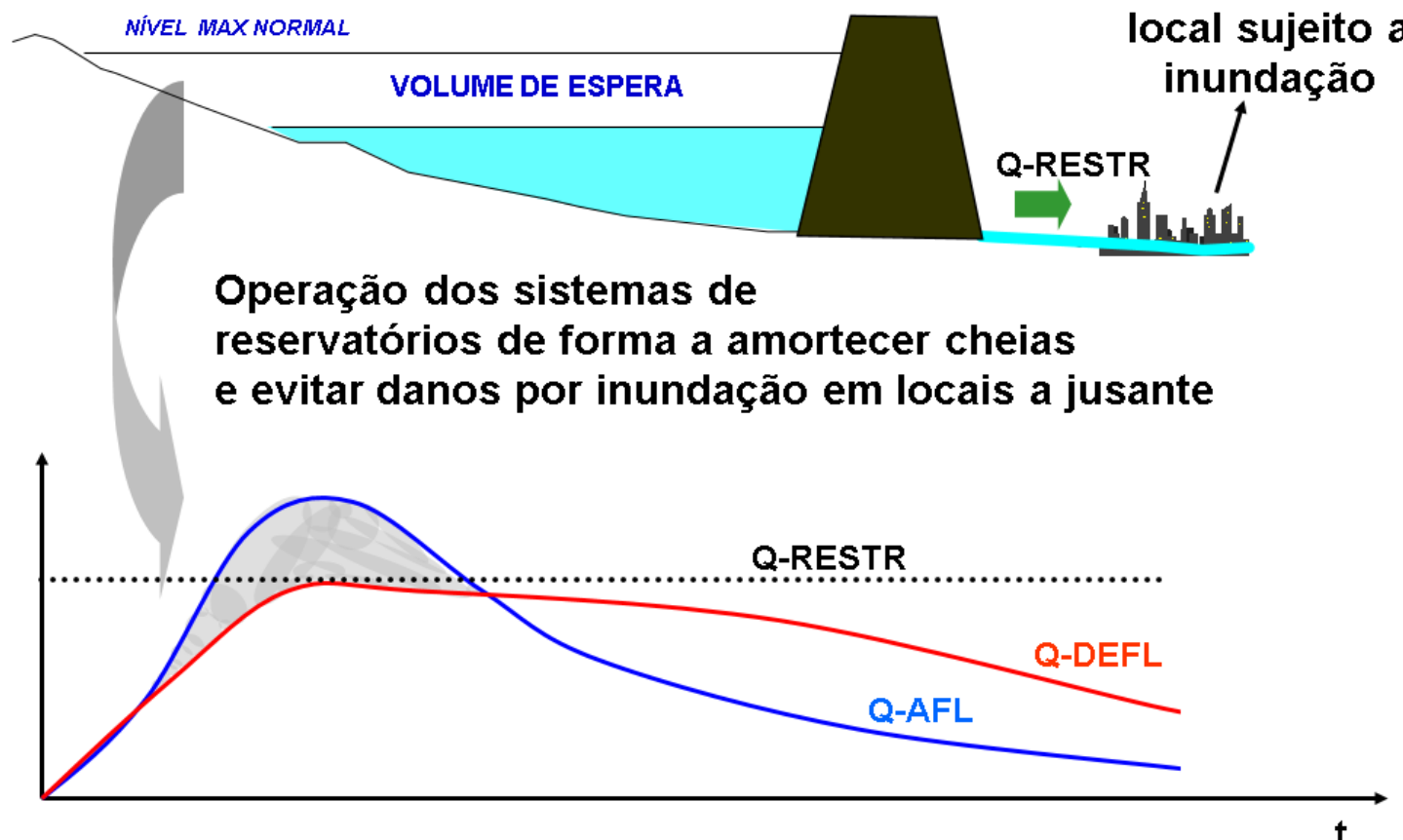

Figura 3.6 - Restrições operativas de um aproveitamento. 
Descrevem-se a seguir as restrições relacionadas aos principais aproveitamentos pertencentes à cascata da bacia do rio Iguaçu.

\subsubsection{UHE Foz do Areia}

O aproveitamento de Foz do Areia, o primeiro da cascata, possui uma restrição de operação caracterizada pela influência do seu reservatório, em certas condições de cheias, nos níveis de inundação das cidades de União da Vitória (PR) e Porto União (SC), localizada na cabeceira. Essa influência é determinada pelas curvas de remanso calculadas pela COPEL (CEHPAR, 2002), que permitem estabelecer, em tempo real a ser considerado com restrição, com base nos níveis de água observados, simultaneamente, em Foz do Areia e União da Vitória. Assim, a restrição de nível do reservatório de Foz do Areia não é um valor constante, e sim variável e determinado em tempo real, através das curvas de remanso deste reservatório (ONS, 2015).

A operação de controle de cheias do reservatório de Foz do Areia visa evitar o agravamento das enchentes em União da Vitória e Porto União, em áreas situadas acima da cota de desapropriação. Essa operação é denominada rebaixamento dinâmico e baseia-se no recurso de previsão da vazão afluente, na preservação do fim energético (pela recuperação do nível máximo normal 742,00 m no final da cheia) e na disponibilidade de volumes vazios nos reservatórios de jusante. A operação em Foz do Areia é executada de forma integrada com a UHE Segredo, de modo a não provocar aumentos na vazão máxima à jusante do sistema de reservatórios sob a coordenação do ONS que deverá levar em consideração as afluências verificadas nas bacias existentes nos reservatórios de jusante.

\subsubsection{UHE Segredo}

A Usina Hidrelétrica Governador Ney Aminthas de Barros Braga (UHE Segredo) usa de um artifício inovador para aumentar a sua capacidade de produção de energia. Como o local onde ela está instalada fica a apenas $2 \mathrm{~km}$ do local onde o Rio Jordão deságua no Rio Iguaçu, a Copel criou uma segunda barragem no Rio Jordão e construiu um túnel de $4703 \mathrm{~m}$ de comprimento e 9,5 m de diâmetro para interligar as duas barragens. Esta obra acrescentou cerca de $10 \%$ a mais de capacidade de produção de energia para a usina. (COPEL,2016)

A barragem principal da Usina Ney Braga tem um comprimento de $700 \mathrm{~m}$ e impressionantes $145 \mathrm{~m}$ de altura. O nível do reservatório fica a aproximadamente $640 \mathrm{~m}$ de altitude. (COPEL,2016)

A vazão defluente utiliza as seguintes taxas de referências de variação máxima de defluência. 
QD $\leq 2.000 \mathrm{~m}^{3} / \mathrm{s} \rightarrow$ Taxa Máxima de Variação da Defluência $=600 \mathrm{~m}^{3} / \mathrm{s} / \mathrm{h}$

QD $>2.000 \mathrm{~m}^{3} / \mathrm{s} \rightarrow$ Taxa Máxima de Variação da Defluência $=1.000 \mathrm{~m}^{3} / \mathrm{s} / \mathrm{h}$

onde QD é a Vazão Defluente.

\subsubsection{UHE Salto Santiago}

O reservatório da usina Salto Santiago, pertencente à Tractebel Energia realiza operação de controle de cheias para evitar a inundação da sua própria casa de força, na ocorrência de vazões defluentes superiores a $19.000 \mathrm{~m} 3 / \mathrm{s}$. Durante a cheia de julho de 1983 , verificou-se que, para vazões defluentes da ordem de $16.000 \mathrm{~m}^{3} / \mathrm{s}$, correspondente à cota $416,00 \mathrm{~m}$ no canal de fuga, a casa de força poderia ser inundada. Após esse evento, foi construído um muro de proteção entre a casa de força e o canal de fuga, com coroamento na cota 419,00 metros, elevando o valor da restrição para $19.000 \mathrm{~m}^{3} / \mathrm{s}$, que atualmente corresponde a um Tempo de Recorrência (TR) de 150 anos (ONS, 2016)

À jusante da usina Governador José Richa (Salto Caxias), existe uma ponte rodoviária da PR182 sobre o rio Iguaçu, entre os municípios de Capitão Leônidas Marques e Marmelândia, para o qual a COPEL informou como restrição a vazão de $30.000 \mathrm{~m}^{3} / \mathrm{s}$. A COPEL adota medidas para manter informadas as comunidades usuárias da referida ponte rodoviária, em situações em que houver perspectivas da vazão atingir valores da ordem de $30.000 \mathrm{~m} 3 / \mathrm{s}$ naquele local. Esta vazão corresponde a um tempo de recorrência superior a 100 anos, usual no dimensionamento deste tipo de obra (ONS, 2015).

\subsubsection{UHE Salto Osório}

A vazão defluente mínima é de $200 \mathrm{~m}^{3} / \mathrm{s}$, para preservação da ictiofauna. Sendo assim, sempre que não houver vazão turbinada (unidades geradoras operando na modalidade de compensador síncrono ou desligadas), deve-se realizar vertimento, utilizando-se, obrigatoriamente, o Vertedouro $\mathrm{n}^{\circ}$ 1, de maneira a manter vazão pelo canal de fuga.

Essa restrição se deve às condições físicas específicas na região do canal de fuga da usina, ocorrendo surgimento de cardumes no leito desse canal, junto à casa força, podendo as espécies de peixes serem afetadas pela falta de oxigenação e variação de temperatura da água (ONS, 2016).

\subsubsection{UHE Salto Caxias}

Segundo levantamentos realizados pela COPEL, à jusante de Salto Caxias até o final do trecho exclusivamente nacional do Iguaçu, há propriedades agrícolas, instalações agropecuárias e sedes de 
fazendas que são gradativamente atingidas por vazões muito altas, como as ocorridas em 1983 e 1992 . Neste trecho, é importante observar que a usina Salto Caxias mantenha taxas de variação de defluência compatíveis com as taxas das cheias naturais, o que possibilitará uma evacuação ordenada das áreas de várzea durante os eventos de cheias (ONS,2015).

A cada ano é sinalizado qual período hidrológico deverá ser caracterizado para cada região. No ano de 2014, foi previsto que o cenário seria de período normal. Com isso, não houve preocupação com relação à bacia do Iguaçu em realizar uma operação especial, caso ocorresse uma grande vazão com muita chuva ou com estiagem.

Porém, em meados do ano de 2014, a bacia do Iguaçu foi surpreendida com uma grande quantidade de chuva, que pelo histórico foi considerada a maior cheia. Após essa ocorrência, a bacia ficou exposta a qualquer cenário possível.

Diante disso, essa dissertação objetiva viabilizar rebaixamento dinâmico nos reservatórios dessa bacia, de forma coordenada, para que seja possível alocar um volume de espera, considerando todas as restrições dos aproveitamentos diante de diversas ocorrências de cheias.

\subsection{Volume excedente e NA máximo maximorum}

A Figura 3.7 apresenta alguns termos utilizados. O NA (nível de armazenamento) máximo maximorum de um reservatório corresponde à sobrelevação máxima do nível d'água, medida a partir do NA máximo operacional, disponível para passagem de ondas de cheias. Em aproveitamentos hidrelétricos de grande porte para o cálculo do NA máximo maximorum está associada a cheia de projeto com tempo de retorno de 10.000 anos (decamilenar).

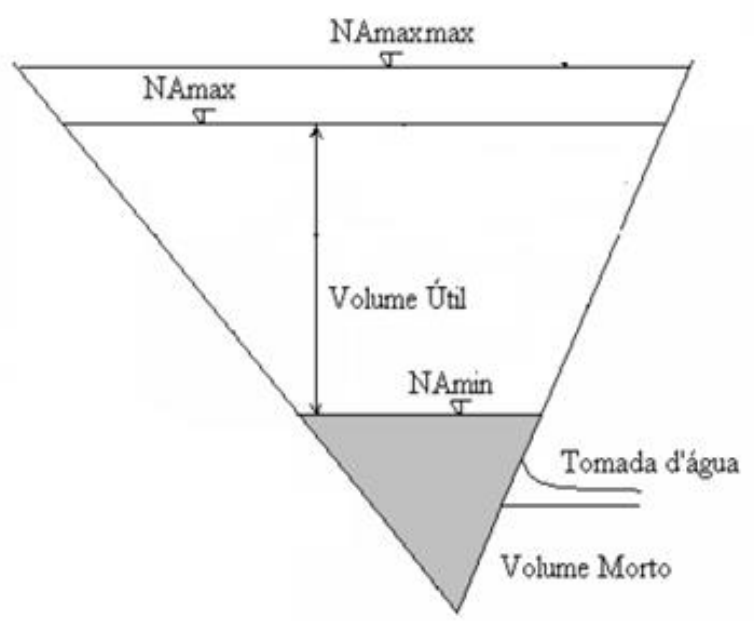

Figura 3.7 - Esquema NA máximo maximorum. 


\subsection{Volume útil e NA máximo operacional}

A Figura 3.8 apresenta o NA máximo operacional, onde corresponde à cota máxima para a operação do reservatório em condições normais. Em geral coincide com a borda superior das comportas do vertedor ou a crista dos vertedouros de lâmina livre. Corresponde também ao volume entre os níveis mínimos operacionais e máximo operacional. Este é o volume de armazenamento necessário em um reservatório para garantir uma vazão regularizada constante, durante o período mais crítico de estiagem.

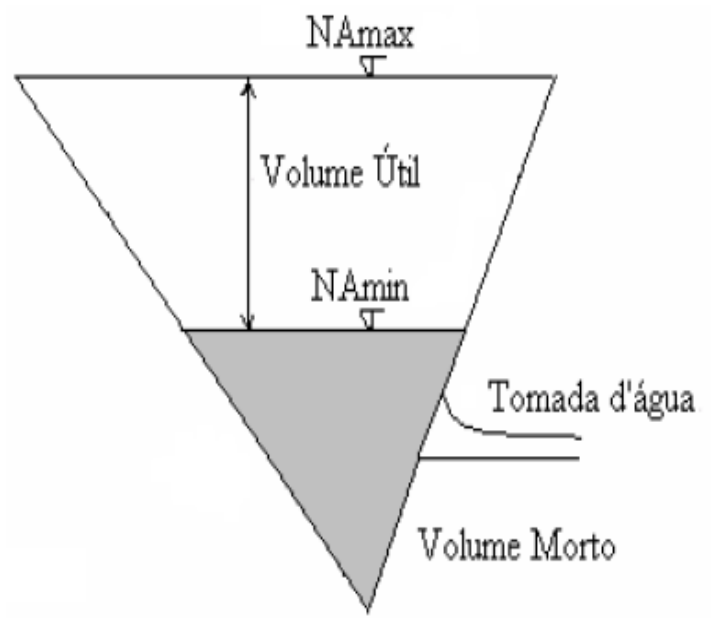

Figura 3.8 - Esquema NA máximo operacional.

\subsection{Volume morto e NA mínimo operacional}

A Figura 3.9 apresenta o volume morto onde corresponde à parcela de volume total do reservatório inativa ou indisponível para fins de captação da água. O NA mínimo operacional corresponde à cota mínima necessária para operação adequada do reservatório. Normalmente, o NA mínimo operacional encontra-se acima do limite superior da estrutura de tomada d'água de forma a evitar a formação de vórtices. 


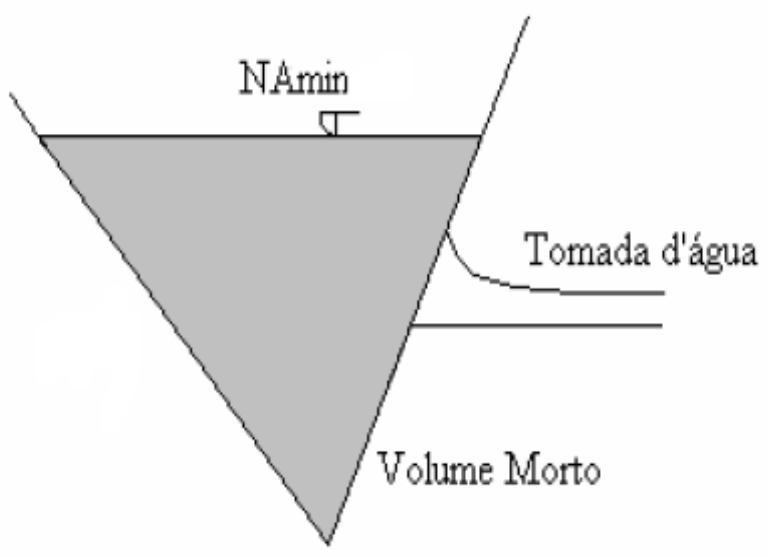

Figura 3.9 - Esquema NA mínimo operacional.

Ao se adotar o uso do simulador hidráulico HydroExpert que permite uma antecipação de decisões que proporciona um maior conforto para o Setor Elétrico como será apresentado no capítulo 4, deve ser considerando as características especificas dos aproveitamentos hidroelétricos citados neste capítulo, assim como os fundamentos da rotina do rebaixamento dinâmico que permite antecipar vertimentos frente a vários cenários hidrológicos ou necessidades do SIN. 


\section{CAPÍTULO 4}

\section{SIMULADOR HIDRÁULICO HYDROEXPERT}

\subsection{INTRODUÇÃO}

Com o propósito de avaliar o método de rebaixamento com a utilização do simulador hidráulico HydroExpert serão efetuadas simulações com realização de vários estudos de caso que têm como objetivo avaliar a regularização dinâmica da bacia hidrográfica do Rio Iguaçu. As antecipações de rebaixamento dos reservatórios dessas usinas são recomendadas quando os resultados dos estudos indicam a iminência de ocupação do volume vazio dos mesmos. Os cálculos e os resultados obtidos são dados em base horária e para determinados períodos pré-estabelecidos.

\subsection{O APROVEITAMENTO HIDROELÉTRICO SIMULADO.}

As análises abordaram o problema relativo ao rebaixamento e recuperação de reservatórios de aproveitamentos hidrelétricos. A importância deste tema está no fato do Brasil ser um país cuja matriz de energia elétrica ser, em grande parte, de natureza hidroelétrica. Desta forma, os reservatórios, dependendo das condições climáticas, ficam sujeitos a pequenos e grandes volumes de água. Na condição de cheia, há a necessidade de coordenação do controle de vazões. Em função disso, destaca-se a importância da previsibilidade das vazões.

Neste trabalho, utiliza-se o simulador HYDROEXPERT versão 1.6.7 RC. Trata-se de simulador hidráulico, conectado a uma base de dados técnicos de aproveitamentos hidroelétricos. $\mathrm{O}$ software é composto por aplicativos, um banco de dados próprio e permite conexões com banco de dados de diversas empresas, no qual faz-se uso de um banco de dados denominado HydroData, que por sua vez recebe os dados temporais dos aproveitamentos da BDT - Base de Dados Técnica do ONS. São permitidas simulações para todas as usinas em operação no Sistema Interligado Nacional (SIN) com discretizações: mensal, semanal, diária, horária e de meia-hora. A partir do acesso às bases de dados estáticos e dinâmicos, ao se criarem estudos na interface gráfica, os dados são armazenados em arquivos textos locais e legíveis por parte do usuário. Esse aspecto, uma vez compartilhados os arquivos de um estudo qualquer, garante a reprodutibilidade dos resultados, independente do ambiente computacional em uso. Além disso, um recurso secundário, mas importante, é a portabilidade do software e seus estudos, pois o HydroExpert pode ser utilizado a partir de dispositivos móveis de armazenamento como, por exemplo, cartões de memorias ou pendrives. (Guilhon, Cicogna,2013). 
O simulador hidráulico HydroExpert vem sendo utilizado de forma crescente por empresas do setor elétrico e mais especificamente pelo ONS, com as mais diferentes funcionalidades. Por se tratar de um aplicativo que acessa uma base de dados característicos de aproveitamentos hidroelétricos, o HydroExpert permite que, a partir da simulação de dados operativos efetivamente praticados, possa se obter uma verificação dos dados característicos existentes (Guilhon, 2010). Considerando a integração com uma base de dados de usinas hidroelétricas, aliado à sua grande facilidade de uso e sua portabilidade, o HydroExpert constitui-se também numa plataforma para a integração de aplicativos já existentes que não possuem uma interface amigável. (Guilhon, Cicogna, 2013).

$\mathrm{Na}$ seção que se segue, utiliza-se a metodologia descrita acima e faz-se uso do HydroExpert para aplicações em usinas da bacia do rio Iguaçu com o objetivo de antecipar um rebaixamento de um reservatório. Com isto, se obtém um volume vazio no reservatório rebaixado, e assim, armazenar um grande volume de água nesse reservatório sem causar danos a outros aproveitamentos.

A metodologia foi aplicada a aproveitamentos da bacia do Rio Iguaçu, destacando-se estudos relativos aos reservatórios das UHE Foz do Areia, Segredo e Salto Santiago.

\subsection{SOLUÇÃO INICIAL PARA A PROGRAMAÇÃO DE DEFLUENCIAS.}

Neste método, descrito em (Cicogna, 2015), deve-se criar um estudo no simulador HydroSim XP que contenha os reservatórios de interesse, indicando uma data de referência e fornecendo os dados de entrada principais:

A cota inicial dos reservatórios na data e hora de referência do estudo [m].

A programação de geração em base horária ou diária para cada UHE [MW].

A programação de vertimentos, caso exista, para cada UHE $\left[\mathrm{m}^{3} / \mathrm{s}\right]$.

A previsão de vazões incrementais em base horária ou diária $\left[\mathrm{m}^{3} / \mathrm{s}\right]$.

Segundo Cicogna (2015), a execução de tal estudo no simulador permite determinar uma programação de vazões defluentes em concordância com a programação de geração. Além disso, essa solução inicial deverá ser criada respeitando-se a lista de restrições conforme (HydroLab, 2005 b e c), como segue:

As vazões defluentes mínimas e máximas (restrição de jusante).

A vazão turbinada máxima.

As cotas mínimas e máximas operativas dos reservatórios.

A cota limite (volume de espera) para o controle de cheias.

As vazões de desvio entre os aproveitamentos. 
O tempo de viagem entre reservatórios.

Em Cicogna (2015), devido ao atendimento automático das restrições citadas, o simulador HydroExpert fornece como resultado uma previsão factível da operação hidráulica futura dos reservatórios. Essa solução inicial fornece, em forma de trajetória, o comportamento das vazões turbinadas, vertidas e defluentes, e com correspondente impacto na trajetória de armazenamentos dos reservatórios. A análise das trajetórias de vazões defluentes e armazenamentos dos reservatórios do estudo, existentes na solução inicial obtida no primeiro passo do algoritmo, permite ao usuário do HydroExpert decidir a necessidade ou não de entrar no módulo de cálculo do rebaixamento e recuperação dinâmicos de algum reservatório com existência de vertimentos não programados.

Para avaliar a rotina de rebaixamento dinâmico, o próximo capítulo apresenta os resultados que permite antecipar decisões de vertimento frente a um cenário de cheias, promovendo uma redução no nível do reservatório e alocando volumes vazios para atenuar a possível enchente futura. 


\section{CAPÍTULO 5}

\section{APRESENTAÇÃO E ANÁLISE DE RESULTADOS}

Nesta seção, descrevem-se os resultados da aplicação da técnica de rebaixamento dinâmico na bacia hidrográfica do rio Iguaçu. O objetivo é determinar de forma escalonada trajetórias de vertimento extras nos reservatórios dessa bacia, caso ocorra um excesso de volume de água, não dependendo exclusivamente da previsão do cenário hidrológico.

O módulo rebaixamento dinâmico atua sobre um estudo que já possua resultados. Desta forma, define-se, dentro do horizonte de estudo, o período considerado para as previsões de vazão afluente e comportamento do reservatório selecionado.

\subsection{A BACIA SIMULADA}

Inicialmente, é apresentado o diagrama esquemático da bacia do rio Iguaçu, com todas as usinas representadas de forma especifica para cada aproveitamento (Figura 5.1). Nas simulações, são analisados dados de semanas operativas distintas, considerando diferentes cenários hidrológicos.

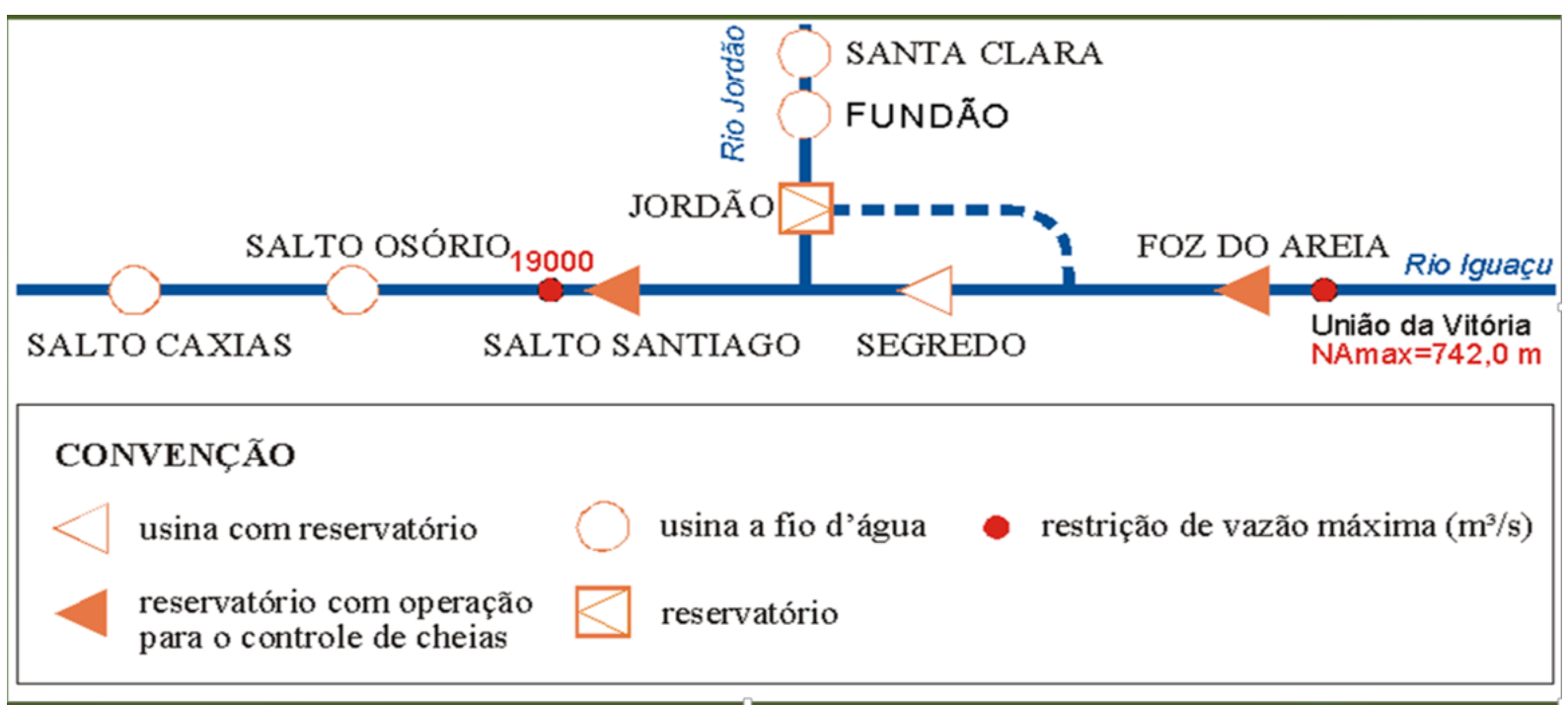

Figura 5.1 - Diagrama esquemático da bacia do rio Iguaçu. 


\subsection{ANÁLISE DA SEMANA OPERATIVA DE 01/02 A 05/02/2015 COM VOLUME EXCEDENTE MAIOR QUE O VOLUME VAZIO.}

Conforme a Figura 5.2, o volume excedente previsto ficou maior que o volume vazio no reservatório da UHE Foz do Areia, sendo a vazão (média) vertida com 552, 8m³/s, o qual será alvo do cálculo de rebaixamento dinâmico, onde é sinalizada através de cores.

A restrição do reservatório deverá ser ativa fazendo com que a vazão vertida de montante respeite a vazão natural máxima calculada para o aproveitamento de jusante durante o período selecionado de previsão.

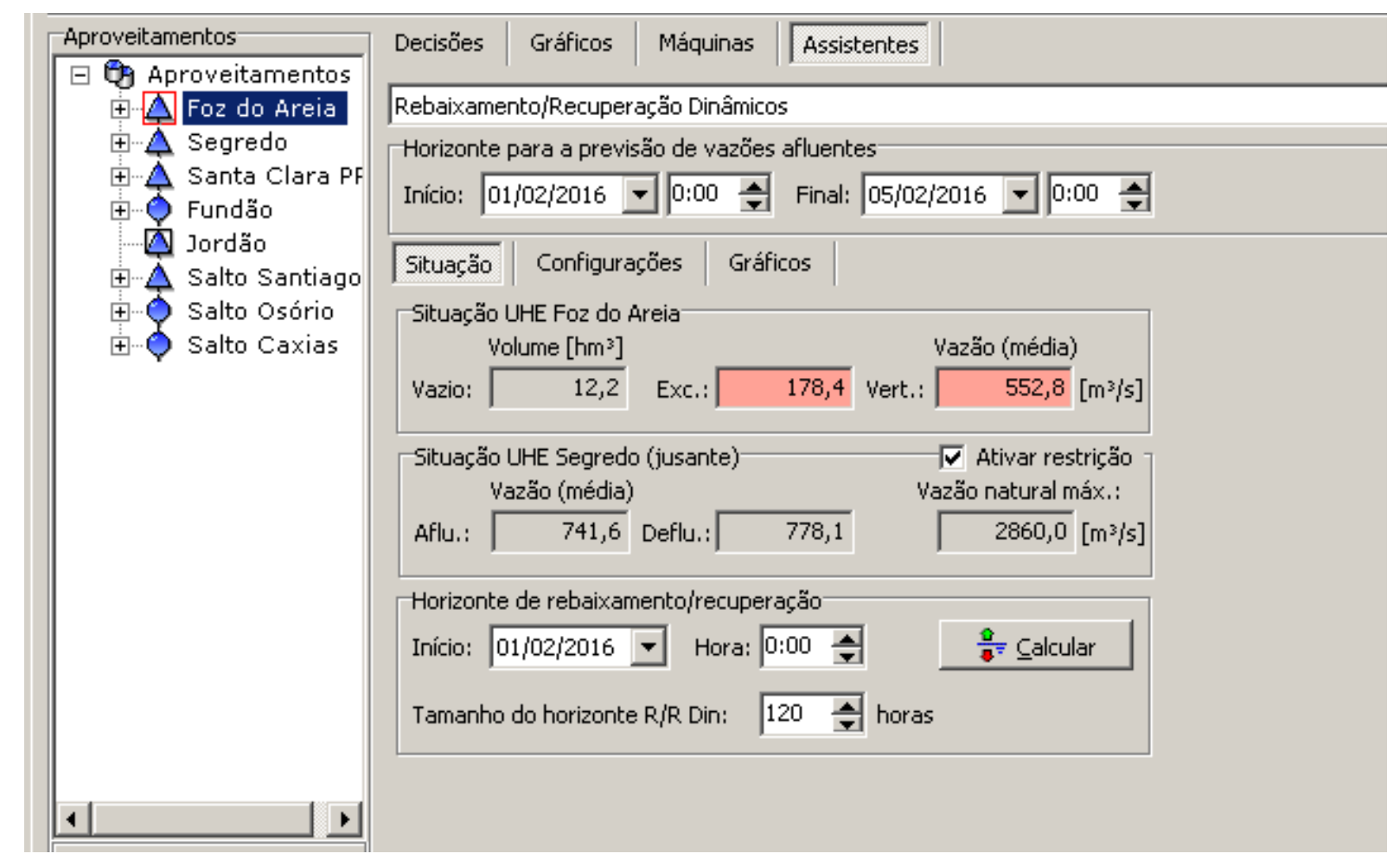

Figura 5.2 - Indicação do volume excedente previsto no horizonte de previsão de afluências.

Foi simulado um rebaixamento de 48 horas na UHE Foz do Areia, a partir do primeiro dia do horizonte de previsão, onde será confirmada a alteração da programação de vazões vertidas para o rebaixamento. Ou seja, é feito o cálculo do vertimento necessário para que o reservatório atinja o limite máximo no final do intervalo de previsão, respeitando a restrição de volume de espera de jusante conforme figura 5.3. 


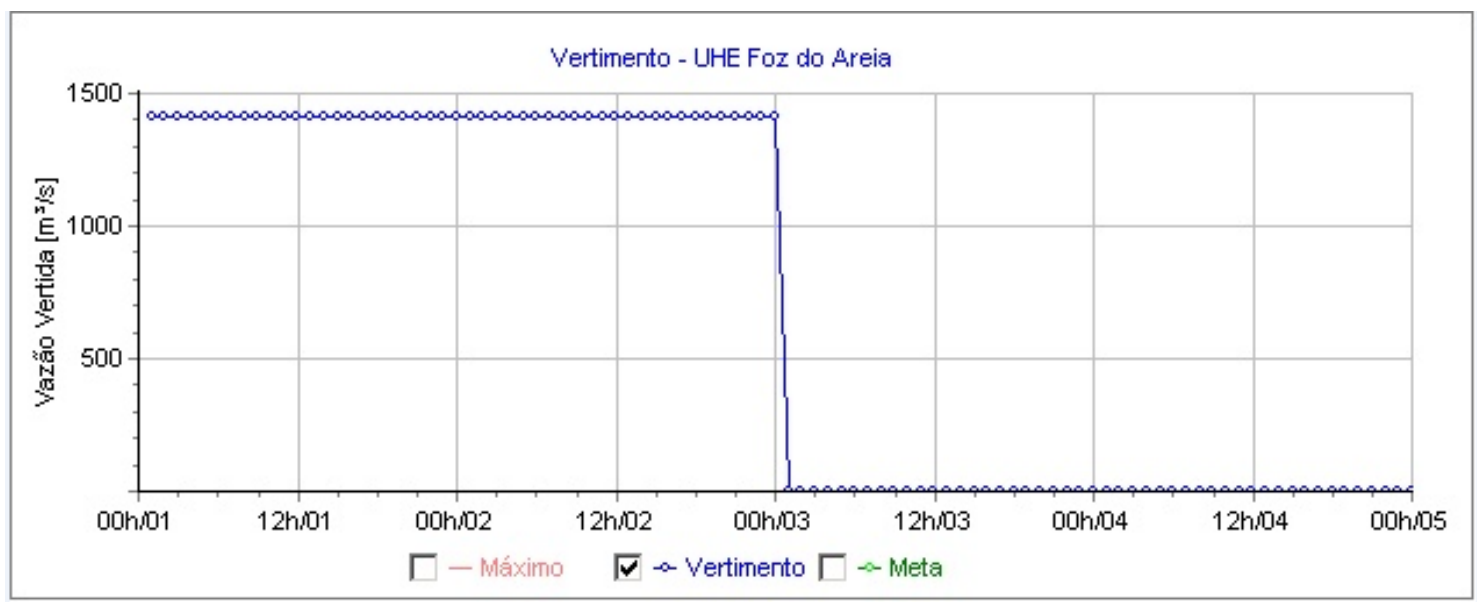

Figura 5.3 - Indicações da vazão na abertura do vertedouro da UHE Foz do Areia

Como consequência do vertimento programado escalonado na UHE Foz do Areia, as Figuras 5.4 a 5.7 indicam os resultados da bacia com o vertimento necessário até que atinja o limite máximo no final do intervalo previsto.

UHE Segredo:

A figura 5.4 indica como consequência do vertimento programado de até $1400 \mathrm{~m} / \mathrm{s}$ e o fechamento do vertedouro $01 \mathrm{~h} 00 \mathrm{~h}$ do dia $03 / 02$.

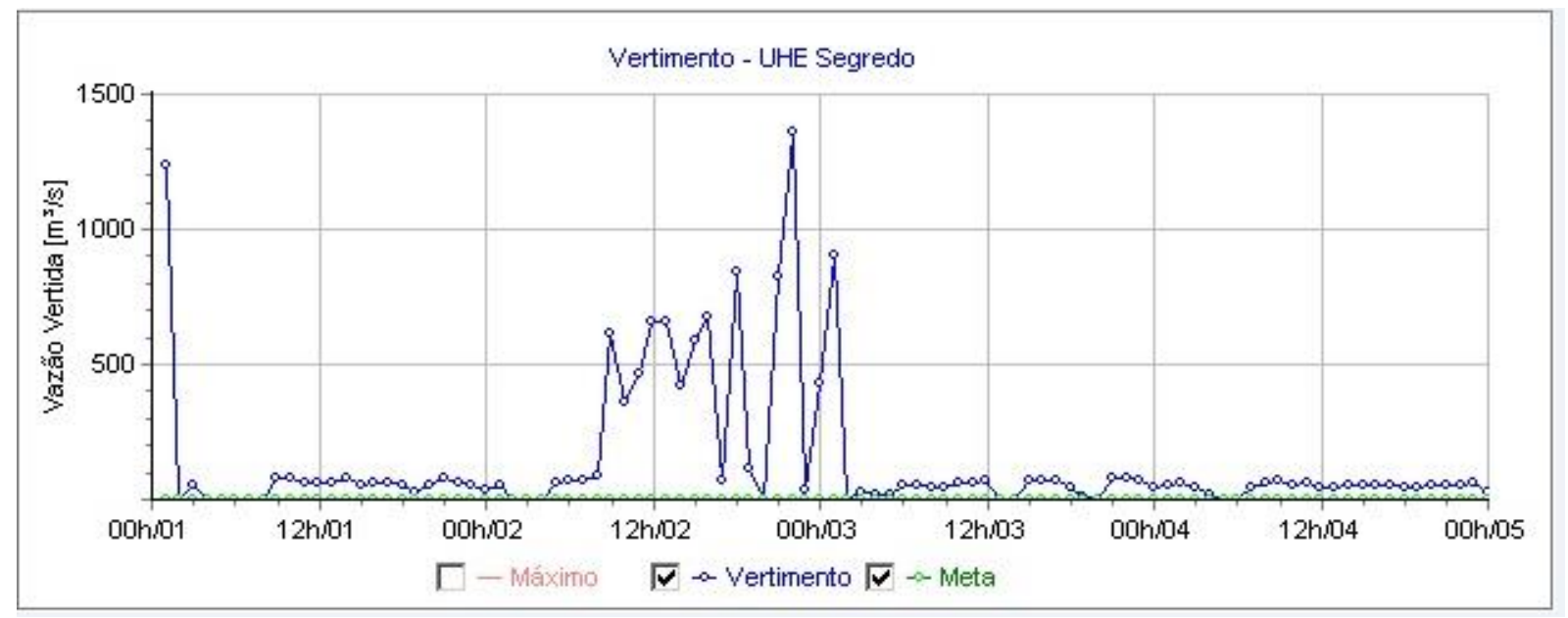

Figura 5.4 - Indicações da vazão na abertura do vertedouro da UHE Segredo

\section{UHE Salto Santiago}

A figura 5.5 indica como consequência do vertimento programado de até $1100 \mathrm{~m} / \mathrm{s}$ sendo necessário a continuidade do vertimento. 


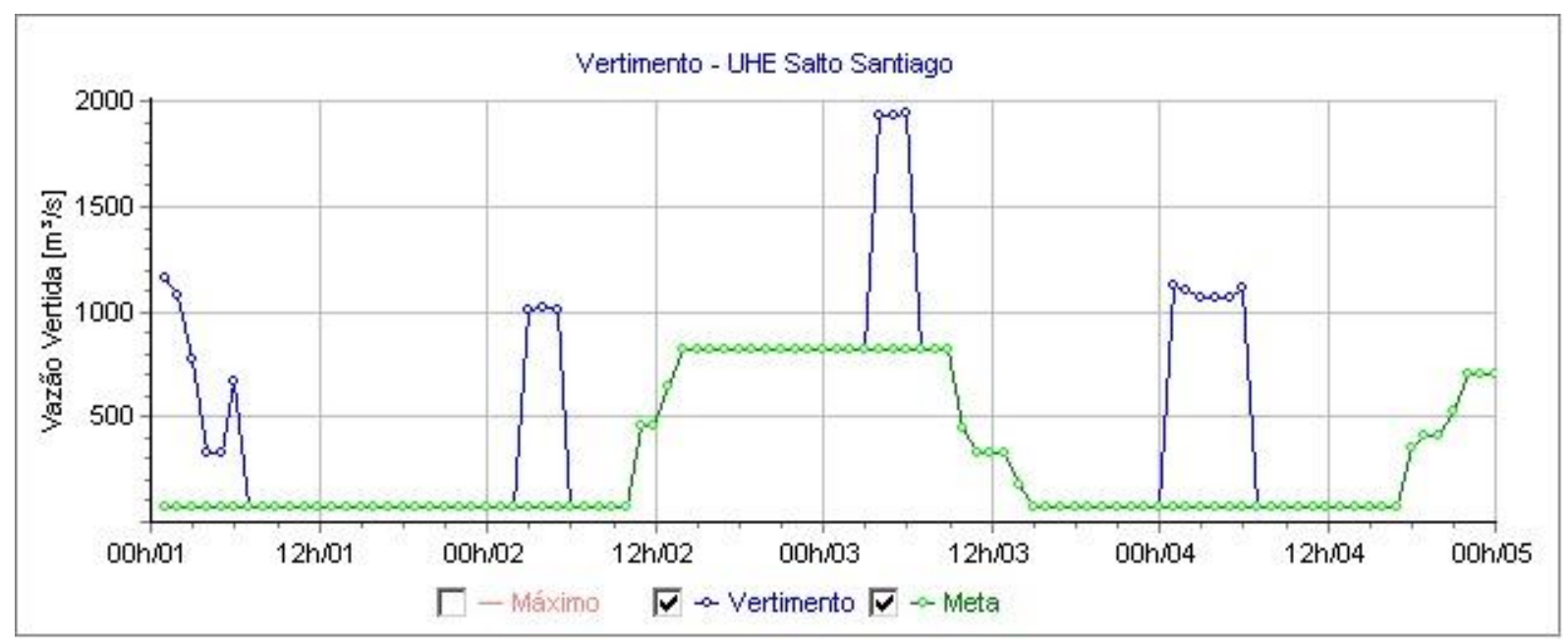

Figura 5.5 - Indicações da vazão na abertura do vertedouro da UHE Salto Santiago.

\section{UHE Salto Osório}

A figura 5.6 indica como consequência do vertimento programado de até $1400 \mathrm{~m} 3 / \mathrm{s}$ sendo necessário a continuidade do vertimento.

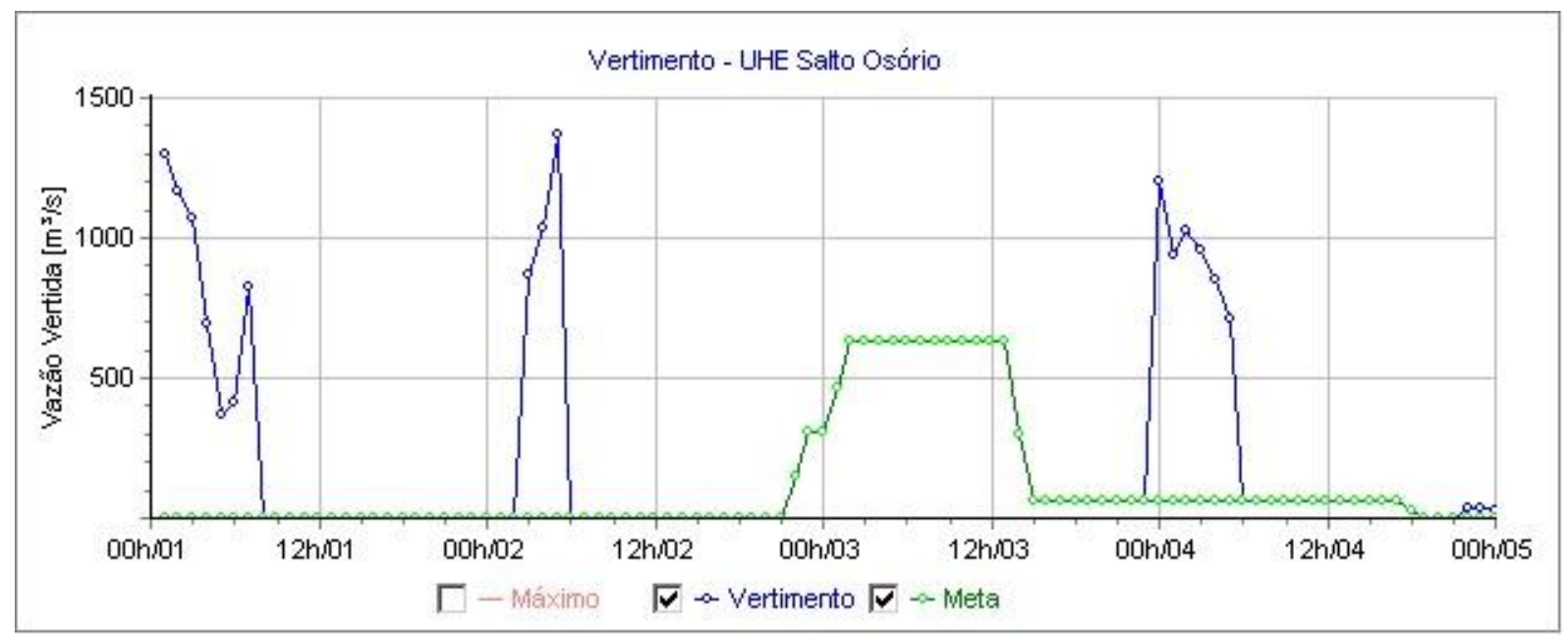

Figura 5.6 - Indicações da vazão na abertura do vertedouro da UHE Salto Osório. 


\section{UHE Salto Caxias}

A figura 5.7 indica como consequência do vertimento programado de até $1600 \mathrm{~m} / \mathrm{s}$ sendo necessário a continuidade do vertimento.

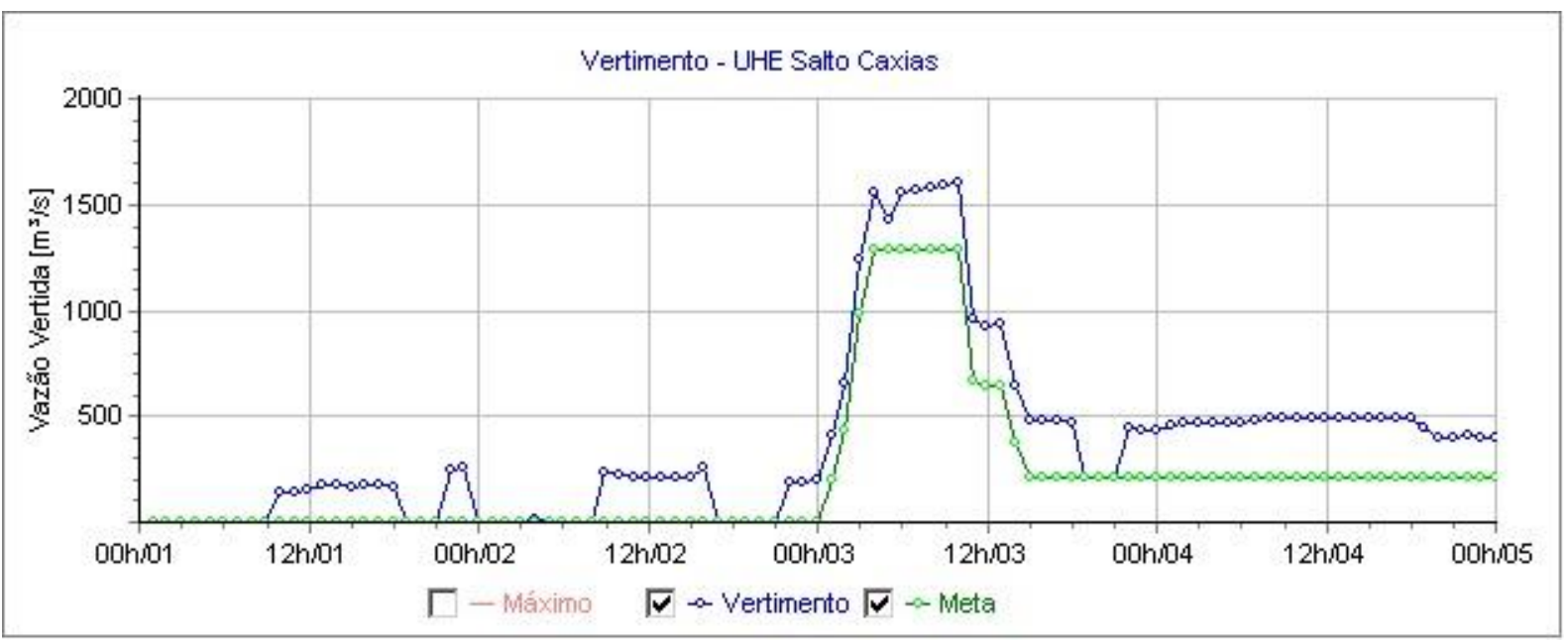

Figura 5.7 - Indicações da vazão na abertura do vertedouro da UHE Salto Caxias.

Na semana operativa de 01/02 a 05/02/2015 foi aplicado o método de rebaixamento dinâmico, porque foi sinalizado que o volume excelente era maior que o vazio no reservatório da UHE Foz do Areia.

Como consequência, foi necessário o vertimento escalonado em toda a bacia de forma que as usinas de Foz do Areia e Segredo atingissem o limite máximo no final do intervalo de 48 horas. 


\subsection{ANÁLISE DA SEMANA OPERATIVA DE 08/02 A 13/02/2015 COM TODA BACIA DO IGUAÇU ACIMA DE $80 \%$ VU}

Figura 5.8 ilustra o armazenamento dos reservatórios da bacia no início da semana de 08/02 a 13/02/2015 da simulação. O reservatório de Foz do Areia com 99,99\% VU (volume útil), Salto Segredo com 100\% VU, Salto Santiago com 100\% VU, Salto Osório com 93,38\% VU e Salto Caxias com $80,23 \%$ VU.

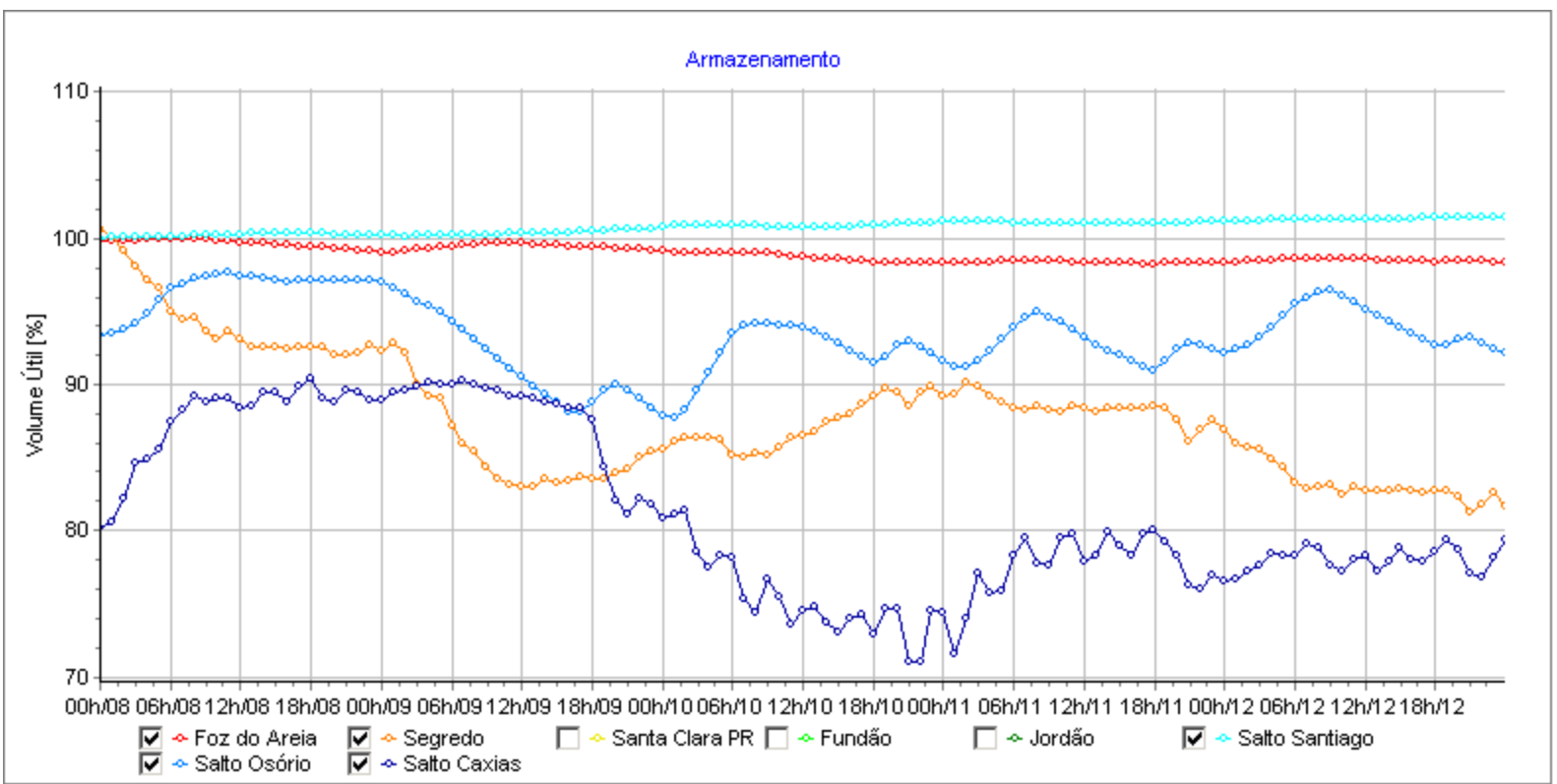

Figura 5.8 - Armazenamento dos reservatórios

Para esta condição, todas as usinas estão com os vertedouros abertos para que seja possível fazer controle de cheia na bacia. Nesta situação, a usina de Foz do Areia com vertimento inicial de 970 $\mathrm{m}^{3} / \mathrm{s}$.

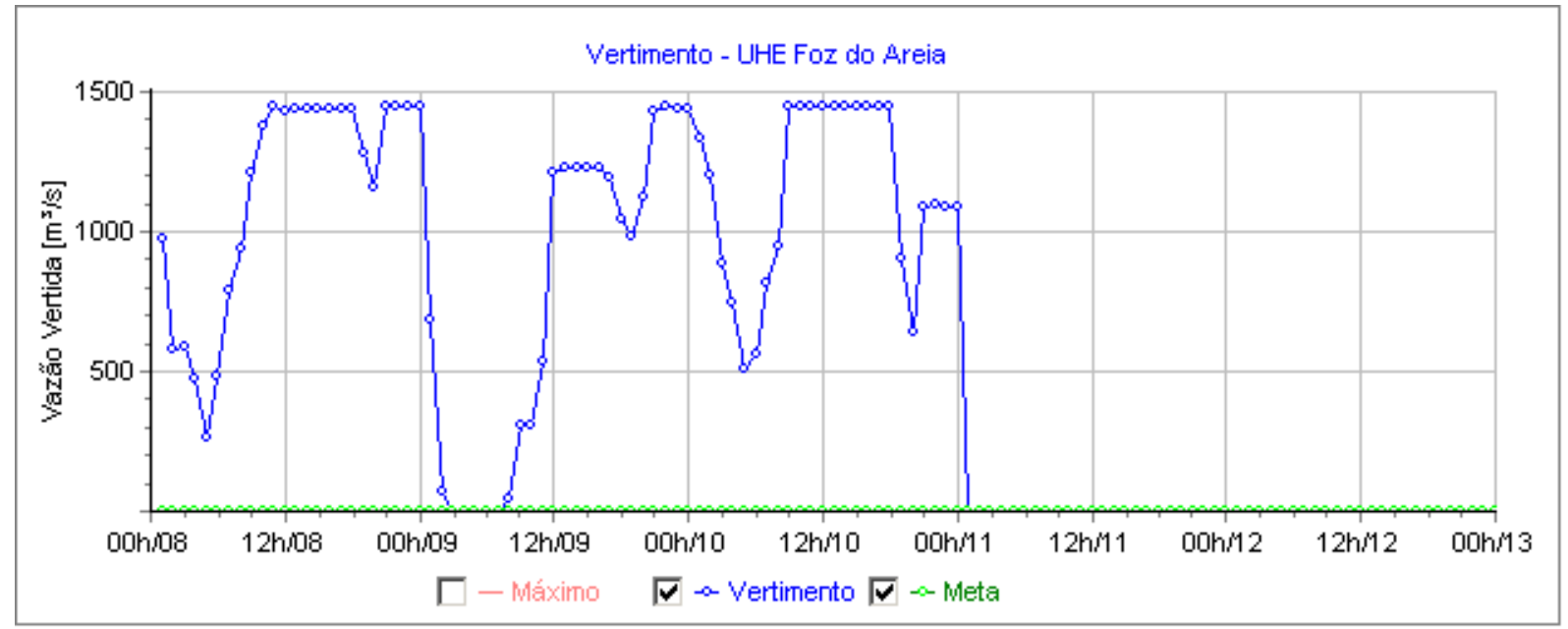

Figura 5.9 - Vazão do vertimento da UHE Foz do Areia 
A usina de Segredo com vertimento inicial de 1878 m³.

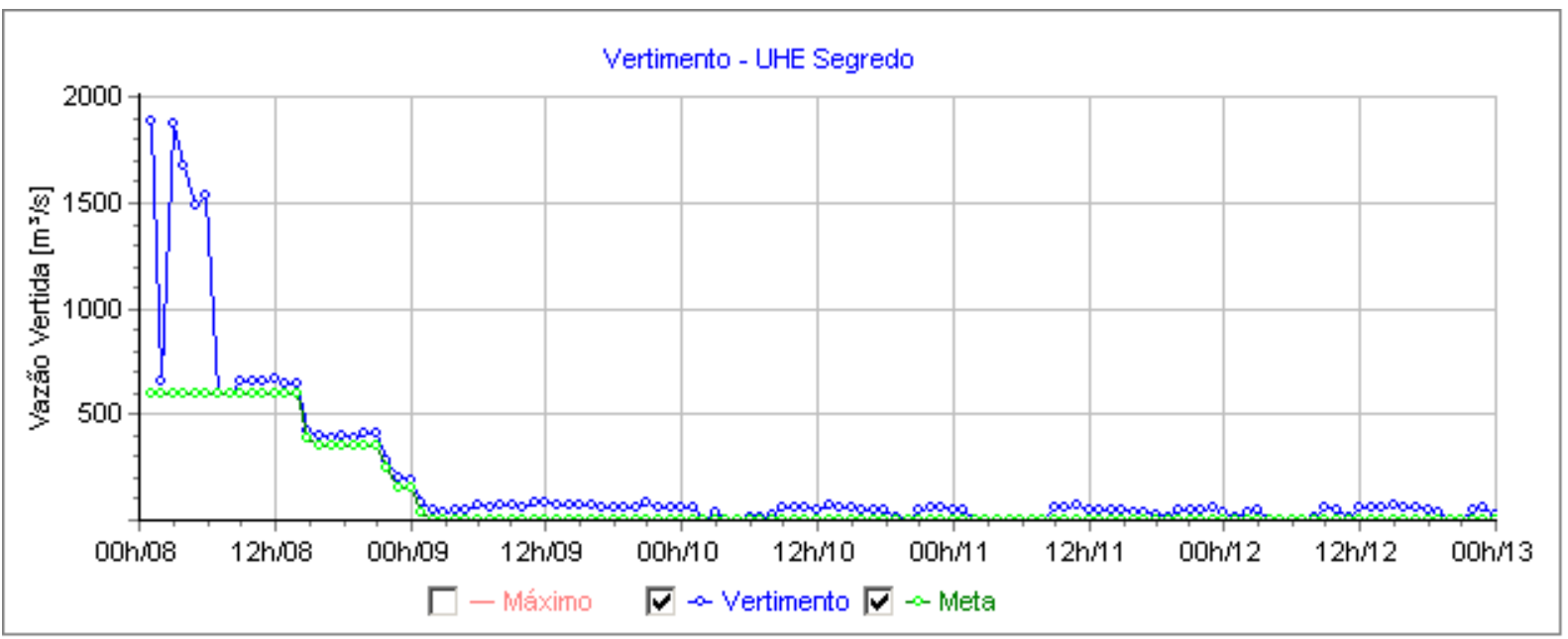

Figura 5.10 - Vazão do vertimento da UHE Segredo

A usina de Salto Santiago com vertimento inicial de 1770 m³/s.

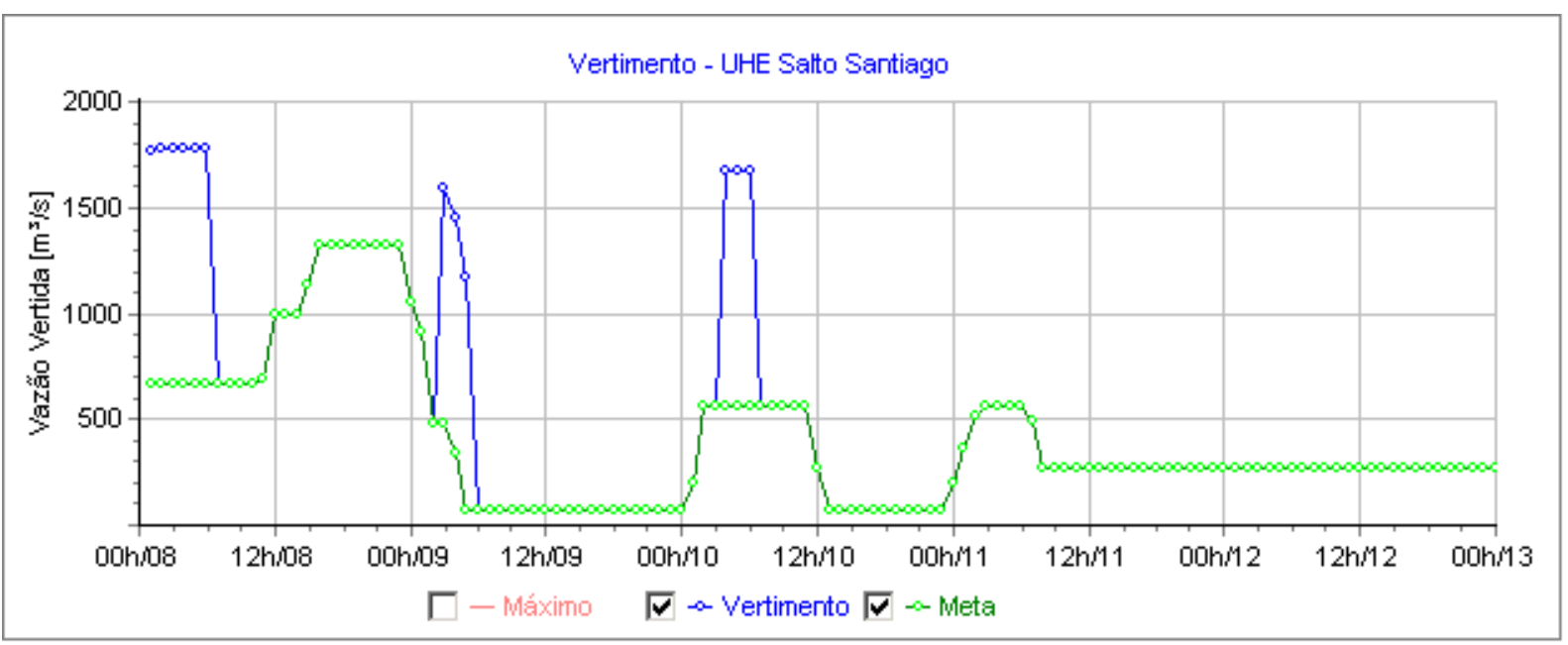

Figura 5.11 - Vazão do vertimento da UHE Salto Santiago 
A usina de Salto Osório com vertimento inicial de 1700 m³/s.

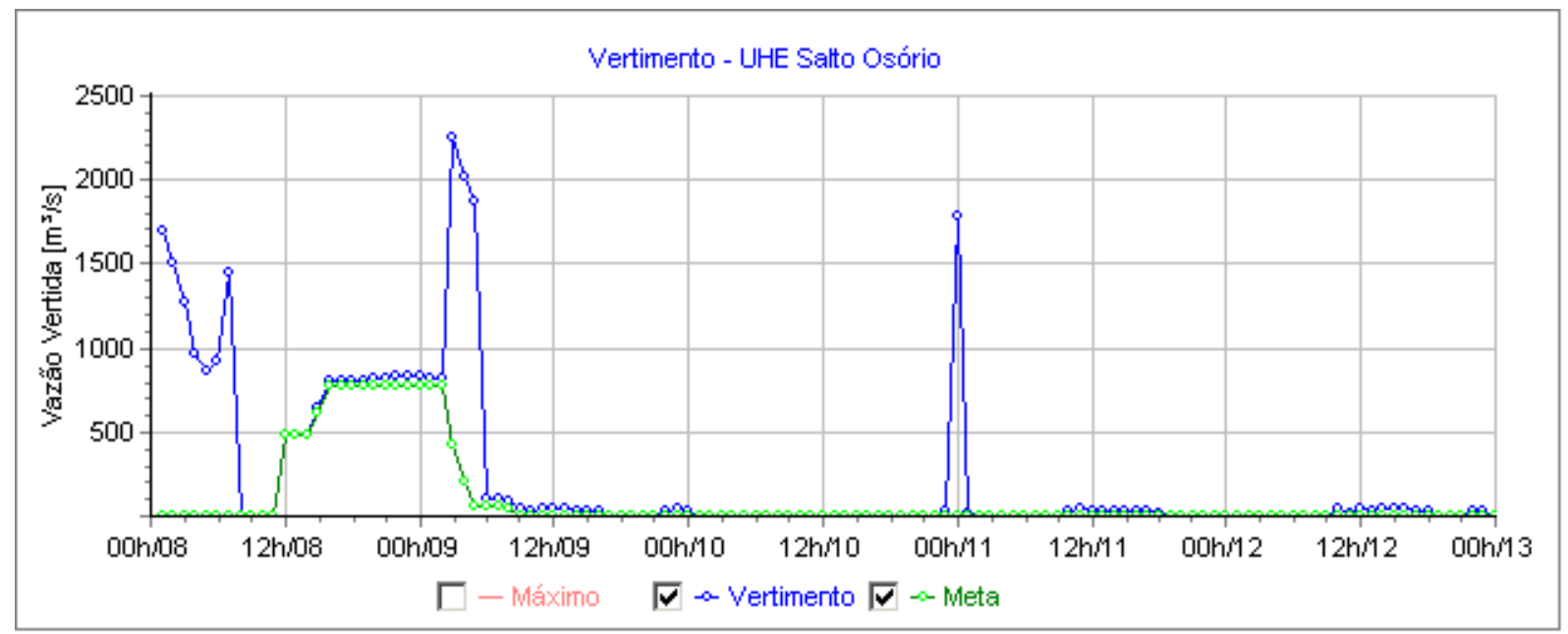

Figura 5.12 - Vazão do vertimento da UHE Salto Osório.

A usina de Salto Caxias com vertimento inicial de $212 \mathrm{~m} 3 / \mathrm{s}$.

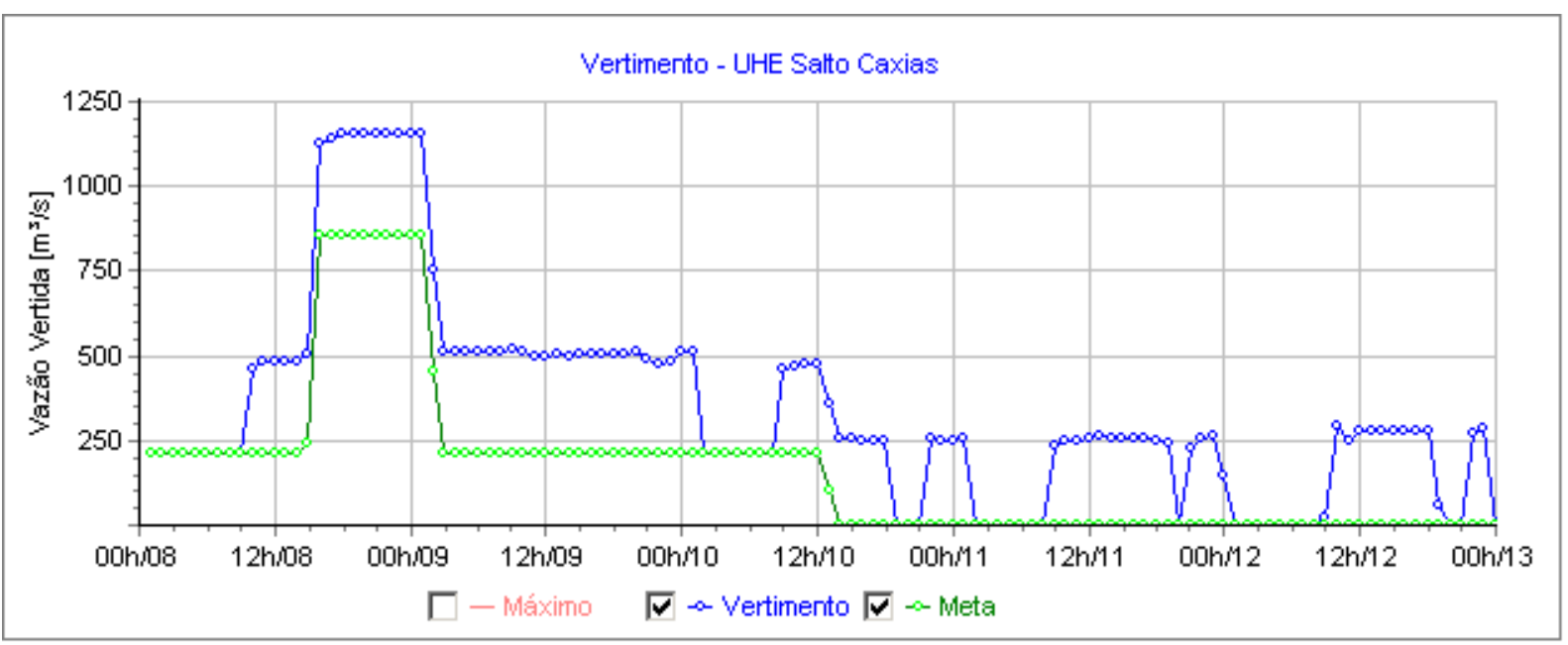

Figura 5.13 - Vazão do vertimento da UHE Salto Caxias.

Mesmo com toda a bacia vertendo, o volume excedente previsto está maior que o volume vazio no reservatório da UHE Foz do Areia, sendo a vazão (média) vertida de 607, 6 m³/s, tornando-se necessário o aumento do vertimento através do cálculo de rebaixamento dinâmico. 


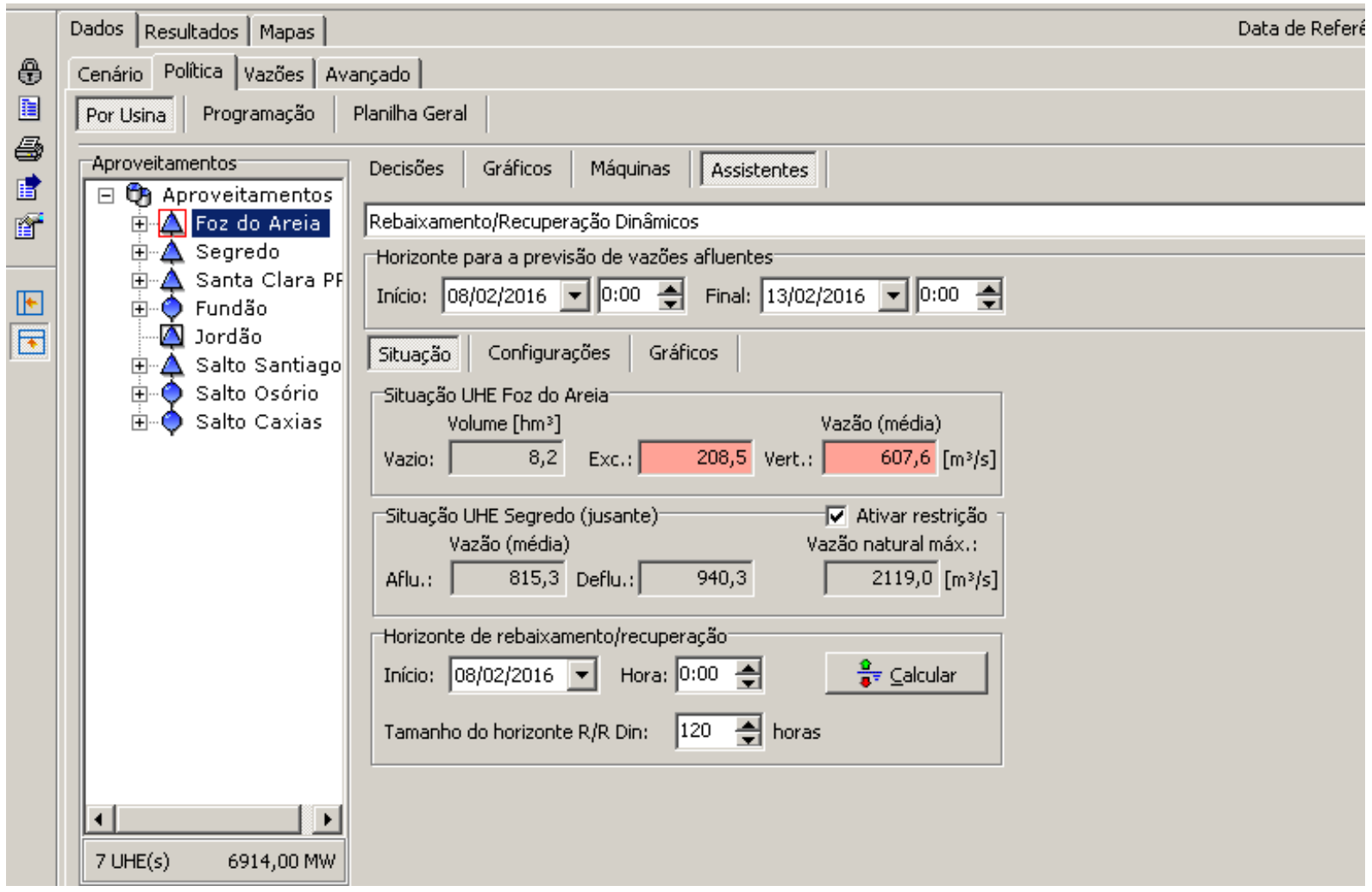

Figura 5.14 - Indicação do volume excedente previsto no horizonte de previsão de afluências.

Será indicado um horizonte de rebaixamento de 48 horas a partir do primeiro dia do horizonte de previsão, onde será confirmada a alteração da programação de vazões vertidas para o rebaixamento.

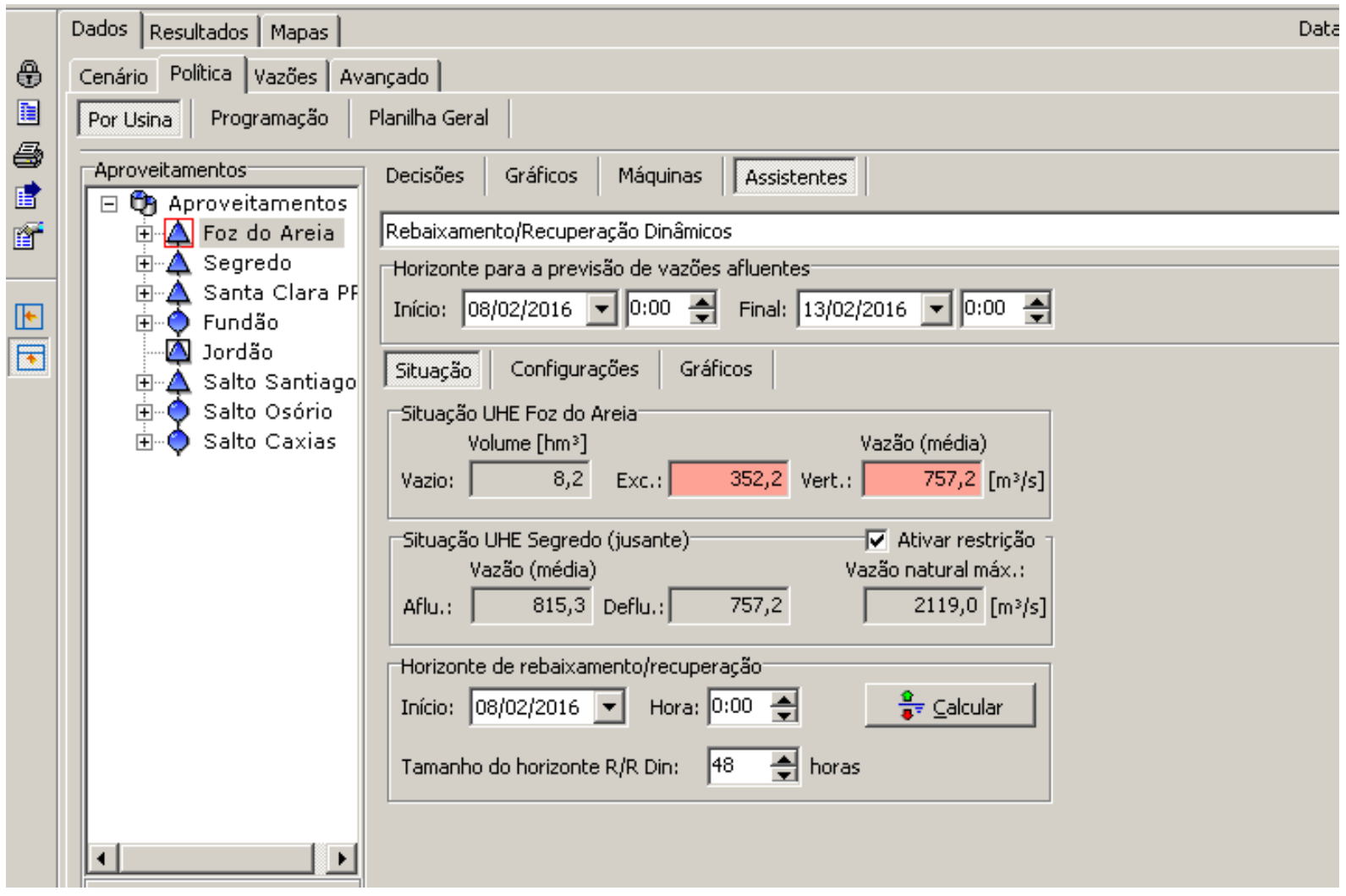

Figura 5.15 - Indicação do rebaixamento dinâmico de 48 horas. 
Pode-se observar a trajetória das 48 horas do horizonte de estudo o rebaixamento com o aumento do vertimento da UHE Foz do Areia de $970 \mathrm{~m}^{3} / \mathrm{s}$ para $2000 \mathrm{~m}^{3} / \mathrm{s}$, sendo necessário um aumento de vazão às $02 \mathrm{~h} 00$ do dia 09/02 com $3.245 \mathrm{~m}^{3} \mathrm{~s}$.

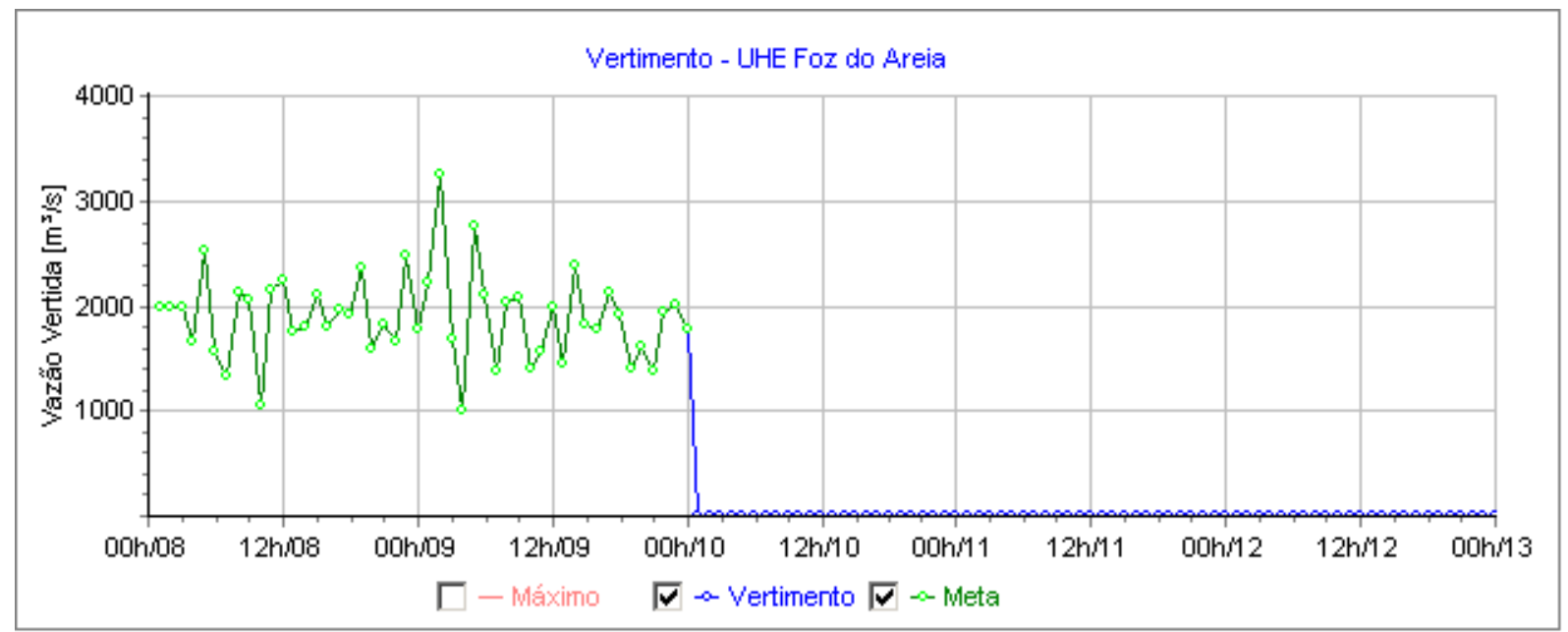

Figura 5.16 - Indicações da vazão do aumento do vertimento da UHE Foz do Areia

O vertimento da UHE Segredo passa de 1878 para $2220 \mathrm{~m} 3 / \mathrm{s}$ até o fechamento às $00 \mathrm{~h} 00$ do dia 10/02.

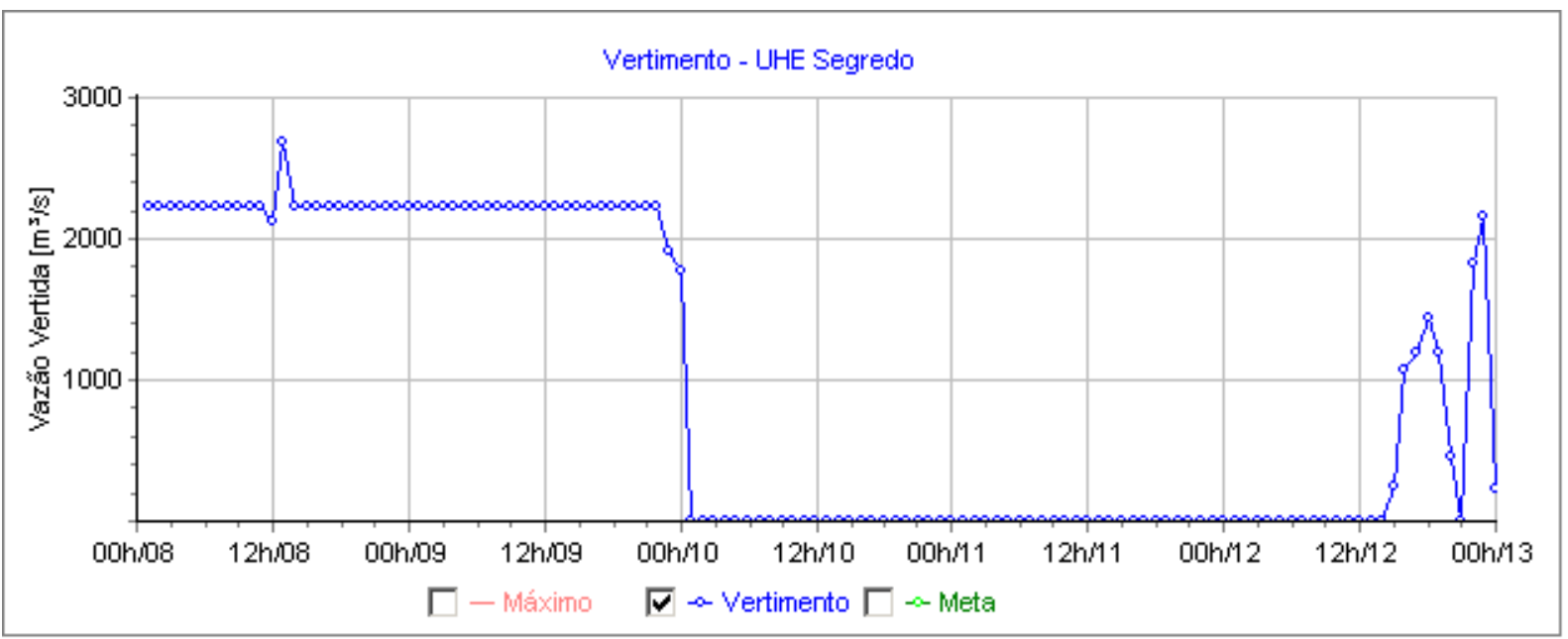

Figura 5.17 - Indicações da vazão do aumento do vertimento da UHE Segredo. 


\subsection{ANÁLISE DA SEMANA OPERATIVA DE 13/07 A 17/07/15 COM PREVISÃO DE ALTAS PRECIPITAÇÕES}

Como dados, para realização de simulações, foram utilizados os relativos à semana operativa de 13/07/2015 a 17/07/2015. Foi considerada para esta semana ocorrência de altas precipitações em toda a bacia do Iguaçu.

A Fig. 5.18 ilustra o armazenamento dos reservatórios da bacia do Iguaçu no início da simulação. O reservatório de Foz do Areia estava com 87,79\% VU (VU significa volume útil), Salto Segredo com 99,59\% VU, Salto Santiago com 64,61\% VU, Salto Osório com 93,37\% VU e Salto Caxias com $86,39 \%$ VU.

Com esses volumes, todos os reservatórios estavam vertendo, com exceção da UHE Foz do Areia e UHE Salto Santiago. O reservatório de Foz do Areia fica na cabeceira da bacia e o reservatório de Salto Santiago fica no meio da cascata.

Foi simulada uma elevação da precipitação à montante da UHE Foz do Areia, onde o seu volume útil chegaria com $92 \%$ da sua capacidade no intervalo de 8 horas. O simulador hidráulico sinalizou a abertura do vertedouro com $92 \%$ e com o aumento do vertimento da UHE Segredo com antecedência de 6 horas. O reservatório da UHE Salto Santiago, logo à jusante, pôde acumular de 64\% até $80 \%$. Com isto, foi possível receber o volume de água e acumular essa água, defluindo o mínimo possível para o reservatório logo à jusante.

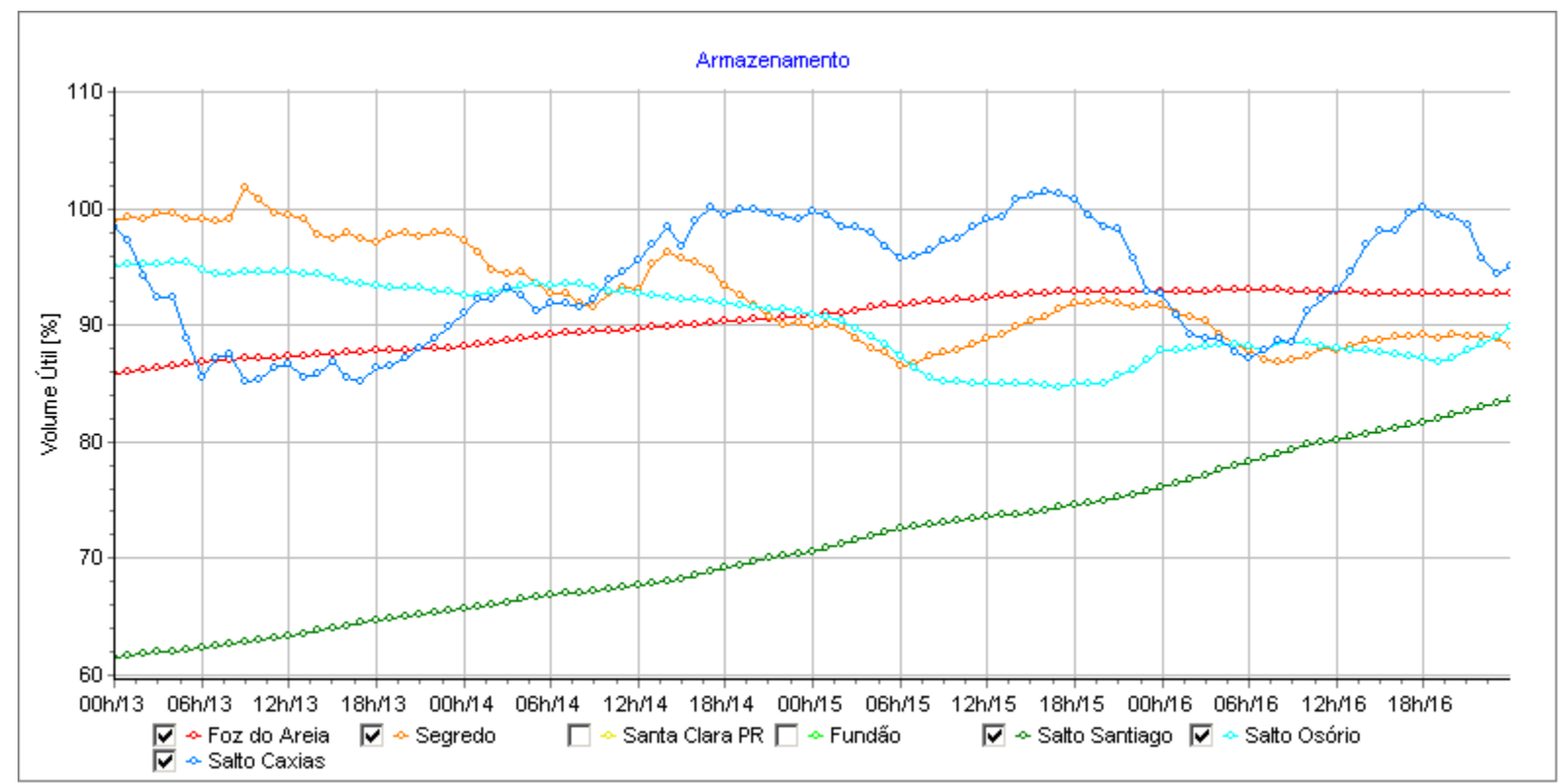

Figura 5.18 - Armazenamento dos reservatórios

Diante disso, os reservatórios de Salto Osório e Salto Caxias permaneceram com vertimentos extras. 
O simulador hidráulico sinalizou o rebaixamento no reservatório de Foz do Areia através da abertura do vertedouro quando o volume útil chegou a $92 \%$ com vazão defluente de $133 \mathrm{~m} 3 / \mathrm{s}$ por volta de 11 h00 no dia 15/07/2015, conforme indicado nos gráficos da Figura 5.3.

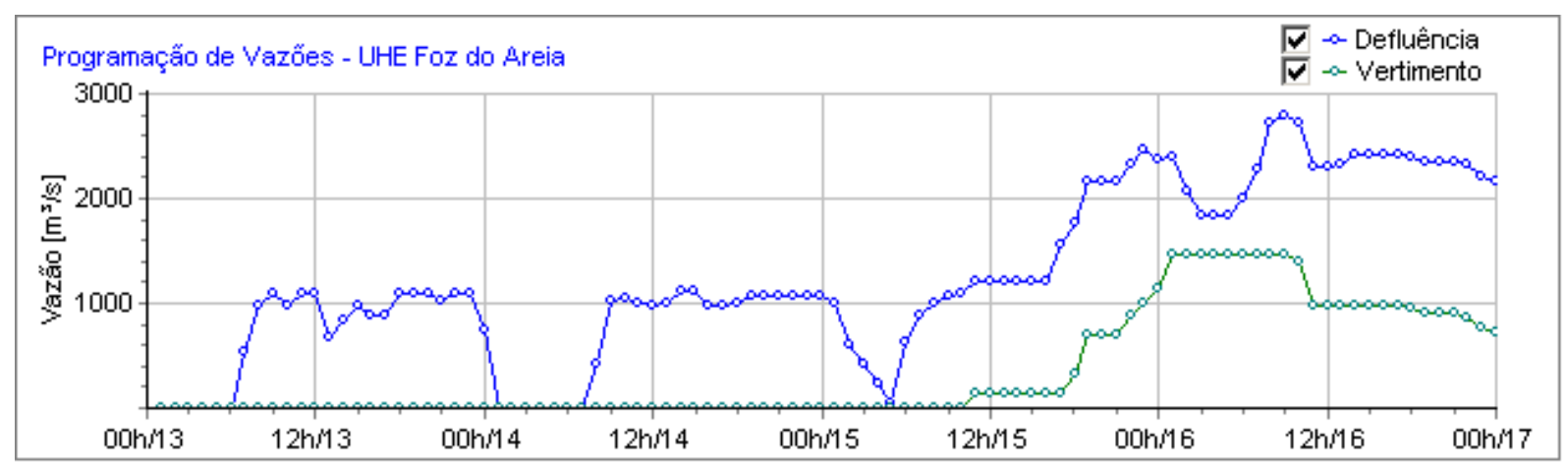

Figura 5.19 - Indicações da vazão na abertura do vertedouro da UHE Foz do Areia (escala na horizontal corresponde a divisões por meio-dia)

Com a abertura do vertedouro de Foz do Areia, o simulador indicou um vertimento no reservatório de Salto Santiago, por volta de $18 \mathrm{~h} 00$, no dia $17 / 07$ com $90 \%$ e vazão de $63 \mathrm{~m} / \mathrm{s}$ conforme ilustração de curvas na Figura 5.20.

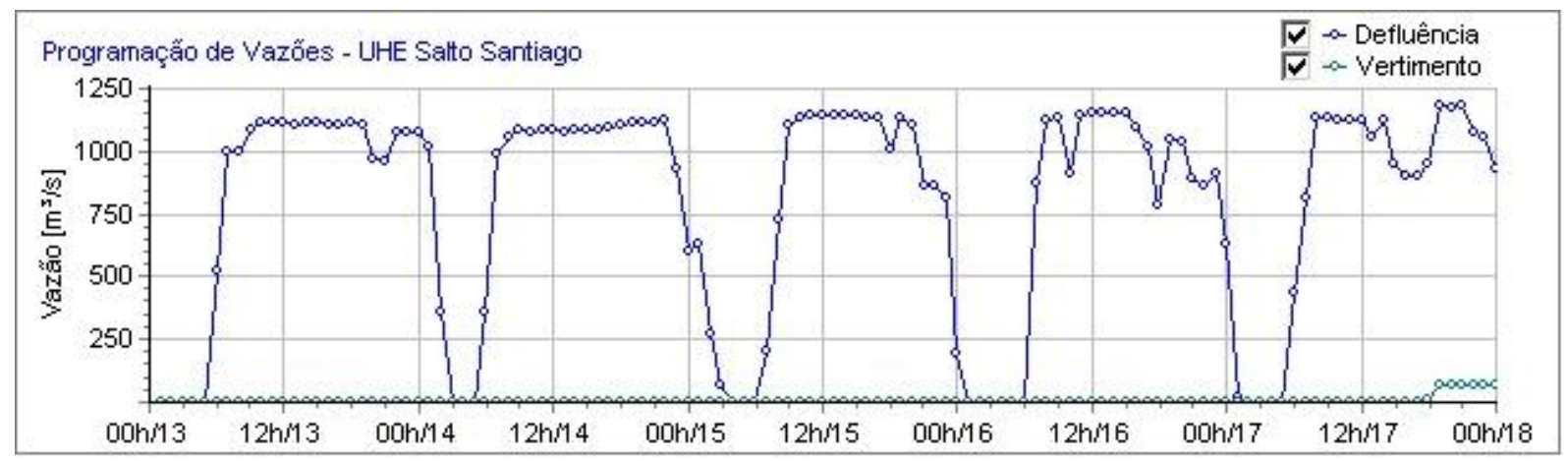

Figura 5.20 - Indicações de vazão na abertura do vertedouro da UHE Salto Santiago (escala na horizontal corresponde a divisões por meio-dia)

Desta forma, foi utilizado o método de rebaixamento para sinalizar o quanto o reservatório de Foz do Areia poderia acumular água. Assim, foi possível se avaliar o comprometimento das estruturas do reservatório à jusante e determinar o aumento da abertura dos reservatórios, uma vez que tanto Foz do Areia, quanto Salto Santiago, estavam com o volume útil acima de $80 \%$. 


\subsection{ANÁLISE DA SEMANA OPERATIVA DE 07/12 A 12/12/2015 COM INDISPONIBILIDADE DE UMA UNIDADE GERADORA NA UHE FOZ DO AREIA.}

A Figura 5.21 ilustra o armazenamento dos reservatórios da bacia no início da simulação. O reservatório de Foz do Areia com 97\% VU (volume útil), Salto Segredo com 100\% VU, Salto Santiago com 98\% VU, Salto Osório com 97\% VU e Salto Caxias com 99\% VU.

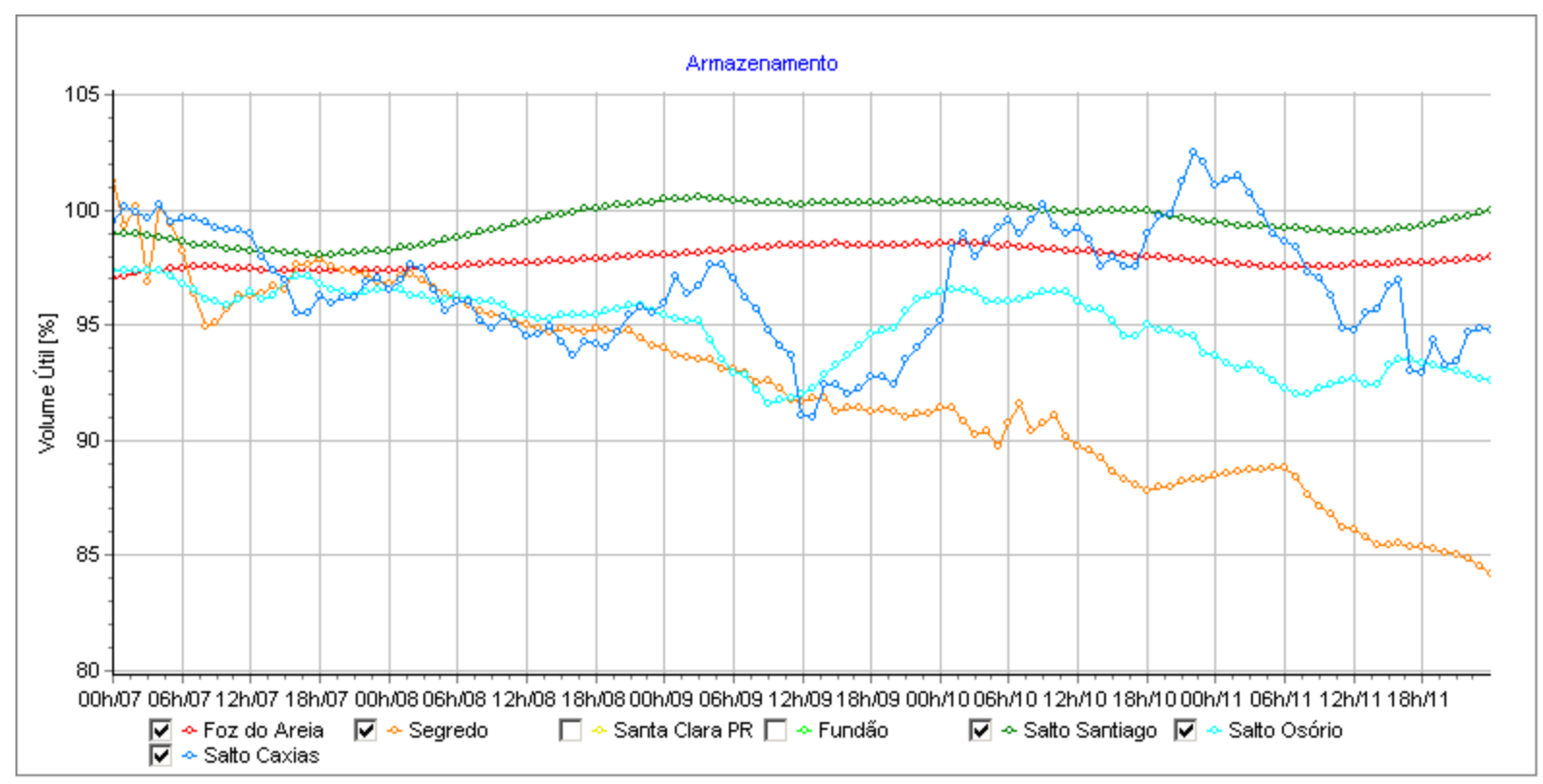

Figura 5.21 - Armazenamento dos reservatórios

A usina Foz do Areia estava com geração programada de 700 MW às $00 h 00$ do dia 07 e com 4 unidades geradoras disponíveis para a operação. Esta geração é baixa no início do dia de uma segunda-feira devido ser carga leve e com isso não há demanda suficiente para ser necessária toda a geração da usina. Às 12:00h a geração programada já chega a 1600 MW.

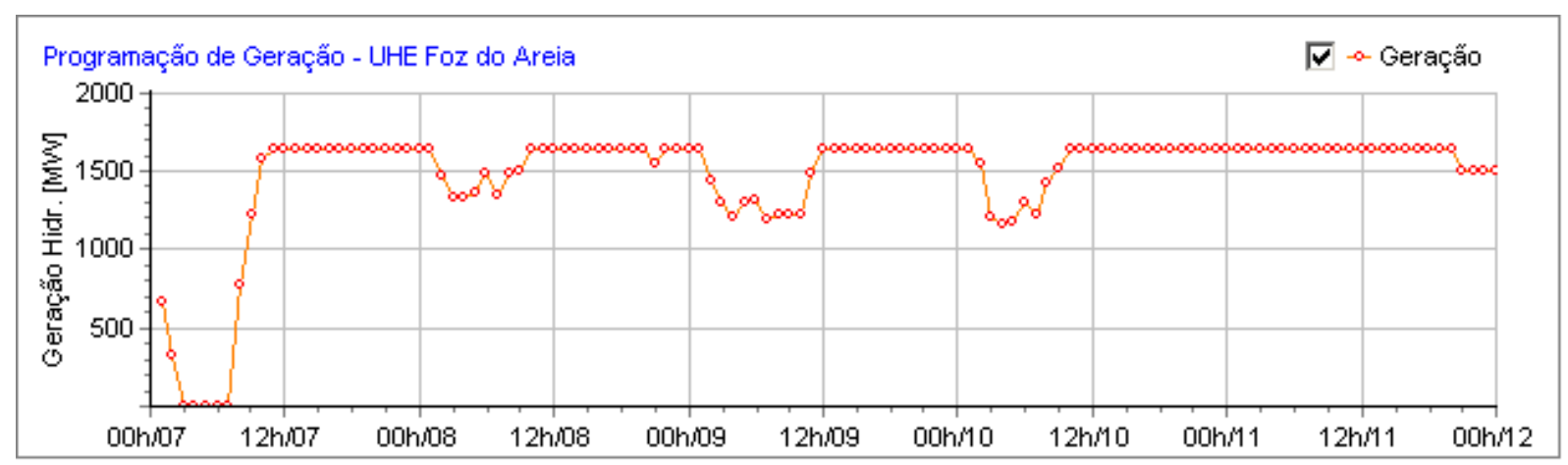

Figura 5.22 - Programação de geração da UHE Foz do Areia. 
Com $97 \%$ VU a usina estava programada com 700 m³/s de defluência, e com 1000 m³/s de vertimento. Usina operando praticamente a fio d'água.

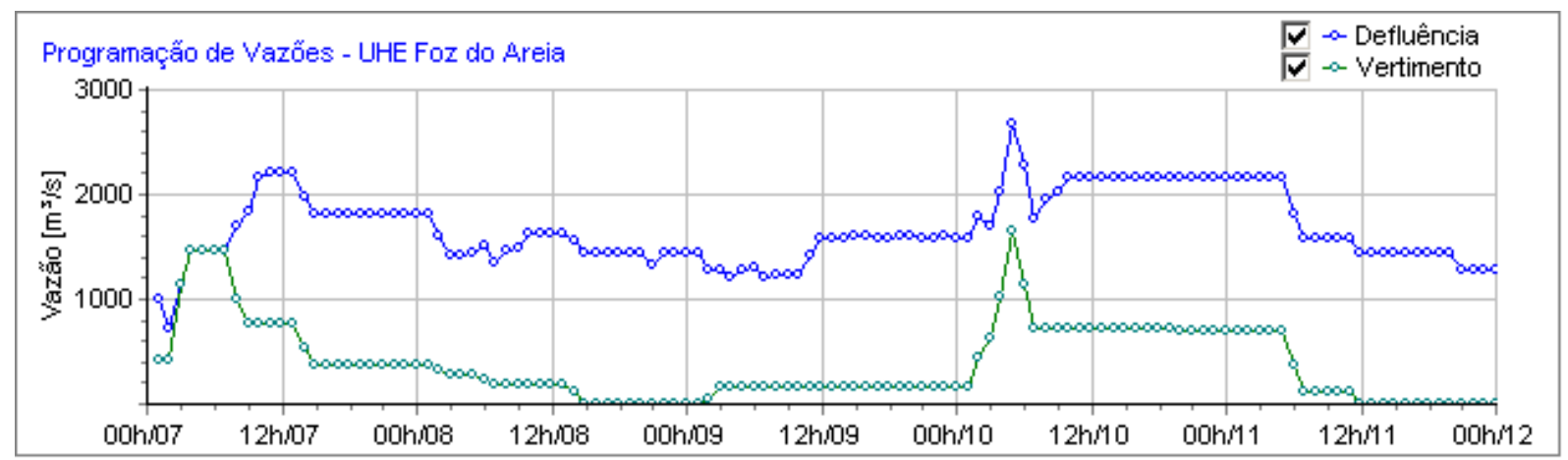

Figura 5.23 - Programação de defluência/vertimento da UHE Foz do Areia.

A usina de Segredo com 4 unidades geradoras disponíveis para a operação e com geração programada de $730 \mathrm{MW}$ às $00 \mathrm{~h} 00$ do dia 07/12 na carga leve devido baixa demanda na região Sul e com geração de 1100 MW às 12:00 do mesmo dia.

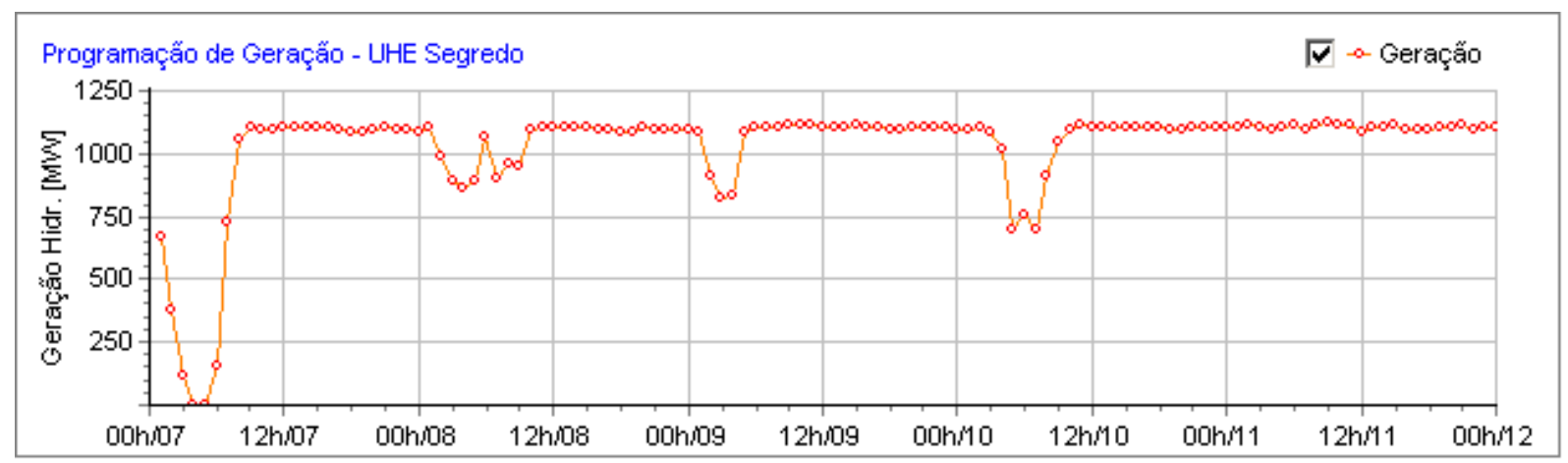

Figura 5.24 - Programação de geração da UHE Segredo.

Com 100\% VU a usina estava programada com 1900 m³/s de defluência, e com 1000 m³/s de vertimento às 00 h00 do dia 07/12.

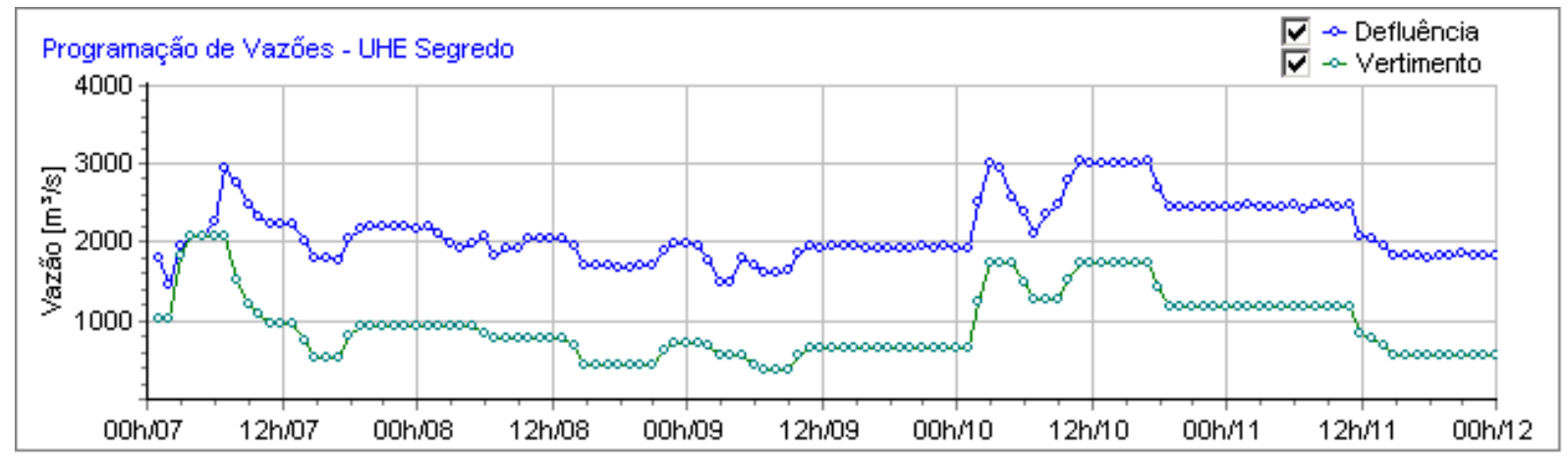

Figura 5.25 - Programação de defluência/vertimento da UHE Segredo. 
A usina de Salto Santiago com 4 unidades geradoras disponíveis para a operação e com geração programada de $900 \mathrm{MW}$ às $00 \mathrm{~h} 00$ do dia $07 / 12$ na carga leve devido baixa demanda na região Sul e com geração de 1400 MW às 00h00 do dia 09/12.

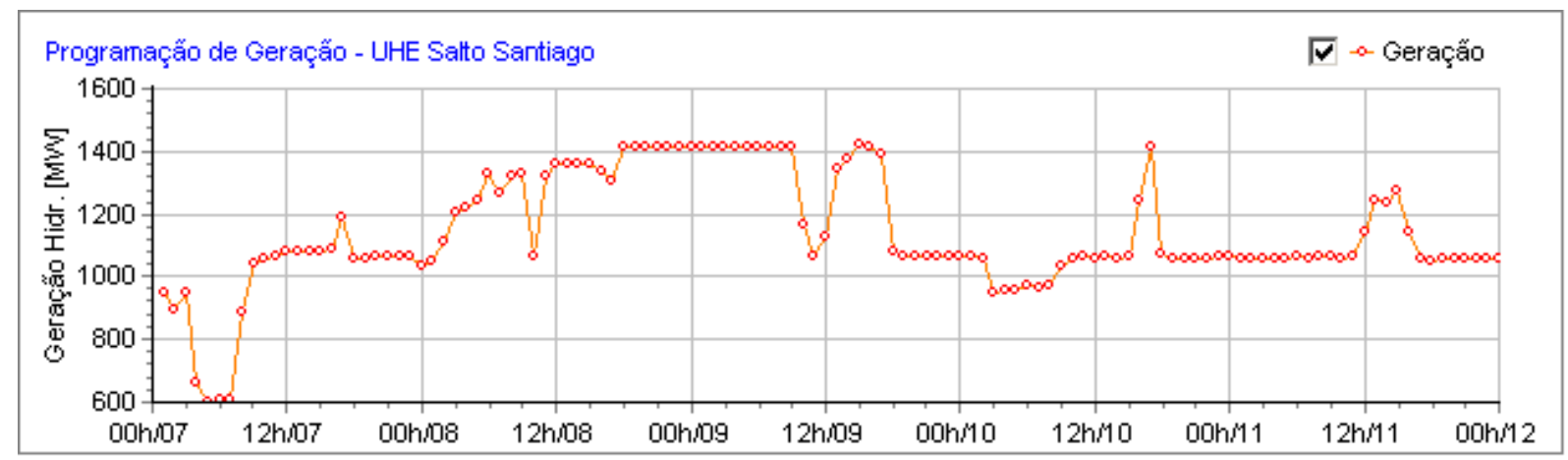

Figura 5.26 - Programação de geração da UHE Salto Santiago.

Com $98 \%$ VU a usina estava programada com $4000 \mathrm{~m}^{3} / \mathrm{s}$ de defluência, e com $3000 \mathrm{~m} / \mathrm{s}$ de vertimento às $00 \mathrm{~h} 00$ do dia 07/12.

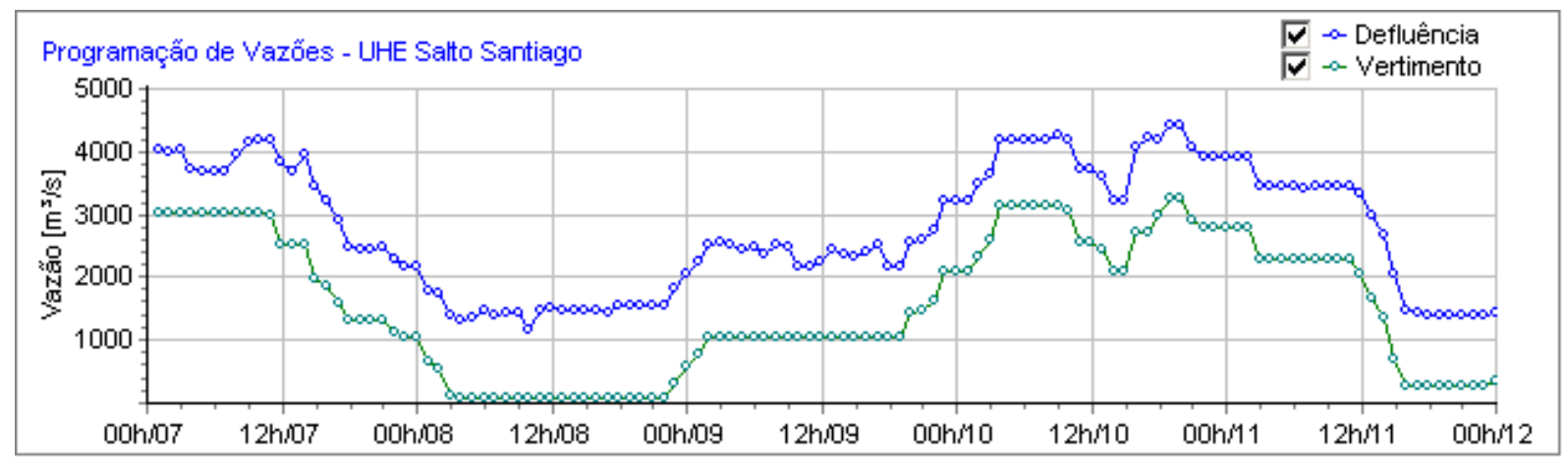

Figura 5.27 - Programação de defluência/vertimento da UHE Salto Santiago.

A usina de Salto Osorio com 6 unidades geradoras disponíveis para a operação e com geração programada de $800 \mathrm{MW}$ às $00 \mathrm{~h} 00$ do dia $07 / 12$ na carga leve.

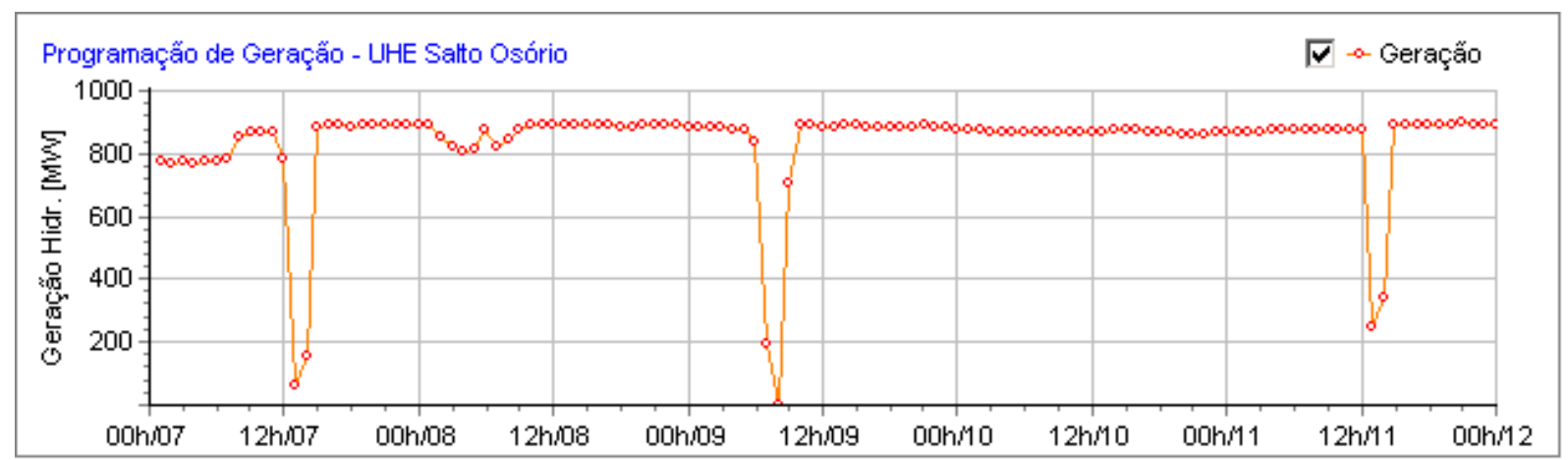

Figura 5.28 - Programação de geração da UHE Salto Osório. 
Com $97 \%$ VU a usina estava programada com $4100 \mathrm{~m}^{3} / \mathrm{s}$ de defluência, e com $3000 \mathrm{~m} / 3 \mathrm{~s} \mathrm{de}$ vertimento às 00 h00 do dia 07/12.

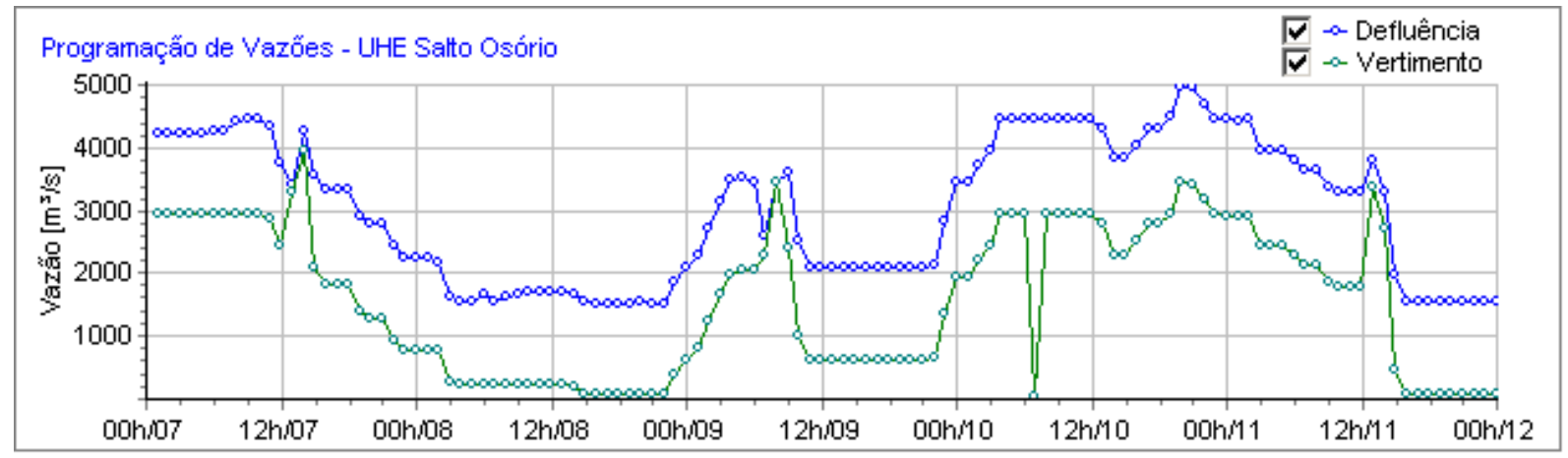

Figura 5.29 - Programação de defluência/vertimento da UHE Salto Osório.

A usina de Salto Osorio com 4 unidades geradoras disponíveis para a operação e com geração programada de $920 \mathrm{MW}$ às $00 \mathrm{~h} 00$ do dia $07 / 12$ na carga leve.

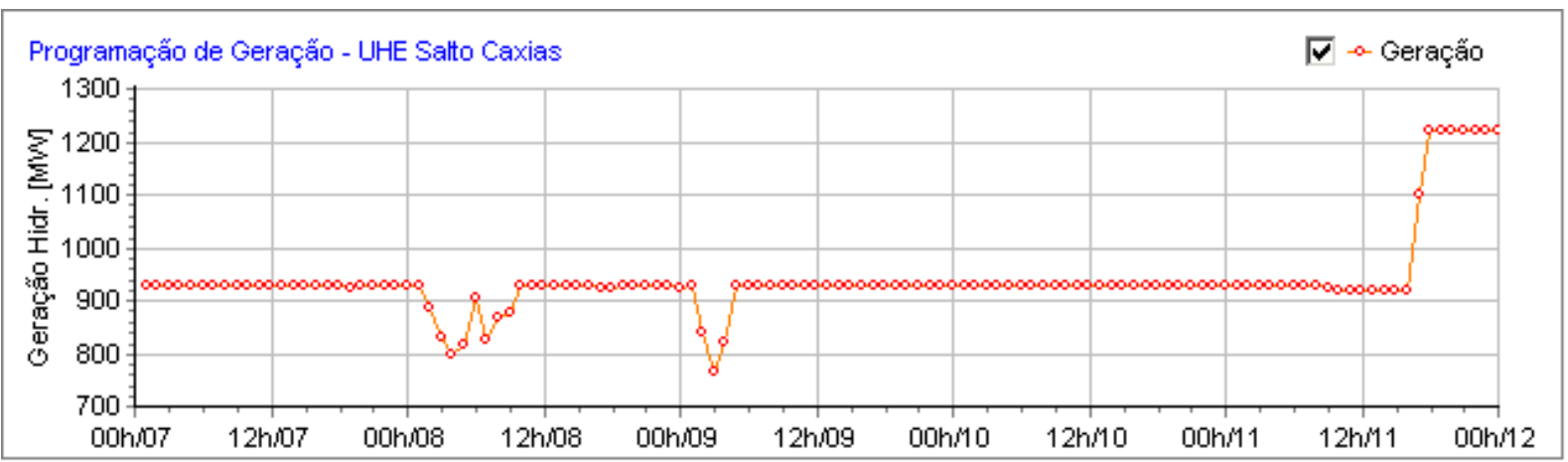

Figura 5.30 - Programação de geração da UHE Salto Caxias.

Com $99 \%$ VU a usina estava programada com $4600 \mathrm{~m}^{3} / \mathrm{s}$ de defluência, e com $3100 \mathrm{~m}^{3} / \mathrm{s} \mathrm{de}$ vertimento às 00 h00 do dia 07/12. 


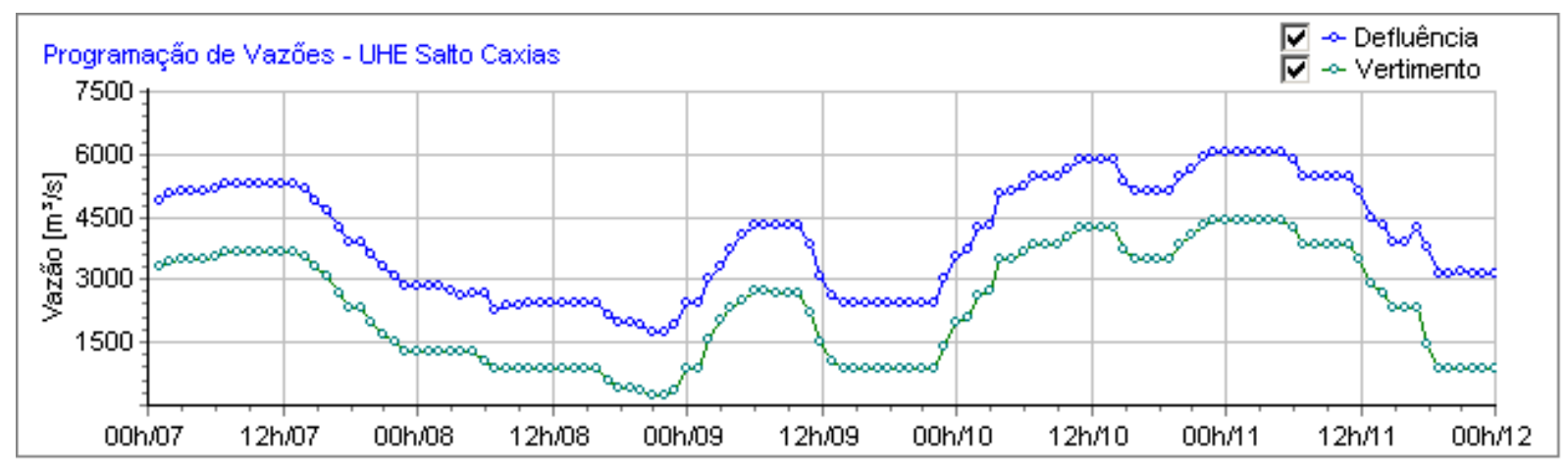

Figura 5.31 - Programação de defluência/vertimento da UHE Salto Caxias.

O volume excedente previsto está maior que o volume vazio no reservatório da UHE Foz do Areia, sendo a vazão (média) vertida com $476,2 \mathrm{~m}^{3} / \mathrm{s}$, o qual será alvo do cálculo de rebaixamento dinâmico e com a indisponibilidade de 1 (uma) unidade geradora na UHE Foz do Areia e na UHE Segredo.

Será indicado um horizonte de rebaixamento de 100 horas a partir do primeiro dia do horizonte de previsão, onde será confirmada a alteração da programação de vazões vertidas para o rebaixamento.

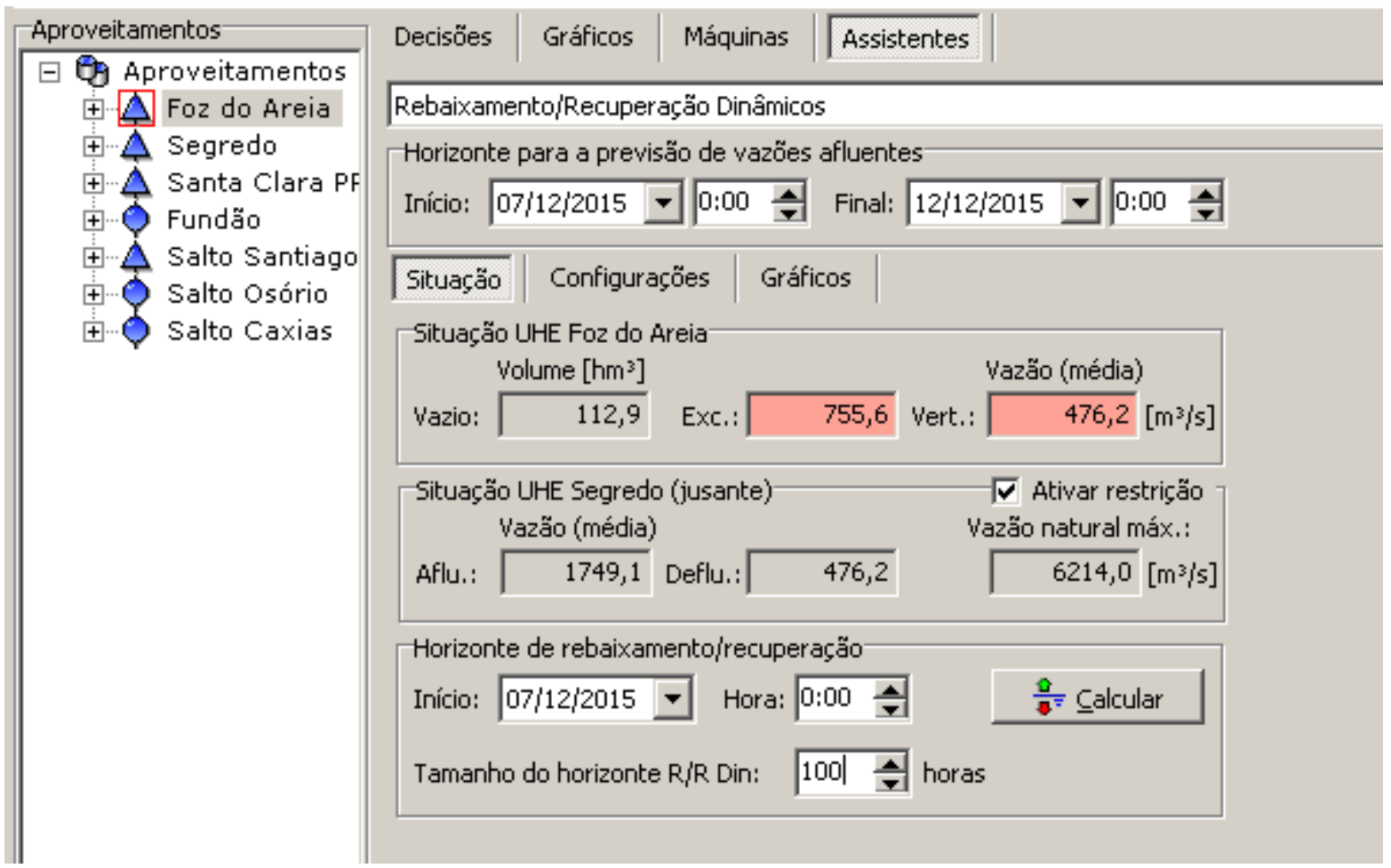

Figura 5.32 - Indicação do rebaixamento dinâmico das 100 horas. 
Conforme as Figuras 43 a 48 e a Tabela 5.2, são comparados os valores de geração, defluência e vertimento das UHEs Foz do Areia e Segredo com 3 e 4 unidades geradora respectivamente, onde ocorreu aumento da defluência nas duas usinas e aumento do vertimento na UHE Segredo.

Tabela 5.2 - Tabela comparativa com indisponibilidade de unidades geradoras.

\begin{tabular}{|c|c|c|c|c|c|c|}
\hline \multirow{2}{*}{ Usinas } & \multicolumn{3}{|c|}{4 unidades geradoras disponíveis } & \multicolumn{3}{c|}{3 unidades disponíveis } \\
\cline { 2 - 7 } & Geração & Defluência & Vertimento & Geração & Defluência & Vertimento \\
\hline UHE Foz do Areia & $700 \mathrm{MW}$ & $700 \mathrm{~m}^{3} / \mathrm{s}$ & $1000 \mathrm{~m}^{3} / \mathrm{s}$ & $730 \mathrm{MW}$ & $1900 \mathrm{~m}^{3} / \mathrm{s}$ & $1000 \mathrm{~m}^{3} \mathrm{~s}$ \\
\hline UHE Segredo & $700 \mathrm{MW}$ & $1000 \mathrm{~m}^{3} / \mathrm{s}$ & $1000 \mathrm{~m}^{3} / \mathrm{s}$ & $660 \mathrm{MW}$ & $1900 \mathrm{~m}^{3} / \mathrm{s}$ & $1800 \mathrm{~m}^{3} \mathrm{~s}$ \\
\hline
\end{tabular}

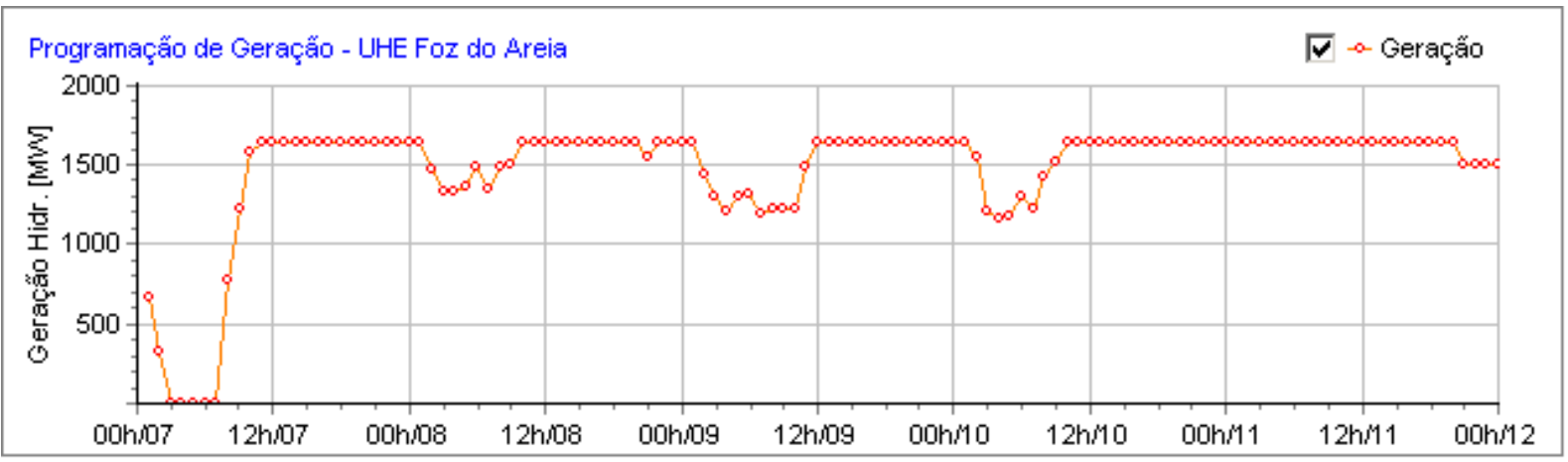

Figura 5.33 - Programação de geração da UHE Foz do Areia.

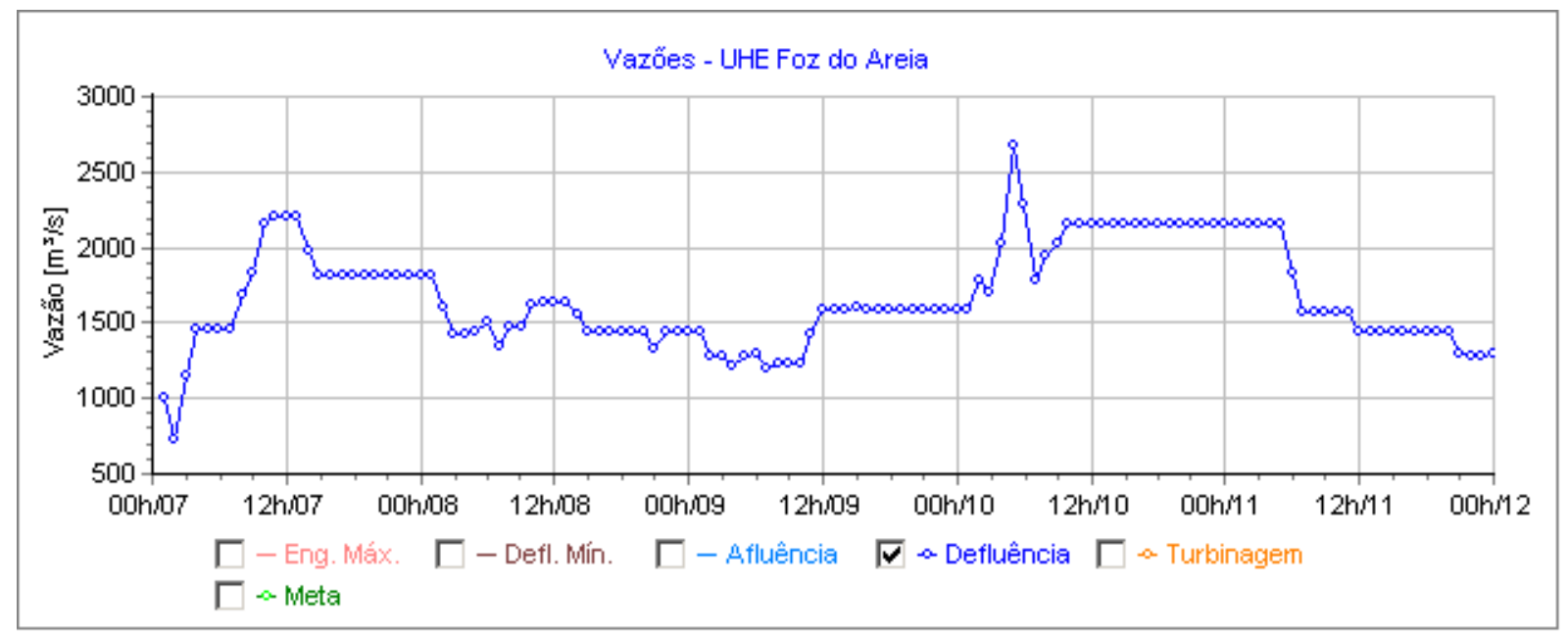

Figura 5.34 - Programação de defluência da UHE Foz do Areia. 


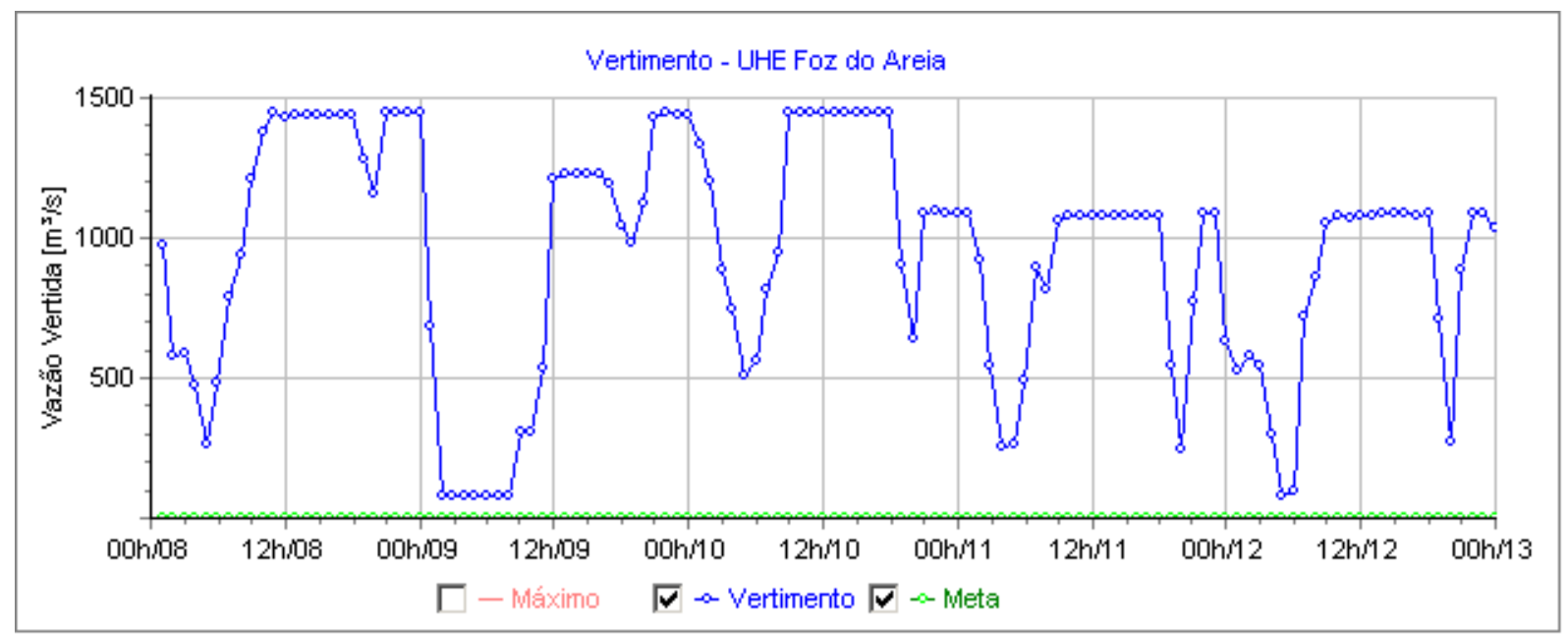

Figura 5.35 - Programação de vertimento da UHE Foz do Areia.

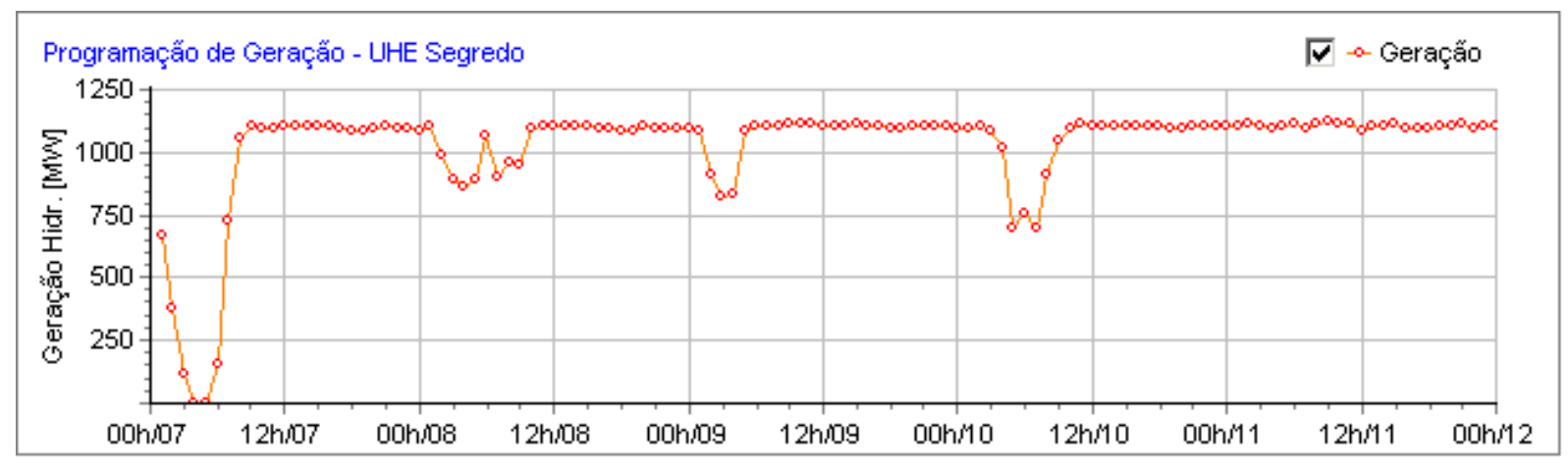

Figura 5.36 - Programação de geração da UHE Segredo.

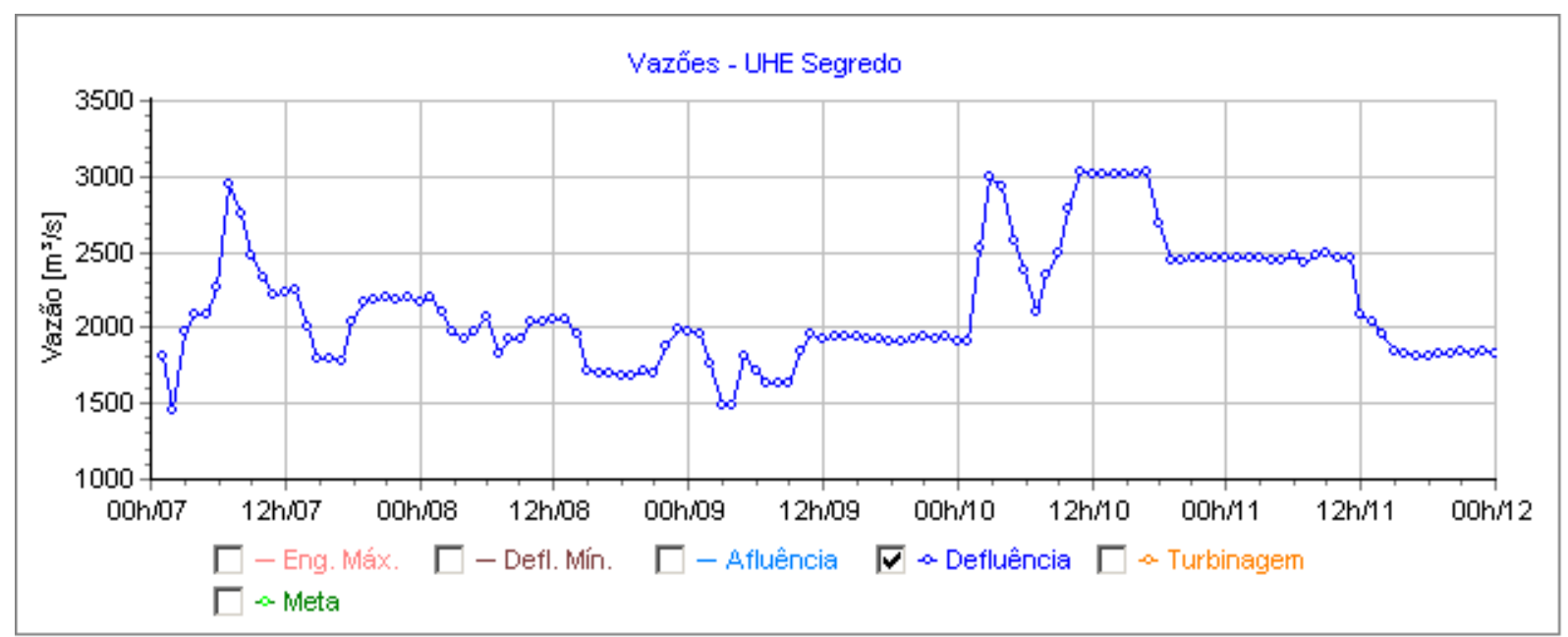

Figura 5.37 - Programação de defluência da UHE Segredo. 


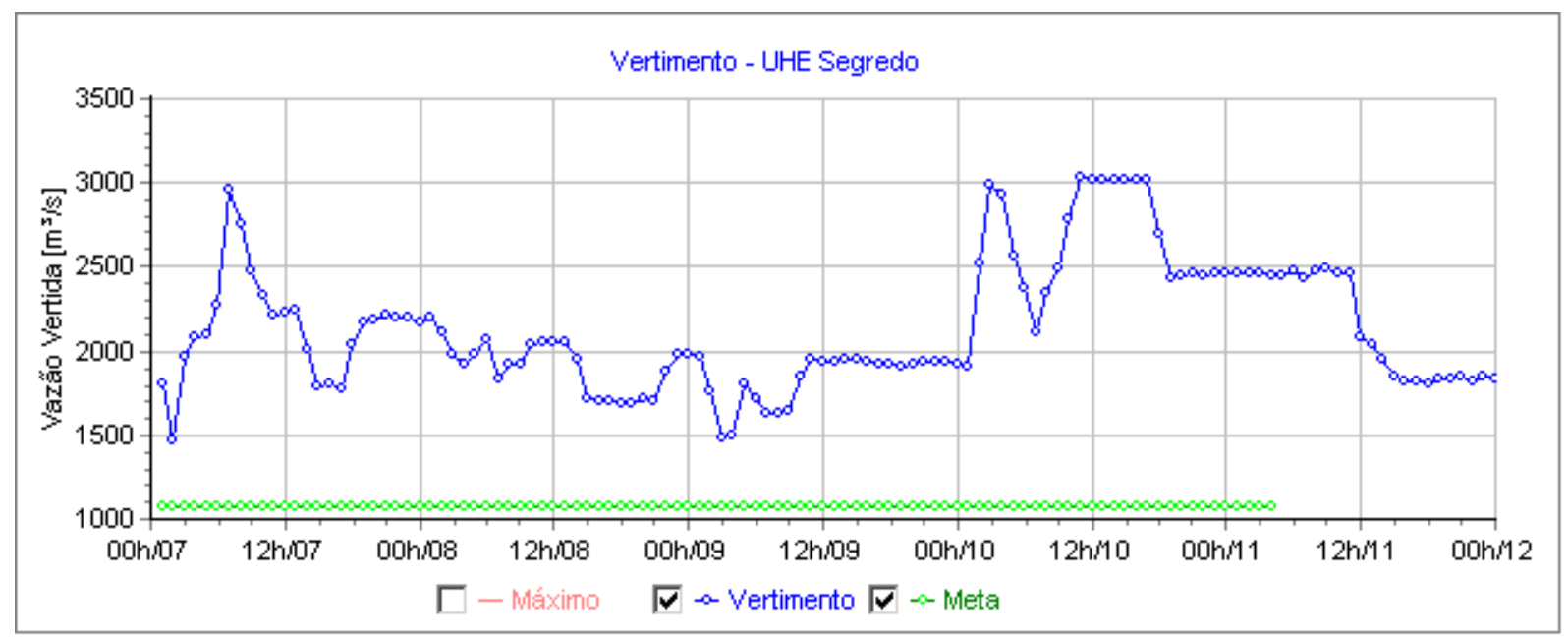

Figura 5.38 - Programação de vertimento da UHE Segredo.

Os resultados das simulações, apresentados no capítulo 5, permitem concluir que a uma vez confirmados os resultados do cálculo do rebaixamento, o módulo rebaixamento transfere caso existam, as vazões vertidas extras calculadas para a ocorrência de deplecionamento antecipado do reservatório. 


\section{CAPÍTULO 6}

\section{CONCLUSÕES E PROPOSTAS DE TRABALHOS FUTUROS}

\section{1 - CONCLUSÕES GERAIS}

Nesta dissertação foi apresentada a problemática do aumento da vazão afluente em um determinado reservatório com a iminência de ocupação do volume vazio, sendo utilizada uma técnica de rebaixamento dinâmico. Esta técnica permite antecipar decisões de vertimento frente a um cenário de cheia, promovendo uma redução no nível do reservatório e alocando volumes vazios.

Para dar suporte às análises apresentadas, foi utilizado o simulador HydroExpert e suas ferramentas, com o objetivo de antecipar o rebaixamento de um reservatório quando o volume de água excedente que chega nele é superior ao volume vazio entre o armazenamento atual e o volume máximo operativo. Dessa maneira, obtém-se um volume vazio no reservatório rebaixado e, assim, torna-se possível o armazenamento de um grande volume de água, sem causar danos a outros aproveitamentos.

No procedimento de rebaixamento dinâmico, foram simulados casos na bacia do rio Iguaçu. A metodologia aplicada a aproveitamentos desta bacia destacou estudos relativos aos reservatórios das UHEs Foz do Areia, Segredo e Salto Santiago.

Uma vez confirmados os resultados do cálculo do rebaixamento, constatou-se que quando o volume excedente for superior ao volume vazio alocado no reservatório, são calculadas vazões vertidas extras prevendo a ocorrência do deplecionamento antecipado do reservatório. Outro fato relevante verificado foi que a vazão defluente deve garantir que o reservatório não fique acima de seu nível máximo operacional durante o período de rebaixamento.

Em função disso, destaca-se a importância da previsibilidade das vazões, utilizando o simulador hidráulico com o objetivo de antecipar um rebaixamento de um reservatório e, assim, garantir o armazenamento de um grande volume de água sem causar danos a outros aproveitamentos. 


\subsection{SUGESTÕES PARA TRABALHOS FUTUROS}

Em função das conclusões descritas acima, recomenda-se em trabalhos futuros a avaliação de estudos com outras bacias hidrográficas. Com este objetivo, torna-se necessário uma adequada modelagem dos aproveitamentos específicos de interesse permitindo uma antecipação de decisões que proporcionam um maior conforto operativo aos Agentes de Geração e ao ONS. Este procedimento é uma ferramenta adicional que permite maior gerenciamento operativo, podendo ser útil para revisão de procedimentos já efetuados. Assim, ser usado como uma ferramenta de possíveis correções de ações previamente previstas para serem executadas.

Outra proposta de trabalho futuro é a análise de caso para o procedimento de recuperação dinâmica. Neste caso, deve-se promover a recuperação do armazenamento. A recuperação deverá levar em conta o efeito de uma curva de recessão crítica nas afluências. Deve-se lembrar que no estudo deve ser fornecida uma previsão de vazões incrementais. Da mesma forma, para qualquer cenário de afluências mais favoráveis, espera-se que o reservatório tenha uma recuperação antecipada do que no cenário de previsão. Este estudo de caso pode ser realizado em qualquer bacia do SIN. 


\section{REFERÊNCIAS BIBLIOGRÁFICAS}

ARCE, A. S., SOARES, S., OHISHI T, 2002 - Optimal Dispatch of Generating units of the Itaipu Hydroelectric Plant. IEEE Transactions on Power Systems.

BALLINI R, 2000 - Previsão de vazões através de Sistemas Neuro-Fuzzy. Tese de Doutorado. FEEC/UNICAMP, setembro.

CHESF, 2001 - "Modelo de simulação energética do Norte/Nordeste".

CICOGNA M. A. e SOARES, S, 1999 - Modelo de planejamento da Operação Energética de Sistemas Hidrotérmicos a Usinas Individualizadas Orientado por Objetos. Anais do XIII SBRHSimpósio Brasileiro de Recursos Hídricos, Belo Horizonte.

CICOGNA M. A. e SOARES, S, 2001 - Assessment of Secondary Energy in Hydroelectric Systems. Proceedings of the 4th Internacional Conference on Hydropower Development, Bergen, Norway, 55-60.

CICOGNA M. A., ARCE, A. S., SANTOS, E.F., SOARES FILHO, S. e OHISHI, T, 2002 - Um critério de Desempenho para o Despacho Ótimo de Unidades Geradoras. Anais do III SEPOCH- Simpósio de Especialistas em Operação de Centrais Hidrelétricas, Foz do Iguaçu.

CICOGNA M. A., SOARES, S, 2002 - Um Sistema Gerenciador de Dados Cadastrais de Usinas Hidrelétricas Brasileiras. Anais do III SEPOCH- Simpósio de Especialistas em Operação de Centrais Hidrelétricas, Foz do Iguaçu.

CICOGNA M. A., SOARES, S, 2003 - Um Sistema de Suporte á Decisão para o Planejamento da Operação de Sistemas Hidrotérmicos de Potência. Anais do XXXV SBPO- Simpósio Brasilieiro de Pesquisa Operacional, Natal.

CICOGNA M. A., SOARES, S, 2003 - Um Sistema de Suporte à Decisão para o Planejamento e a Programação da Operação de Sistemas Hidrotérmicos de Potência. Anais do XVII SNPTEE Seminário Nacional de Produção e Transmissão de Energia Elétrica, Uberlância.

CICOGNA M. A., SOARES, S, 2003 - Um Sistema Gerenciador de Dados Cadastrais de Usinas Hidrelétricas Brasileiras. Anais do XV SBRH- Simpósio Brasileiro de Recursos Hídricos, Curitiba.

CICOGNA M. A., SOARES, S, 2004 - An Objected-Oriented Hydrothermal Scheduling Algorithm. Artigo Submetido ao Power Industry Computer Applications Conference.

CICOGNA M. A., SOARES, S, 2004 - Decision Support System for Hydrothermal Sheduling Algorithm. Artigo Submetido ao Elsevier's Jounal of Computer Applications Conference. 
CICOGNA M. A., SOARES, S. e KADOWAKI, M,. BALLINI, R, 2002 - Previsão de Vazões Médias Mensais: Uma Aplicação para as usinas do Rio Paranapanema. Anais do I CITENEL - Primeiro Congresso de Inovação Tecnológica em Energia Elétrica, Brasília.

CICOGNA M. A, 1999 - Modelo de planejamento da Operação Energética de Sistemas Hidrotérmicos a Usinas Individualizadas Orientado por Objetos. Dissertação de Mestrado. FEEC/UNICAMP.

CICOGNA M. A, 2009 - "Multireservoir Simulation Using Multipurpose Constraints and ObjectOriented Software Design." World Environmental \& Water Resources Congress EWRI/ASCE, Kansas City, Missouri, EUA.

CICOGNA M. A, 2009 - "Simulação Multi-Critério da Operação Hidráulica de Reservatórios." XX SNPTEE - Seminário Nacional de Produção e Transmissão de Energia Elétrica, Cigré-Brasil, Recife, Pernanbuco, Brasil.

CICOGNA M.A., D. G. FOnTANE, I. G. HIDALGO, J. E. LOPES - 2009, "Multireservoir Simulation Using Multipurpose Constraints and Object-Oriented Software Desin," Proceedings of the ASCE - World Environmental \& Water Resources Congress (EWRI), p.5030-5040.

CICOGNA M. A., I. G. HIDALGO, J. G. LOPES,2009 - "Simulação Multi-critério da Operação Hidráulica de reservatório," XX SNPTEE - Recife - PE.

CICOGNA M. A.,2003- Sistema de Suporte à Decisão para o Planejamento e a Programação da Operação de Sistema de Energia Elétrica. Tese de Doutorado FEE/UNICAMP.

CICOGNA M. A, 2009 - "Manual do assistente de rebaixamento e recuperação dinâmicos pertencentes ao modelo de simulação HydroSim XP do Sistema HydroExpert”, versão 1.0 atualizada em 2015-01-30, impressão realizada em 2015-03-09.

CICOGNA M. A ,2014 - “Curso HydroExpert - módulo 7 - HydroSim XP - RR Dinâmico”, versão 1.0 - 2014-08-17, impressão realizada em 2015-03-23.

CICOGNA M. A, 2015- "HYDROBYTE SOFTWARE - HydroSim XP: Manual do Usuário,". Disponível em: <www.hydrobyte.com.br>. Acesso em 05 de maio de 2015.

COPEL, 2016 - http://www.copel.com/hpcopel/root/index.jsp. [Página da Web. Acesso em: 18 maio 2016].

CRUZ, Jr. G. \& SOARES S, 1996 - Non-uniform Composite Representation of Hydroelectric Systems for Long-Term Hydrothermal Scheduling. IEEE Transactions on Power. Vol 11, nº 2, pp. $702-$ 707.

CRUZ, Jr. G. \& SOARES S, 1999 - General Composite Representation of Hydroelectric Systems. Power Industry Computer Applications - PICA'99 - Proceedings of the 21st 1999 IEEE International Conference. Pp. 177-182. 
DINIZ, P, 2002 - "A metodologia de adoção e atualização das restrições operativas hidrúalicas dos aproveitamentos hidroelétricos no planejamento eletroenergético: o ONS e a Política Nacional de Recursos Hídricos”. VII Encontro para Debates de Assuntos de Operação.

GUILHON, CICOGNA, 2013 - "Uso do Simulador Hidráulico Hydroexpert na Programação da Operação de Controle de Cheias," Simpósio Brasileiro de Recursos Hídricos, Bento Gonçalves.

DAMÁZIO, J. M. 2001 -“PROGRAMA DIAG: Especificação Técnica,” 18 p., 2001.

GUILHON, C. P. OLIVEIRA, M. ALEXANDRINO, 2010 -“Aplicação do simulador hidráulico Hydroespert à bacia do rio Iguaçu, XI EDAO, Florianopólis, pp. 1-10.

OLIVEIRA A., NEPOMUCENO L. e SOARES S, 2003- Optimal Actice Power Dispatch Combining Network Flow and Interior Point Approaches. IEEE Transactions on Power, vol. 18, nº 4.

OLIVEIRA G. G, 1993 - Otimização da Operação Energética de Sistemas Hidrotérmicos com Representação Individualizada das Usinas e Afluências Determinísticas. Dissertação de Mestrado, FEEC/UNICAMP.

OLIVEIRA G. G. \& SOARES S, 1995. A Second-Order Network Flow Algorithm for Hydrothermal Scheduling. IEEE Transactions on Power Systems, USA, vol. 10, nº 3, pp. 1635-1641.

ONS, 2011 - "Algoritmo FASG - Descrição Técnica do Algoritmo FASG da COPEL implementado no SSD HydroExpert," Projeto ONS/HYDROBYTE.

ONS, 2014 - “Cheia ocorrida na Bacia do Rio Iguaçu em junho de 2014,”. Relatório ONS.

ONS, 2015 - "Diretriz para as regras de Operação de Controle de Cheias - Bacia do Rio Iguaçu (Ciclo 2013 - 2014)".

PEREIRA, 1985 - Optimal Scheduling of Hydrothermal System - An Overviem. IFAC Symposium on Planning and Operation of Eletric Energy Systems, Rio de Janeiro, pp. 1-9.

PEREIRA e PINTO, 1985 - Stochastic Optimization of a Multireservoir Hydroelectric System - A Decomposition Approach. Water Resources Research, vol. 21, nº. 6, pp. 779-792. 


\section{APÊNDICE A}

\section{ENTRADA DA ROTINA DO HYDROEXPERT}

No quadro abaixo, é apresentado o aplicativo Hidroexpert que trata-se de um simulador hidráulico, conectado a uma base de dados técnicos de aproveitamentos hidroelétricos. O software é composto por aplicativos, um banco de dados próprio e permite conexões com banco de dados de outras empresas.

Quadro A.1 - Caixa de entrada do aplicativo HydroExpert

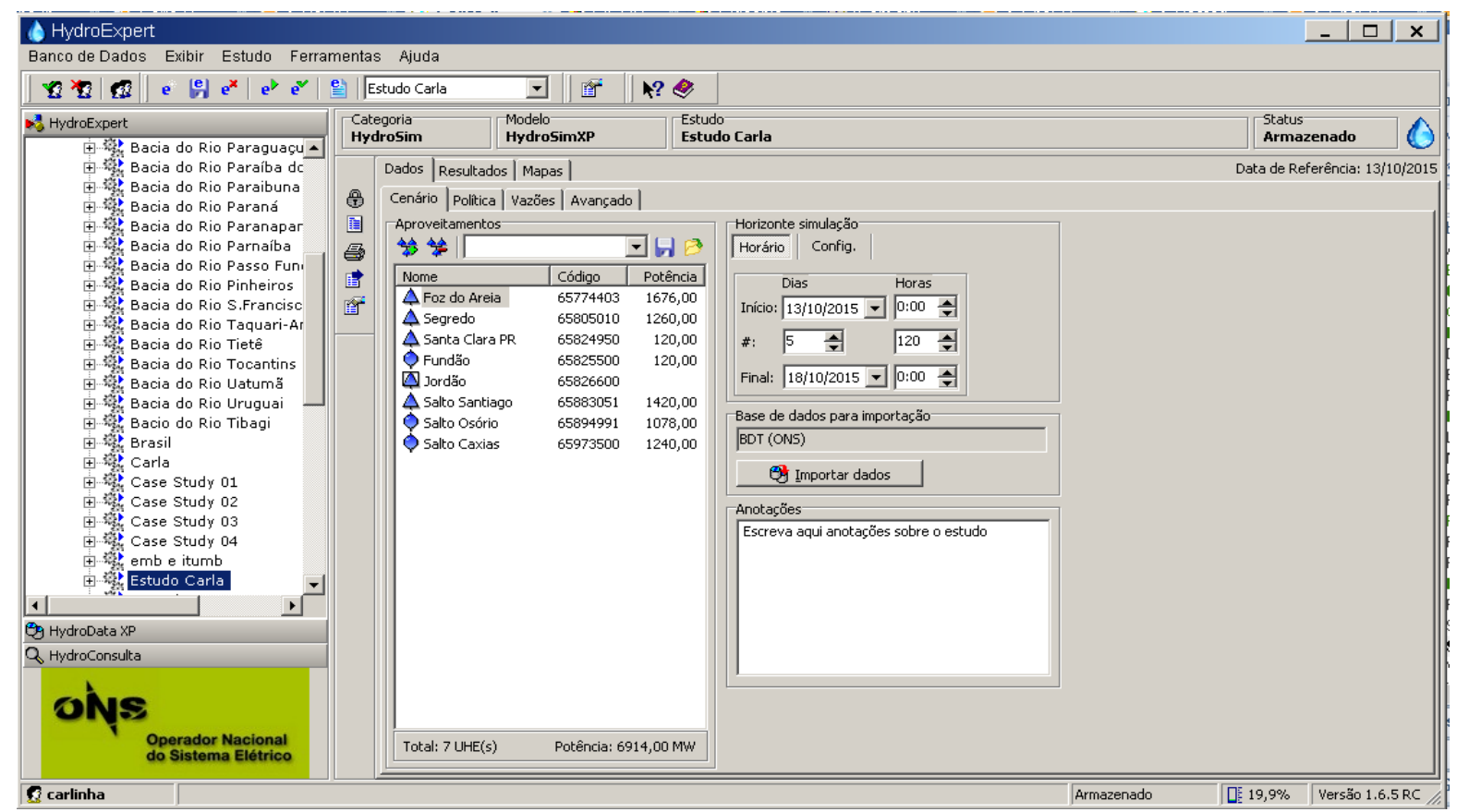


Quadro A.2 - Caixa de entrada do aplicativo HydroExpert do Assistente Rebaixamento/Recuperação

\section{Dinâmico.}

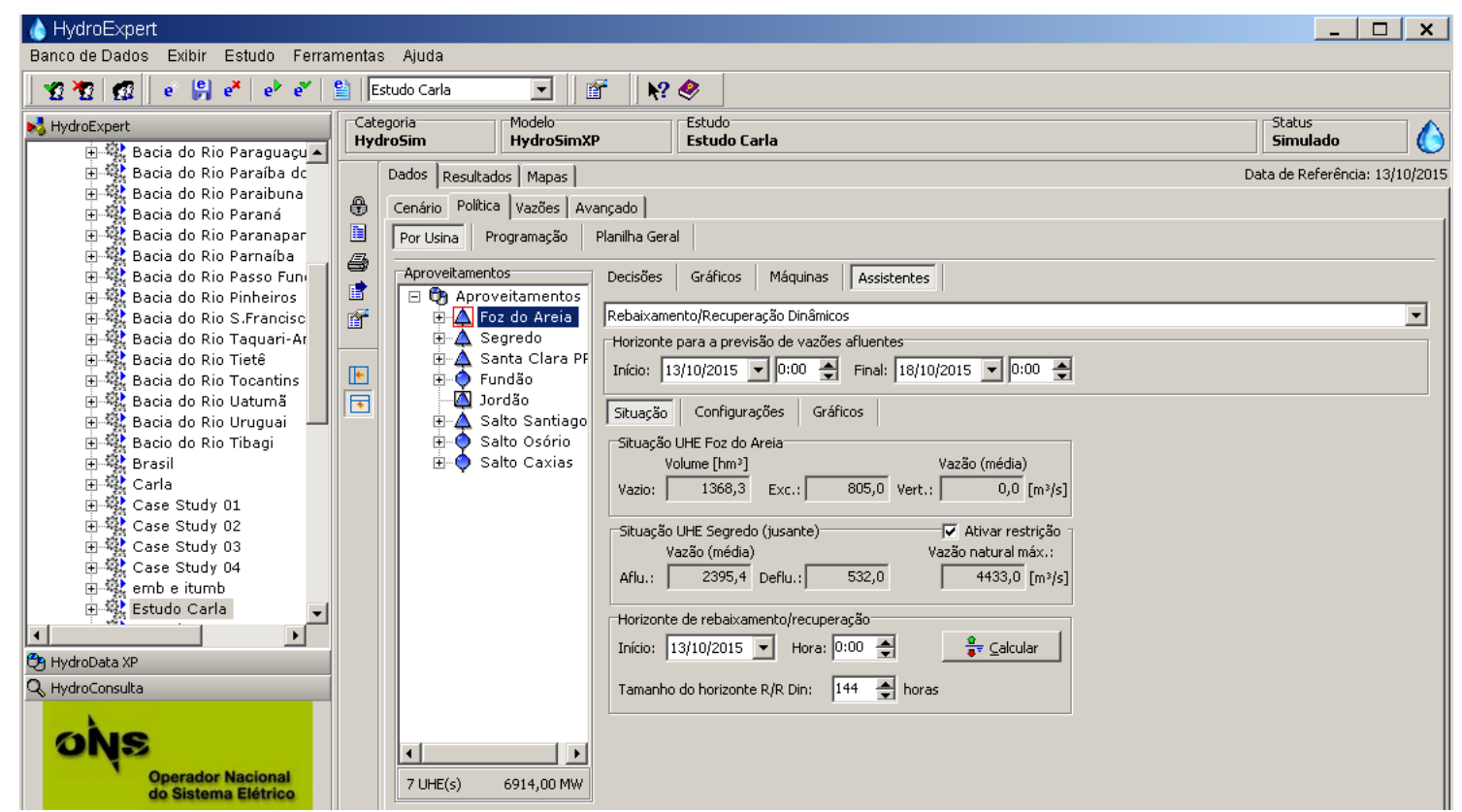

